\title{
Sandstone Composition of the Valdez and Orca Groups, Prince William Sound, Alaska
}

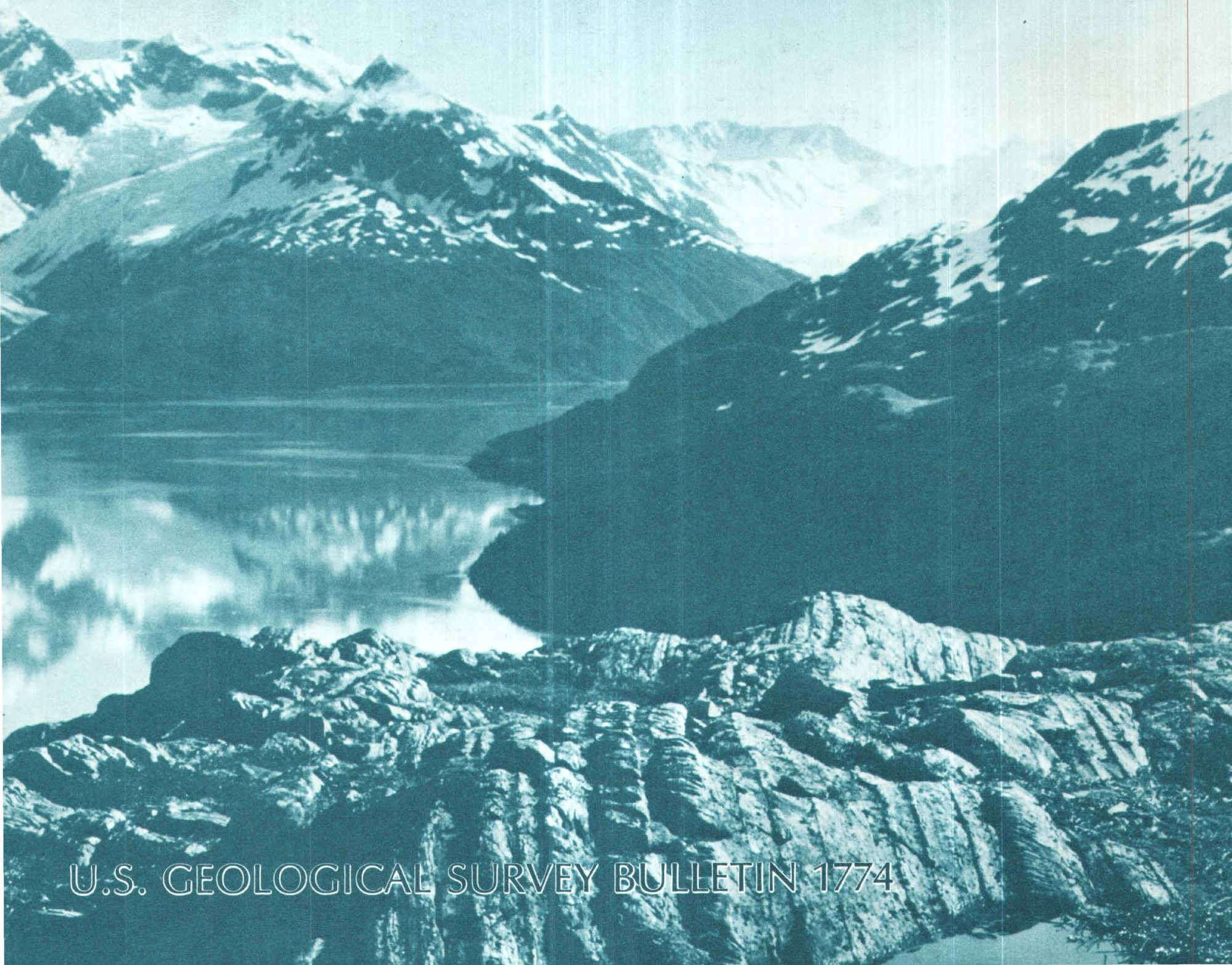




\section{Sandstone Composition of the Valdez and Orca Groups, Prince William Sound, Alaska}

By JULIE A. DUMOULIN 
DEPARTMENT OF THE INTERIOR

DONALD PAUL HODEL, Secretary

U.S. GEOLOGICAL SURVEY

Dallas L. Peck, Director

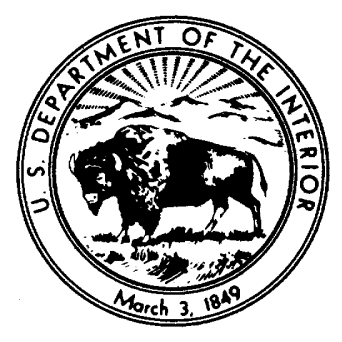

For sale by the

Books and Open-File Reports Section

U.S. Geological Survey

Federal Center, Box 25425

Denver, CO 80225

Library of Congress Cataloging-in-Publication Data

Dumoulin, Julie A.

Sandstone composition of the Valdez and Orca Groups,

Prince William Sound, Alaska.

U.S. Geological Survey Bulletin 1774

Bibliography

1. Sandstone-Alaska-Prince William Sound Region. 2.

Geology, Stratigraphic-Cretaceous. 3. Geology,

Stratigraphic-Tertiary. 4. Valdez Group (Alaska) 5. Orca

Group (Alaska). I. Title. II. Series.

QE75.B9 No. 1774

[QE471.25.S25]

$622 \mathrm{~s}$

$\left[553.5^{\prime} 3\right]$

$87-600307$ 


\section{CONTENTS}

Abstract 1

Introduction 1

Acknowledgments 2

General geology 2

Valdez Group and correlative rocks 2

Orca Group and correlative rocks 5

The Contact fault system $\mathbf{5}$

Previous petrographic studies 7

Methodology 8

Results of studies of Valdez Group samples 8

West, central, and east Valdez areas $\mathbf{8}$

Differences between west Valdez- and central Valdez-area samples 10

Provenance 12

Anomalous Valdez Group samples 13

Results of studies of Orca Group samples 14

Eastern exposures of the Orca Group 14

Western exposures of the Orca Group 19

Anomalous Orca Group samples 22

Comparison of results of studies of the Orca Group with previous work $\mathbf{2 5}$

Tectonic models and the placement of the Valdez-Orca boundary 25

Evidence for the northward displacement of the Valdez and Orca Groups $\mathbf{2 6}$

Petrographic constraints on the significance and location of the Valdez-Orca boundary

The existence of a terrane boundary 27

Alternative locations of a terrane boundary 27

Johnstone Bay fault 27

Bainbridge fault $\mathbf{2 8}$

Montague Strait fault $\mathbf{2 8}$

Placer River fault $\mathbf{2 8}$

Imbricate faulting along terrane boundary 28

Summary 28

Areas that have anomalous sandstone petrography Mount Denson area

Areas spatially associated with mafic rocks 29

Resurrection Peninsula area 29

Knight Island area $\mathbf{3 0}$

Ellamar area $\mathbf{3 0}$

Montague Island and Ragged Mountain areas

Petrography $\mathbf{3 1}$

Age 31

Metamorphic-grade relationships $\mathbf{3 3}$

Structural style $\mathbf{3 4}$

Sedimentary facies $\mathbf{3 4}$

Conclusions $\mathbf{3 4}$

References cited $\mathbf{3 4}$

\section{FIGURES}

1. Generalized geologic-tectonic setting of the Prince William Sound area, Alaska.

Terrane boundaries 2

2. Geologic map of the Prince William Sound area 3

3. Turbidites of the Valdez Group in the Port Wells area, western Prince William Sound 4

4. Fossil localities and location of Valdez Group-Orca Group contact in western Prince William Sound as delineated by previous workers 6 
5. Location of petrographic areas and samples point-counted for this study 7

6. Modal analyses of sandstone of the Valdez Group from the west Valdez, east Valdez, and central Valdez areas 10

7. Photomicrographs in transmitted light of thin sections of sandstones from the Valdez Group 11

8. Modal analyses of sandstone from the Valdez Group and (at least partly) correlative lithostratigraphic units 12

9. Modal analyses of sandstone of the Valdez Group from the Mount Denson and Resurrection Peninsula areas compared with analyses of sandstone of the Orca Group from the Port Gravina-Cordova area 15

10. Modal analyses of sandstone of the Valdez Group from the Mount Denson and Resurrection Peninsula areas compared with those from the west Valdez, central Valdez, and east Valdez areas $\mathbf{1 6}$

11. Modal analyses of sandstone of the Orca Group from the Port Gravina and Cordova areas compared with analyses of sandstone of the Orca Group from the Hinchinbrook Island area 17

12. Photomicrographs in transmitted light of thin sections of sandstones from the Orca Group 18

13. Modal analyses of sandstone of the Orca Group from the Sargent Icefield and Chenega areas compared with analyses of the Ghost Rocks Formation $\mathbf{2 0}$

14. Comparison of sandstone modal analyses from the Valdez and Orca Groups $\mathbf{2 1}$

15. Modal analyses of sandstone of the Orca Group from the Ellamar and Knight Island areas 23

16. Comparison of modal analyses of sandstone from the Knight Island-Ellamar (combined), Montague Island, and Ragged Mountain areas with those from the Port Gravina-Cordova area $\mathbf{2 4}$

17. Modal analyses for sandstone of the Orca Group from the Montague Island and Ragged Mountain areas compared with analyses from the Zodiac fan and from the Sitkalidak Formation $\mathbf{3 2}$

18. Ratio of volcanic clasts to total lithic fragments in Zodiac fan sediment, Sitkalidak Formation sandstone, and Orca Group sandstone from the Montague Island and Ragged Mountain areas $\mathbf{3 3}$

\section{TABLES}

1. Composition of sandstone from the west Valdez, east Valdez, and central Valdez areas 9

2. Geochemical analyses of selected Valdez and Orca Group sandstone samples 13

3-5. Composition of sandstones:

3. From the Valdez Group: Mount Denson and Resurrection Peninsula areas 14

4. From the Orca Group: Cordova and Port Gravina areas 16

5. From the Orca Group: Sargent Icefield and Chenega areas 19

6. Statistical summary of first-degree trend surface for point-count data 21

7-8. Composition of sandstones:

7. From the Orca Group: Knight Island and Ellamar areas $\mathbf{2 2}$

8. From the Orca Group: Montague Island and Ragged Mountain areas 31 


\title{
Sandstone Composition of the Valdez and Orca Groups, Prince William Sound, Alaska
}

\author{
By Julie A. Dumoulin
}

\section{ABSTRACT}

The contact between the Upper Cretaceous Valdez Group and the Paleocene and Eocene Orca Group has been interpreted as a major boundary between the Chugach and the Prince William tectonic terranes. Petrographic analyses of sandstone present in the Prince William Sound area, however, reveal no sharp compositional break across this contact.

In the western part of the Prince William Sound area, compositions of both groups change systematically from west to east. No abrupt change occurs at the Contact fault system, which juxtaposes the two groups; ternary plots and discriminant analysis cannot distinguish sandstone of the easternmost part of the Valdez Group (east of the Placer River fault) from that of the westernmost part of the Orca Group (Sargent Icefield area).

Valdez Group sandstone west of the Placer River fault contains abundant volcanic lithic clasts, and lathwork textures predominate over felsitic textures; mean $Q-F-L$ is $15.5-35-49.5$. East of the Placer River fault, sandstone of both groups becomes progressively richer eastward in quartz, potassium feldspar, and plagioclase, and progressively poorer eastward in lathwork-textured volcanic clasts. Trend-surface analysis indicates that these changes are statistically significant at the 99 percent confidence level $(95$ percent level for plagioclase). The composition of the eastern part of the Orca Group (Cordova-Port Gravina area) is more nearly homogeneous; average $Q-F-L$ is 27-57-16, and lithic clasts are mostly volcanic. The QF-L and Qp-Lv-Ls plots of point-count data indicate a dominantly magmatic-arc provenance for sandstones of both groups, with continued erosion from the volcanic cover to the plutonic roots of the arc through time.

The petrographic data for these sandstones are best explained by assuming that there is no terrane boundary in western Prince William Sound, and that the Valdez and Orca Groups form a single flysch sequence derived from one progressively unroofing source in Late Cretaceous and Paleogene time. The magmatic arc of the Peninsular terrane represents one possible source. If a major terrane boundary does exist in western Prince William Sound, sandstone petrographic data indicate that it is most likely to lie along the Bainbridge fault, $50 \mathrm{~km}$ east of the Contact fault. The Bainbridge fault marks the most striking petrographic discontinuity found in this study-it separates the quartz-rich rocks of the Knight Island area $(\mathrm{Q}-\mathrm{F}-\mathrm{L}=51-31-18)$ from the more feldspathic rocks of the Chenega area $(Q-F-L=27-51-22)$.

Several regions of anomalous sandstone composition are delineated by this study. Sandstone of the Mount Denson area, currently assigned to the Valdez Group, contains significantly more quartz and feldspar clasts than do other sandstones of the Valdez Group, and is modally similar to Orca Group sandstone (mean Q-F-L $=28-60-12$ ). Sandstone spatially associated with volcanic rocks--in the Resurrection Peninsula area (currently assigned to the Valdez Group) and in the Knight Island and Ellamar areas (currently assigned to the Orca Group)-is relatively rich in quartz and feldspar. The Qp-Lv-Ls plots indicate the presence of an important subductioncomplex component in the provenance of these rocks, but their anomalous compositions may also reflect barrier effects of local volcanic edifices. Sandstone of the Montague Island and Ragged Mountain areas, currently assigned to the Orca Group, is rich in quartz and sedimentary lithic clasts (Montague area mean Q$F-L=41.5-34.5-24)$. These rocks show similarities in petrography age, metamorphic grade, structural style, and sedimentary facies, to the Sitkalidak Formation, $400 \mathrm{~km}$ to the west, as well as petrographic similarities to the sediments of the Zodiac fan.

\section{INTRODUCTION}

D.L. Jones and his coworkers have suggested that the contact between the Upper Cretaceous Valdez Group and the Paleocene and Eocene Orca Group represents a major terrane boundary. For example, Jones and others (1981) and Silberling and Jones (1984) used this contact as the boundary between the Chugach and Prince William terranes (fig. 1). However, the placement of the Valdez-Orca contact has long been a source of controversy. This is especially true in western Prince William Sound, where the regional strike of the two groups is parallel and fossil data are sparse. Preliminary petrographic investigations (Mitchell, 1979; Winkler, 1976) suggested that the sandstone composition of the Valdez Group and its lateral equivalents is distinct from that of the Orca Group. The present study was undertaken in order to characterize the sandstone composition of the two groups throughout the Prince William Sound area and particularly to test whether a 
significant change in sandstone composition may help define the placement of the contact between the Valdez and Orca Groups.

\section{ACKNOWLEDGMENTS}

This study was part of a survey of the geology and mineral resources of the Chugach National Forest, conducted under the auspices of the second Roadless Area Review and Evaluation (RARE II). I particularly acknowledge the many important contributions of my Chugach RARE II colleagues S.W. Nelson and M.L. Miller, U.S. Geological Survey. I also thank R.J. Goldfarb, U.S. Geological Survey, for his statistical analysis of the sandstone point-count data, and R.G. Tysdal and S.H.B. Clark, both of the U.S. Geological Survey, for the loan of thin sections from western Prince William Sound.

\section{GENERAL GEOLOGY}

\section{Valdez Group and Correlative Rocks}

The Valdez Group comprises part of a belt of Cretaceous and Jurassic accretionary rocks more than $2000 \mathrm{~km}$ long and as much as $100 \mathrm{~km}$ wide that extends along the Alaska coastal margin from Baranof Island on the east to the Sanak and Shumagin Islands on the west (Plafker and others, 1977) (fig. 1). It is composed primarily of flysch deposits with volumetrically minor intercalations of mafic intrusive and volcanic rocks (figs. 2 and 3 ).

This belt has been called the Chugach terrane (Jones and others, 1981), and it is separated from the Peninsular terrane to the north by the Border Ranges fault system. It consists of a discontinuous-landward melange facies and a continuous-seaward flysch facies.
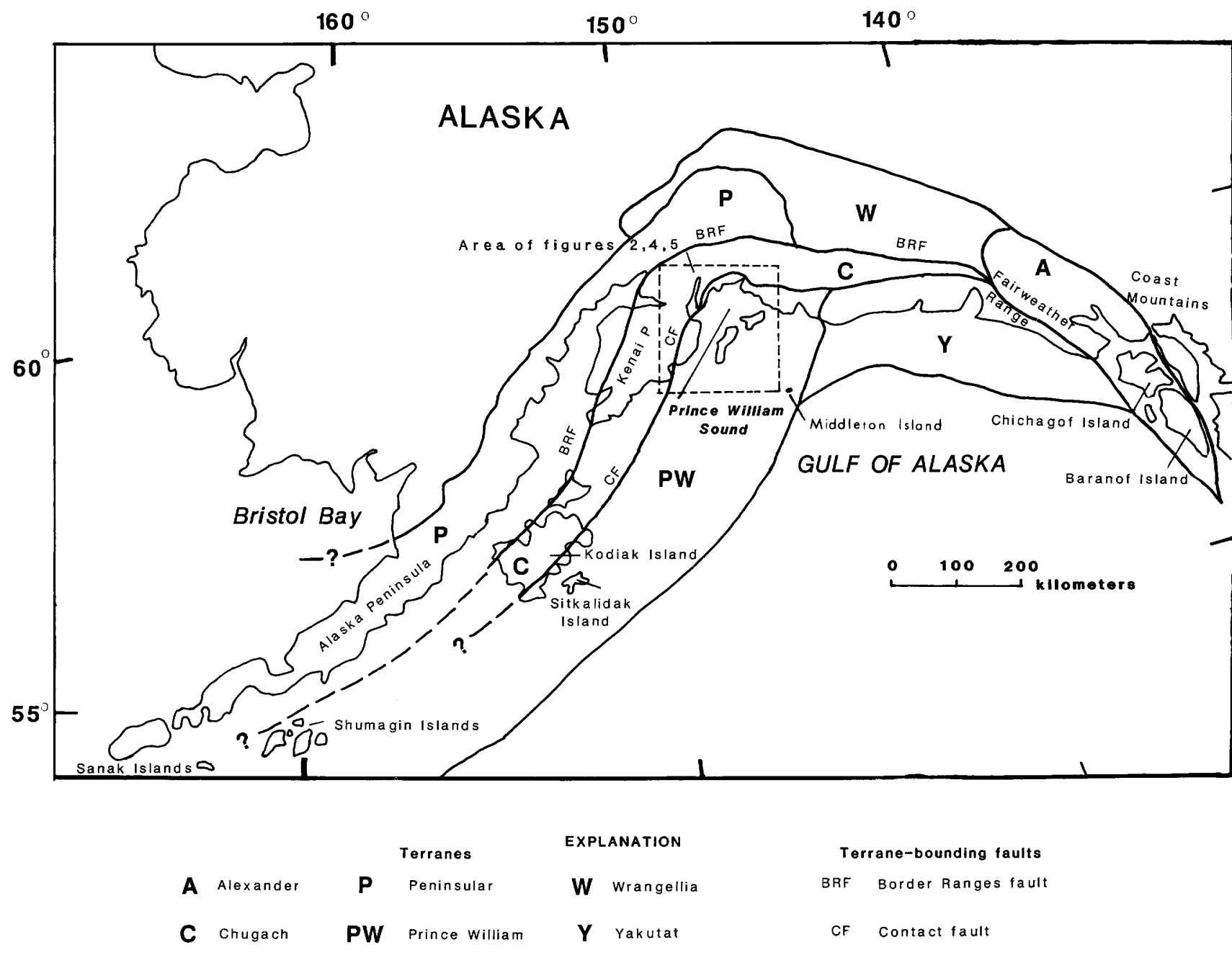

Figure 1. Generalized geologic-tectonic setting of the Prince William Sound area, Alaska. Terrane boundaries generalized from Jones and others, 1981; Silberling and Jones, 1984. 
In the Prince William Sound area, the melange facies is known as the McHugh Complex. Generally correlative rocks to the west are the Uyak Complex (Kodiak area) and the Seldovia Bay Complex (southern Kenai Peninsula); to the east, generally correlative rocks are the melange facies of the Yakutat Group and, in the Chichagof Island area, the Kelp Bay Group. Paleontologic ages of the matrix of the melange facies range from Jurassic to Late Cretaceous (Nelson and others, 1986); paleontologic and radiometric ages of slabs and blocks in the melange range from late Paleozoic to Late Cretaceous. (See summary in Winkler and others, 1984.)

The melange facies is separated from the flysch facies by the Eagle River and related faults. Valdez Group is the name assigned to the flysch facies that extends from the southern margin of the Kenai Peninsula eastward to Chichagof Island (fig. 1). Correlative rocks to the southwest are the Kodiak and
Shumagin Formations. Rocks in southeastern Alaska that are probably correlative include the Sitka Graywacke, particularly the Ford Arm unit of Decker (1980), and part of the Yakutat Group.

The flysch facies of the Chugach terrane consists of slope, fan, and basin-plain deposits and has a dominantly magmatic-are provenance (Zuffa and others, 1980). Flysch deposition was apparently confined to a trench in which sediment transport was dominantly westward (Nilsen and Zuffa, 1982).

In general, the Valdez Group is folded and deformed, and it is metamorphosed to grades ranging from laumontite to amphibolite (or hornblende hornfels) facies (Nelson and others, 1985). Laumontite- to mid-greenschist-facies rocks dominate in the western part of the study area; the eastern part contains mainly mid- to upper-greenschist facies, with the development of amphibolite facies locally north of Port Fidalgo and in a larger area east of the Copper River (Hudson and Plafker, 1982; Goldfarb and others,

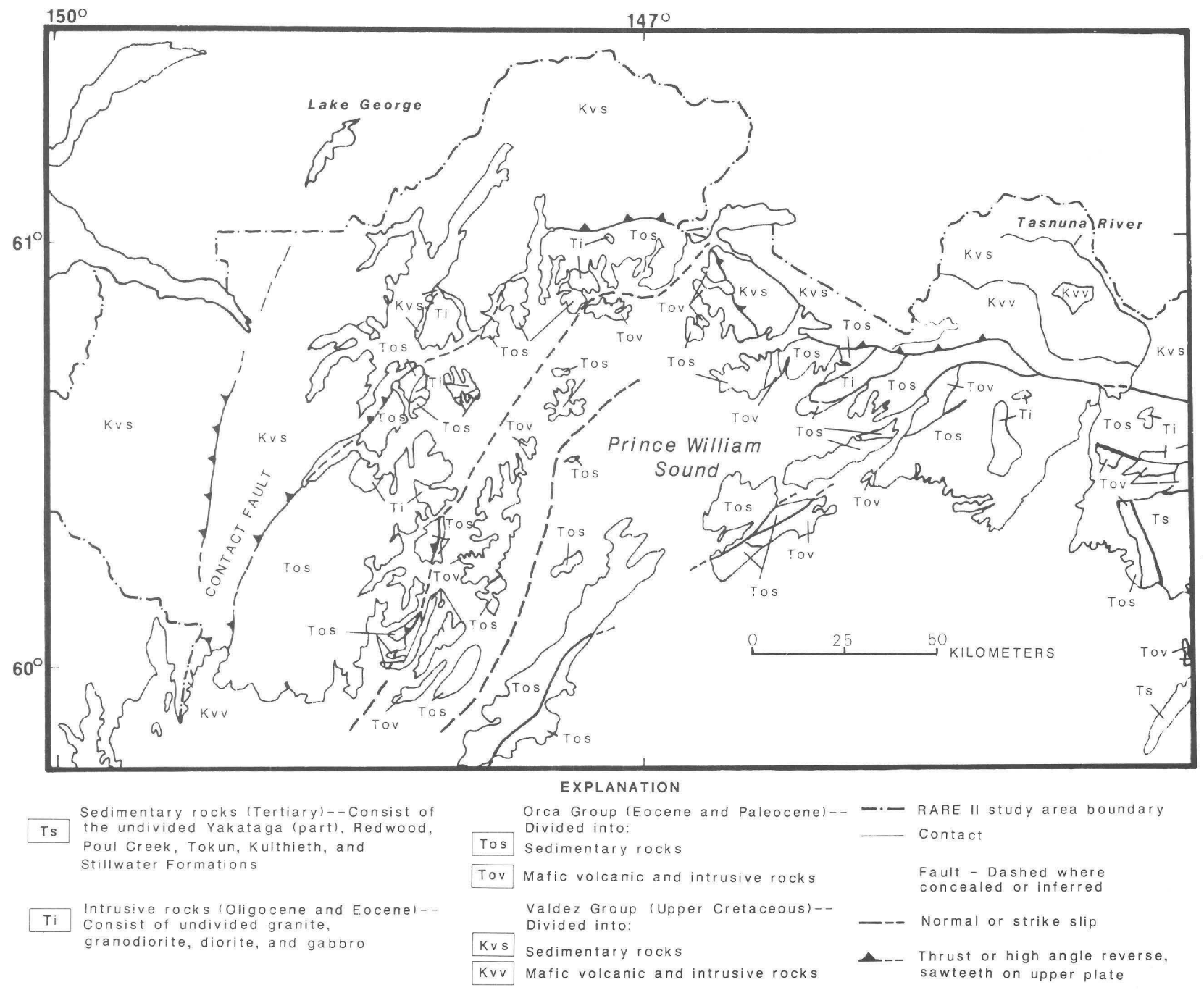

Figure 2. Geologic map of the Prince William Sound area, simplified and slightly modified from Nelson and others (1985). See figure 1 for location. 


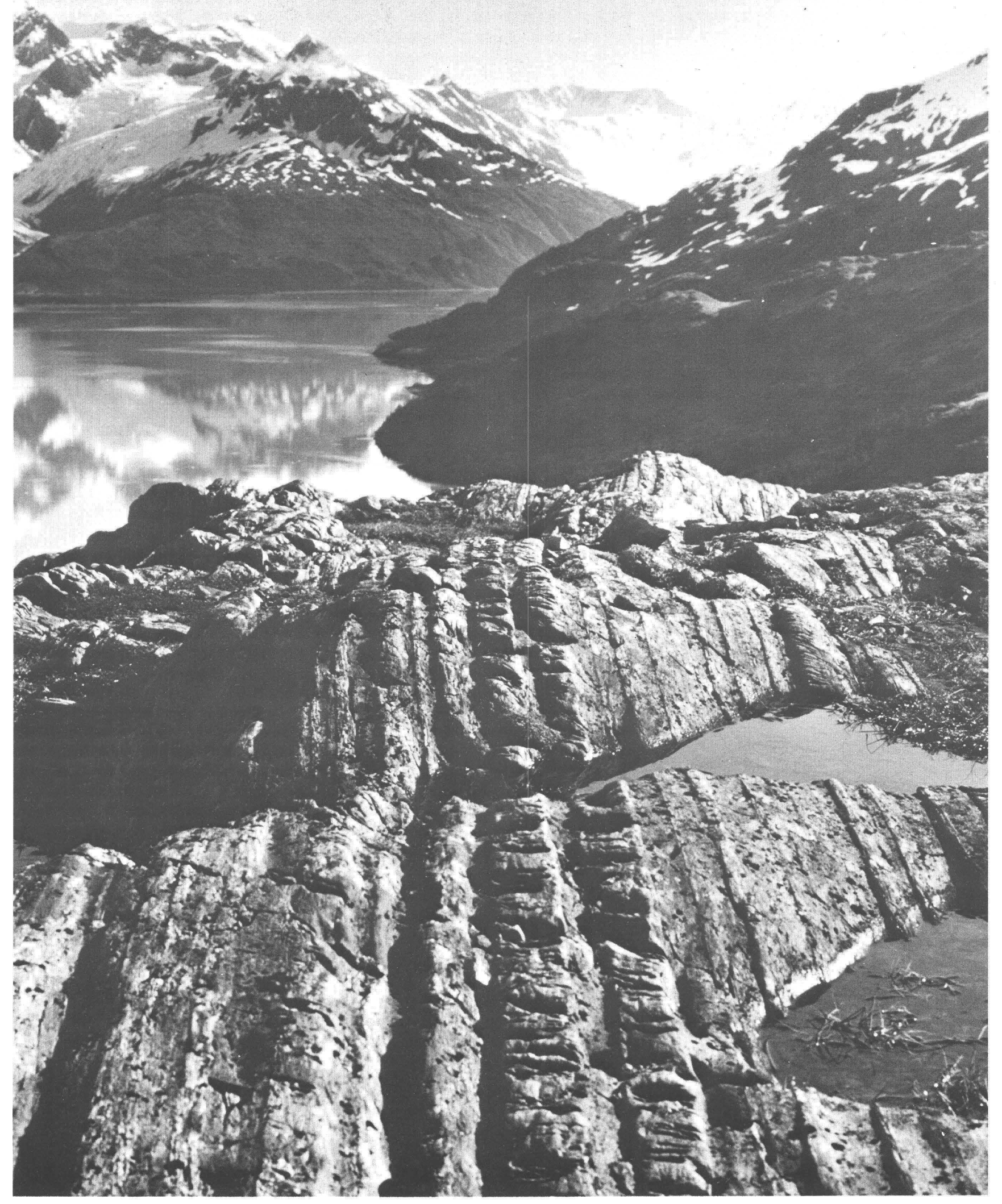

Figure 3. Turbidites of the Valdez Group in the Port Wells area, western Prince William sound. Width of outerop is about $3 \_$m. Photograph by Marti L. Miller, U.S. Geological Survey. 
1986; Sisson and others, 1986). The Late Cretaceous age of the group is based on a few widely scattered Campanian(?) and Maestrichtian pelecypods (Jones and Clark, 1973).

\section{Orea Group and Correlative Rocks}

The Orca Group also consists predominantly of flysch deposits, with subordinate intercalations of mafic intrusive and volcanic rocks. It too is part of an accretionary belt, of Paleogene age, that extends through Prince William Sound to the Kodiak Islands to the west and probably underlies much of the contiguous continental shelf (Plafker 1969, 1971; Tysdal and Case, 1979). Laterally equivalent rocks in the Kodiak-Sitkalidak Islands are the Paleocene Ghost Rocks Formation of Moore and others (1983) and the Eocene Sitkalidak Formation of Moore and Allwardt (1980). This accretionary belt is considered by Jones and others (1981) to constitute the Prince William terrane, separated from the Chugach terrane to the north by the Contact fault system.

The Orca Group in Prince William Sound represents middle (and possibly inner) submarine-fan deposits (Winkler, 1976; Nelson and others, 1985). Correlative rocks to the west include abyssal-plain, slope, slope-basin, or forearc-basin deposits (Moore and others, 1983).

Like the Valdez Group, the Orca Group has been folded and deformed and has reached metamorphic grades of laumontite to upper-greenschist facies, with local development of amphibolite (or hornblende hornfels) facies (Nelson and others, 1985; M.L. Miller, written commun., 1985). The lowest grade rocks form a northeast-southwest-trending belt that includes Montague and Hinchinbrook Islands; metamorphic grade increases to the north and the northwest. In general, the Orca Group shows prehnite-pumpellyite to lower-greenschist facies, with the highest grade rocks occuring in three situations: (1) as aureoles around plutons, (2) near faults, and (3) on a more regional scale, east of the Copper River (Goldfarb and others, 1986; M.L. Miller, written commun., 1985).

Sparse microfossil and megafossil assemblages have been recovered from the Orca Group (Plafker and others, $1985 \mathrm{a}$ and b). Northern exposures of the group are intruded by a belt of granitic, granodioritic, and tonalitic plutons; $\mathrm{K} / \mathrm{Ar}$ ages on mineral separates from these plutons range from 50.5-53.5 \pm 1.6 Ma (Plafker and Lanphere, 1974). Plafker and others (1985b) maintained that the combined paleontologic and radiometric data constrain the age of the Orca Group to the late Paleocene through the early middle Eocene. However, "the lower age range of the unit is not known" (Plafker and others, 1985b, p. 74) and no data exist that would preclude an early Paleocene age for parts of the Orca Group. The upper age limit of the Orca Group is interpreted by Plafker and others $(1985 \mathrm{~b})$ to be the emplacement age of the late early to earliest middle Eocene plutons, but these plutons do not intrude southeastern exposures of the Orca Group (Montague and Hichinbrook Islands, Ragged Mountain). Futhermore, these southeastern exposures contain microfaunas of middle and late Eocene age (Plafker and others, 1985a) (fig. 4). Therefore, in this report, the age of the Orca Group is considered to be Paleocene through Eocene.

\section{The Contact Fault System}

The Orca Group is separated from the Valdez Group to the north by the Contact fault, which includes the Bagley, Gravina, and Landlock fault segments in the Cordova quadrangle (Winkler and Plafker, 1981) (fig. 5). Both the Orca and Valdez Groups are cut by numerous large-scale faults. Because of the similarity of the lithology and, locally, the metamorphic grade of the two groups, and the paucity of fossils obtained from either group, the placement of the boundary between them has been difficult to locate. This is particularly true in the western part of Prince William Sound, where the regional strike of the two groups is parallel.

Early workers originally assigned to the Orca Group rocks of the islands east of Bainbridge and Knight Island Passages, the rocks of Naked and Glacier Islands, and rocks of the mainland adjacent to Orca Bay, Port Gravina, and Port Fidalgo (Grant and Higgins, 1910) (fig. 4). Moffit (1954) included the rocks of eastern Chenega Island in the Orca Group, but he assigned the rocks of western Bainbridge Island and the west side of Valdez Arm to the Valdez Group. He stated, however, that "the Orca Group *** cannot yet be clearly differentiated from the Valdez Group" (p. 248) and "the longer the work has gone on, the less certain appears to be the distinction" between the two groups (p. 240).

At the time of Moffit's work, available fossil data fostered the belief that the two groups were of the same (Mesozoic) age; with this and the lithologic similarity of the two groups in mind, Moffit (1954) pointed out the desirability of discontinuing the use of the two names. After the discovery of crabs and pelecypods of Paleogene age north of Galena Bay (Plafker and MacNeil, 1966), the idea that the two sequences were separated on the basis of age was revived. Plafker and others (1977) placed the OreaValdez contact in western Prince William Sound about $25 \mathrm{~km}$ west of the boundary Moffit had used (fig. 4)close to what is now called the Johnstone Bay faultseparating rocks assigned a Cretaceous age (Valdez Group) from those assigned a Paleogene age (Orca Group).

Tysdal and Case (1979) placed the contact another $25 \mathrm{~km}$ to the west, claiming that they were not able to distinguish a stratigraphic break along the trend Plafker and others (1977) used as the contact. The contact delineated by Tysdal and Case is now called the Contact fault. Although Tysdal and Case (1979) stated that in the northern part of the Seward quadrangle this structure is a major fault zone (with a trace of sheared and fractured rock $2-4 \mathrm{~km}$ wide), they added that "the intensity of deformation along the fault zone decreases from north to south" (p. 10). South of Wells Passage, rocks of the same metamorphic grade "occur on both sides of the fault zone, and the exact location of the fault is difficult to define" (Tysdal and Case, 1979, p. 10).

Thus, the area in western Prince William Sound where rocks have been variously assigned to both the 
Orca and Valdez Groups by previous workers encompasses a belt about $50 \mathrm{~km}$ wide between the Contact fault of Tysdal and Case (1979) and the trend of the Bainbridge and Knight Island Passages. This large area has so far yielded no age-specific fossil assemblages, so the rocks cannot be assigned to either the Orca or Valdez Groups on this basis. The most easterly fossil collected in this part of the Valdez Group is a pelecypod of Late Cretaceous age found in float near Point Cochrane (fig. 4), along the southwestern shore of Port Wells. The most westerly fossil assemblage in the Orca Group consists of poorly preserved foraminifers from Bear Point, identified as probably Tertiary in age (Tysdal and Case, 1979).

Lithologically, the area between the Contact fault of Tydsal and Case (1979) and the trend of the Bainbridge and Knight Island Passages is, in large part, distinct from adjacent rocks of either the Orca or the
Valdez Groups. Much of the area consists of a belt of massive sandstone referred to by Helwig and Emmet (1981) as the Blying Sound belt. Earlier workers (Moffit, 1954; Tysdal and Case, 1979) also recognized the distinctive character of these rocks. On trend with this belt of massive sandstone in the Unakwik Inlet area (particularly in the vicinity of Miners Lake and Long Bay) are extensive chaotic deposits (probably formed through mass slumping) and one of the thickest sequences of conglomerate known in the Orca Groupmore than $300 \mathrm{~m}$ of matrix-supported conglomerate that has subordinate intervals of massive sandstone and thinly interbedded sandstone and mudstone. These facies associations indicate inner-fan deposition (Nelson and others, 1985).

Also, metamorphic grade does not change along the Contact fault in western Prince William Sound. Along the northern part of the Sargent Icefield and

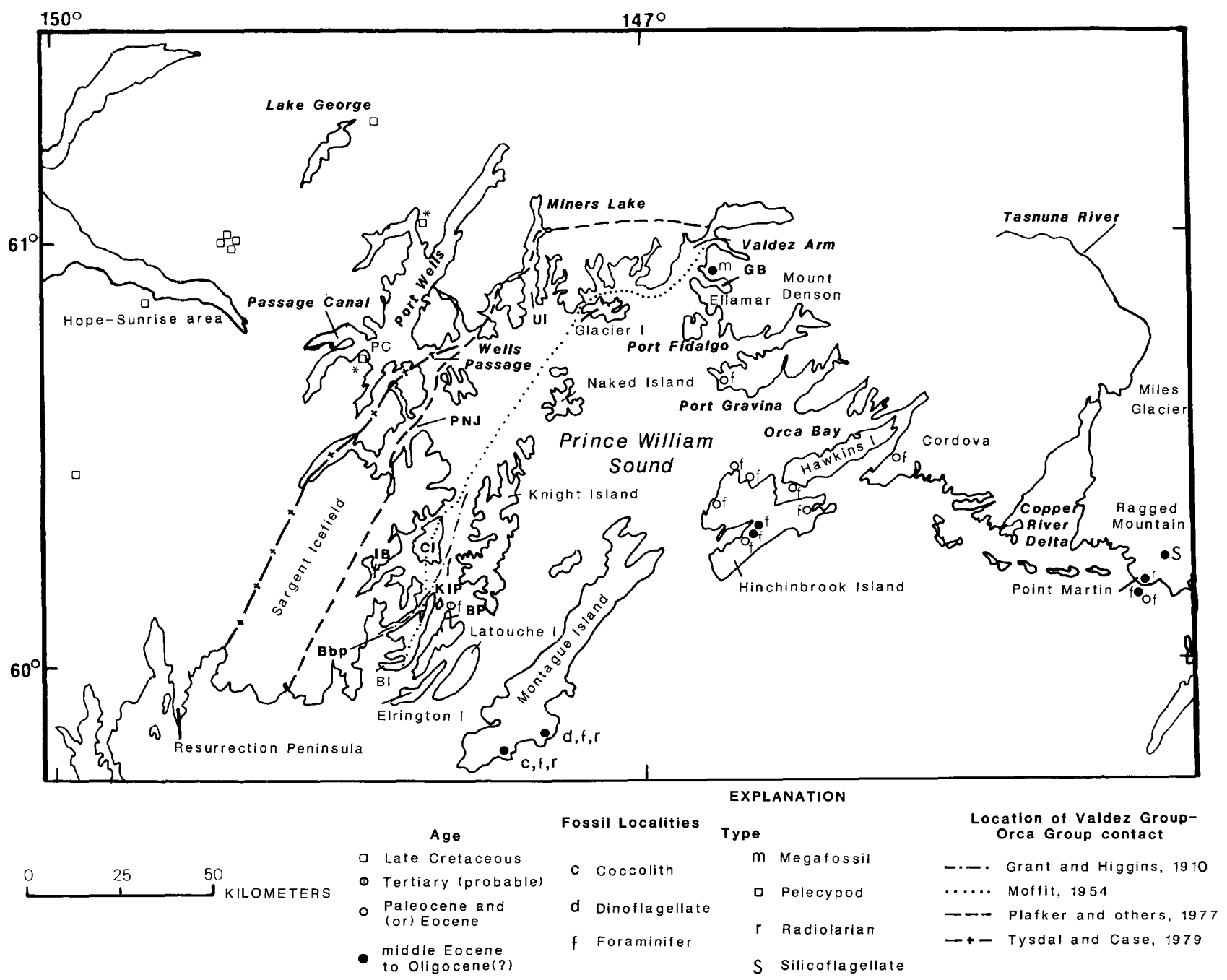

Figure 4. Fossil localities and location of Valdez Group-Orca Group contact in western Prince William Sound as delineated by previous workers. Fossil localities marked * were collected in float. Bbp, Bainbridge Passage; BI, Bainbridge Island; BP, Bear Point; CI, Chenega Island; GB, Galena Bay; IB, Icy Bay; KIP, Knight Island Passage; PC, Point Cochrane; PNJ, Port Nellie Juan; UI, Unakwik Inlet. See figure 1 for location. 
between Port Nellie Juan and Passage Canal, rocks of the prehnite-pumpellyite facies are present on both sides of the fault. Farther south, rocks of lower- and mid-greenschist facies crop out both east and west of the fault (Goldfarb and others, 1986; M.L. Miller, written commun., 1985).

Thus, there is no paleontologic lithologic, metamorphic, or structural criterion that allows easy placement of the Orca-Valdez contact in western Prince William Sound. Reconnaissance studies of the sandstone of both groups, however, indicated that sandstone composition might aid in the determination of the location of the Orca-Valdez boundary.

\section{PREVIOUS PETROGRAPHIC STUDIES}

The petrography of the sandstone of the Valdez Group in Prince William Sound has previously been studied only in a limited area around the Hope-Sunrise mining district (Mitchell, 1979). Petrographic data for correlative rocks to the west of Prince William Sound have been published for the Shumagin Formation (Burk, 1965; Moore, 1973) and the Kodiak Formation (Connelly, 1978; Winkler, in Nilsen and Moore, 1979). Petrography of the (at least in part) correlative Sitka Graywacke to the east of Prince William Sound was studied by Decker (1980). The study by Zuffa and others (1980) is an overview of the rock-fragment petrography for sandstone throughout the Chugach terrane.

The major petrographic study of the Orca Group was the investigation of the Hinchinbrook Island area by Winkler (1976). McGlasson (1976) provided a few point counts for sandstone of the Orca Group on Knight Island. The petrography of correlative rocks to the west (the Sitkalidak and Ghost Rocks Formations) was discussed by Moore and others (1983) and Winkler (in Nilsen and Moore, 1979).

These previous studies indicated that the sandstones of the Orca and Valdez Groups may be petrographically distinguishable. The mean

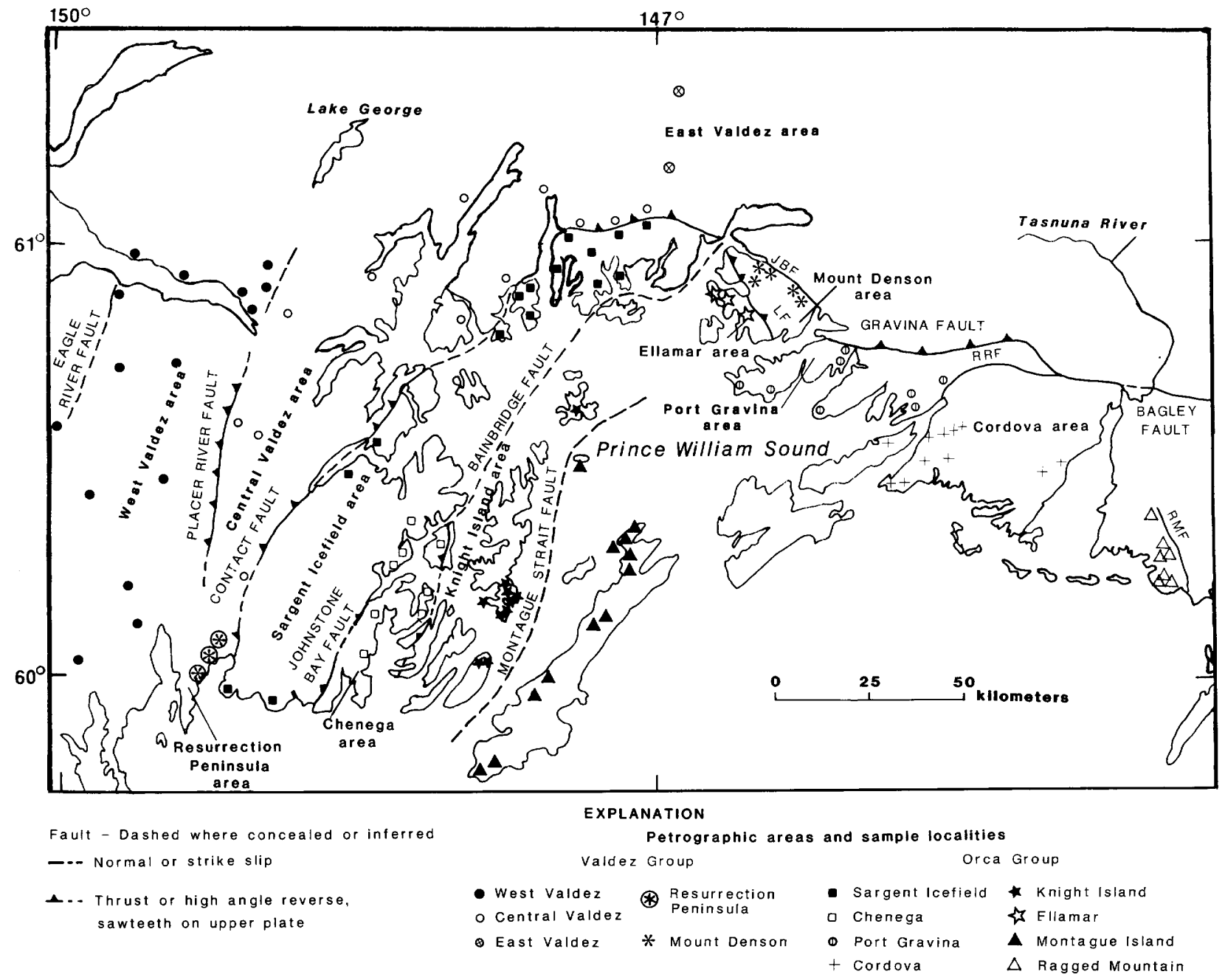

Figure 5. Location of petrographic areas and samples point-counted for this study. JBF, Jack Bay fault; LF, Landlock fault; RMF, Ragged Mountain fault; RRF, Rude River fault. See figure 1 for location. 
composition of the Valdez samples studied by Mitchell (1979) is $Q$ (total monocrystalline and polycrystalline quartz) $=20, F$ (total feldspar) $=24$, and $L$ (total lithic clasts) $=56$, whereas that of the Orca samples studied by Winkler (1976) is $\mathrm{Q}=43, \mathrm{~F}=46$, and $\mathrm{L}=11$.

This study seeks to test whether this striking compositional difference characterizes the Orca and Valdez Group sandstones throughout the Prince William Sound area. That is, is there a sharp change in the composition of the sandstone of the Prince William Sound area, and, if so, does it coincide with the current placement of the contact between the Valdez and Orca Groups? Dumoulin (1984) and Winkler and others (1984) presented the preliminary results of this study.

\section{METHODOLOGY}

The present investigation sought to obtain as wide a distribution of samples as possible in the study area. However, in certain areas, metamorphism and (or) deformation obliterated too much of the original fabric and composition to allow determination of sedimentary modes and provenance. Thus, few samples collected east of longitude $147^{\circ}$ and north of the Contact fault system were suitable for point counts.

Further constraints on sample selection were based on grain size and the percentage of matrix. Because the compositional mode of different size fractions may differ significantly (Odum, 1975; Ingersoll and others, 1984), medium-grained samples (samples having an average grain size between 0.25 and $0.5 \mathrm{~mm}$ ) were used to facilitate comparison with the results of previous studies, as well as with the provenance fields delineated by Dickinson and Suczek (1979). Some point counts of coarser and finer grained sandstones were performed on samples from areas where medium-grained rocks were not available; however, these point counts, although mentioned in the discussion, are not included in the final point-count tabulations. Samples composed of more than 25 percent matrix were also excluded; such samples have probably undergone too much alteration to allow determination of original modes (Dickinson and Suczek, 1979; Ingersoll and Suczek, 1984).

A total of 950 samples from the Valdez and Orca Groups were examined for this study; 111 of the leastaltered samples were chosen for point-count analysis. Detrital grains were counted at 200 magnification using a 1-mm-grid spacing; all point-counted thin sections were stained with sodium cobaltinitrate to facilitate identification of potassium feldspar. Classification of counted grains in general followed the conventions of Dickinson (1970). However, the Gazzi-Dickinson method (Ingersoll and others, 1984) of assigning sand-sized crystals and grains in larger fragments to the crystal or grain category, rather than to the larger grain or fragment category, was not used. Although this technique seems to reduce variation of composition with grain size (Ingersoll and others, 1984), it was not used by previous workers (Decker, 1980; Winkler, 1976), with whose results I wished to compare my findings. Most lithic clasts in the rocks of this study are sufficiently fine grained that use of the Gazzi-Dickinson technique does not significantly alter the final modes. Four hundred framework grains (that is, all grains except silt, clay, other matrix, and cement) were counted for each sample.

To facilitate statistical analysis and comparison with previous work, the point counts are grouped according to geographic areas within the Prince William Sound region; these areas are separated by major faults and (or) geographic breaks, such as large bodies of water. Samples from the Valdez Group are subdivided into five categories; those from the Orca Group are separated into eight categories (fig. 5).

R.J. Goldfarb (written commun., 1985) carried out a statistical analysis of the Prince William Sound point-count data. Trend-surface analysis was used to look for spatial trends in 50 samples collected from western Prince William Sound. Planar (first-degree) surfaces were fitted to the data using least-squares methodology. Discriminant-function analysis was performed on the entire data base of this study in order to identify which petrographic variables best discriminate between selected geographic areas. The computer program DISCRIMINANT of the Statistical Package for the Social Sciences System (Nie and others, 1975) was used.

\section{RESULTS OF STUDIES OF VALDEZ GROUP SAMPLES}

\section{West, Central, and East Valdez Areas}

The majority of Valdez Group samples suitable for point-count study came from the western part of Prince William Sound, that is, west of longitude $147^{\circ}$. In this report, the area east of this line (but north of the Contact fault system) is designated the east Valdez area (fig. 5). West of this line, the central Valdez area extends north and west of the Contact fault to the Placer River fault; the area west of the Placer River fault is the west Valdez area. Samples collected from the two subareas in these geographic divisions have anomalous compositions relative to the majority of Valdez Group samples; these subareas will be treated separately. The area south of the unnamed fault that separates predominantly mafic volcanic rocks of the Resurrection Peninsula from predominantly sedimentary rocks to the north (Nelson and others, 1985) is designated the Resurrection Peninsula area. The area between the Jack Bay fault to the north and the Landlock Bay segment of the Contact fault system to the south is the Mount Denson area (fig. 5).

The results of point-count studies of samples from the main part of the Valdez Group appear in table 1 and figure 6 . In generul, samples collected from the west, central, and east Valdez areas are quite similar. All are subquartzose, and most are feldspatholithic or lithofeldspathic (following the usage of Crook, 1960)-that is, they contain less than 75 percent detrital quartz, and the ratio of feldspar to lithic grains is between $1: 3$ and $3: 1$. Samples are very poorly sorted to moderately well sorted (based on visual comparison with the scale in Pettijohn and 
others, 1973); most contain $10-20$ percent matrix. This matrix consists of a complex mixture of or thomatrix and epimatrix, as defined by Dickinson (1970)-that is, recrystallized detrital clays intergrown with phyllosilicate minerals, epidote, and sphene that were introduced primarily during diagenesis. In some samples, pseudomatrix (deformed interstitial sedimentary lithic fragments) is also present. Onethird of the point-counted samples contain trace amounts (less than 1 percent) of calcite and (or) zeolite cement; one sample contains 8 percent patchy calcite cement.

West, central, and east Valdez-area samples contain relatively low percentages of detrital quartzose grains-between 6 and 30 percent of the total framework grains (fig. $7 \mathrm{a}$ and b). (Unless otherwise noted, all clast percentages in the following discussion are percentages of framework grains.) Most of this quartz is monocrystalline, and the grains show both straight and undulatory extinction. Some of the quartz grains have features attributable to a volcanic provenance (bipyramidal form and resorbed margins), but more common are rounded to angular grains that exhibit slightly undulatory extinction--such grains may be derived from plutonic or metamorphic source rocks (Folk, 1974). Chert-to-total-quartz ratios (C/Q) in these samples are low, in most instances less than 0.1. Some of the rare chert grains noted contain recrystallized radiolarians.

Feldspar contents are moderate and range from 23 to 45 percent. Plagioclase-to-total-feldspar ratios $(\mathrm{P} / \mathrm{F})$ are high $(0.68-0.99)$; many of the plagioclase grains are twinned, and some are zoned. Calcite and sericite alteration is extensive in a minority of the plagioclase grains. Twelve samples contain no potassium feldspar. A few samples contain 9-12 percent potassium feldspar, but most contain 2-5 percent. Trace amounts of microcline are present in a few samples.

Lithic-clast content of the Valdez Group samples is moderate to high (28-66 percent). Volcanic-lithicto-total-lithic-clast ratio $(\mathrm{V} / \mathrm{L})$ is varied but fairly high; it ranges from 0.1 to 0.93 , but is 0.5 or greater in most samples. Most of the volcanic lithic clasts have felsitic or lathwork textures; only a few microlitic grains were observed. Felsitic grains constitute as much as 16 percent of the total framework-grain content; lathwork grains reach a high of 31 percent in a sample from the west Valdez area. Subordinate but notable amounts of metamorphic (as much as 22 percent) and sedimentary (as much as 16 percent) lithic clasts occur in the Valdez Group samples studied. Mudstone and silty mudstone are the main types of sedimentary lithic clasts; fine-grained metasedimentary rocks (phyllite and slate) dominate the metamorphic-clast suite.

Heavy minerals are locally abundant. Pyroxene and amphibole are present in about half the Valdez Group samples and constitute more than 4 percent of a few samples. Other heavy minerals observed include garnet, allanite, sphene, zircon, and tourmaline. Micas (mostly biotite, minor muscovite, and chlorite) constitute less than 3 percent in most samples, but reach 10 percent in a few.

Table 1.--Composition of sandstone of the Valdez Group from the west Valdez ( $n=15)$, east Valdez ( $n=2$ ), and central Valdez $(n=12)$ areas

[Hope-Sunrise district data ( $n=19)$ from Mitchell (1979). The first twelve categories represent percentage of total framework grains, except for matrix, which represents percentage of the whole rock. Quartzose grains (total), feldspar (total) and lithic fragments (total) equal 100 percent. All means and standard deviations represent percent, except for the last three categories, which are ratios. See figure 6 for graphic presentation of data, n.d., no data]

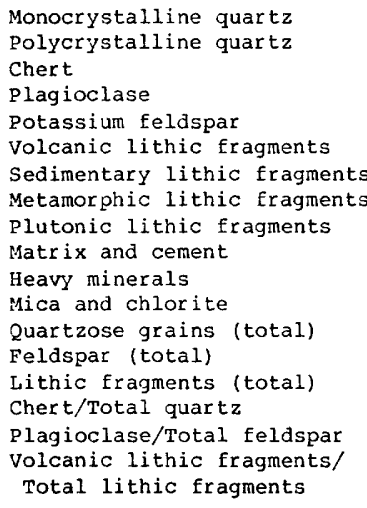

\begin{tabular}{|c|c|c|c|c|c|c|}
\hline \multicolumn{2}{|c|}{$\begin{array}{c}\text { West Valdez } \\
\text { area }\end{array}$} & \multicolumn{2}{|c|}{$\begin{array}{c}\text { East Valdez } \\
\text { area }\end{array}$} & \multicolumn{2}{|c|}{$\begin{array}{c}\text { Central Valdez } \\
\text { area }\end{array}$} & \multirow{2}{*}{$\begin{array}{c}\begin{array}{c}\text { West Valdez } \\
\text { area (Hope- } \\
\text { Sunrise } \\
\text { district) }\end{array} \\
\text { Mean }\end{array}$} \\
\hline Mean & $\begin{array}{l}\text { Standard } \\
\text { deviation }\end{array}$ & Mean & $\begin{array}{l}\text { Standard } \\
\text { deviation }\end{array}$ & Mean & $\begin{array}{l}\text { Standard } \\
\text { deviation }\end{array}$ & \\
\hline 10.8 & 4.1 & 8.5 & 3.2 & 19.3 & 3.4 & 13.4 \\
\hline 2.4 & 1.5 & 2.3 & 1.8 & 4.3 & 1.9 & 2.0 \\
\hline 1.5 & 2.0 & 2.8 & 2.8 & 0.9 & 0.8 & 0.7 \\
\hline 29.3 & 8.0 & 40.1 & 5.5 & 29.4 & 4.8 & 19.5 \\
\hline 1.9 & 2.4 & 0 & 0 & 3.9 & 3.8 & 1.8 \\
\hline 32.1 & 13.6 & 26.9 & 0.53 & 11.2 & 5.7 & 31.2 \\
\hline 8.3 & 4.2 & 6.4 & 6.2 & 8.5 & 3.1 & 12.8 \\
\hline 4.7 & 3.6 & 4.3 & 4.2 & 10.8 & 5.1 & 10.8 \\
\hline 1.5 & 1.1 & 0.9 & 0.5 & 1.7 & 1.5 & n.d. \\
\hline 14.8 & 4.6 & 17.8 & 7.4 & 17.3 & 4.9 & 12 \\
\hline 1.9 & 1.5 & 1.8 & 2.5 & 1.8 & 1.1 & n.d. \\
\hline 4.2 & 2.1 & 5.3 & 1.4 & 6.4 & 2.2 & 1.3 \\
\hline 15.6 & 6.7 & 14.5 & 7.8 & 26.5 & 3.5 & 20 \\
\hline 34.9 & 8.5 & 44.5 & 7.8 & 38.5 & 4.5 & 24 \\
\hline 49.5 & 9.9 & 41.0 & 0 & 35.0 & 3.7 & 56 \\
\hline 0.08 & 0.08 & 0.17 & 0.11 & 0.03 & 0.03 & 0.34 \\
\hline 0.89 & 0.08 & 0.98 & 0.1 & 0.83 & 0.12 & 0.82 \\
\hline 0.67 & 0.18 & 0.7 & 0.05 & 0.35 & 0.17 & 0.58 \\
\hline
\end{tabular}


Differences between West Valdez- and Central ValdezArea Samples

Notable differences exist in $\mathrm{Q}-\mathrm{F}-\mathrm{L}$ modes and lithic-clast composition between the west Valdez- and the central Valdez-area samples; the two east Valdez- area samples fit well with the west Valdez samples and are grouped with them in the following discussion. Trend-surface analysis shows an increase in quartz, potassium feldspar, and plagioclase and a decrease in lathwork-textured volcanic clasts in samples from the central Valdez area compared to those from the west
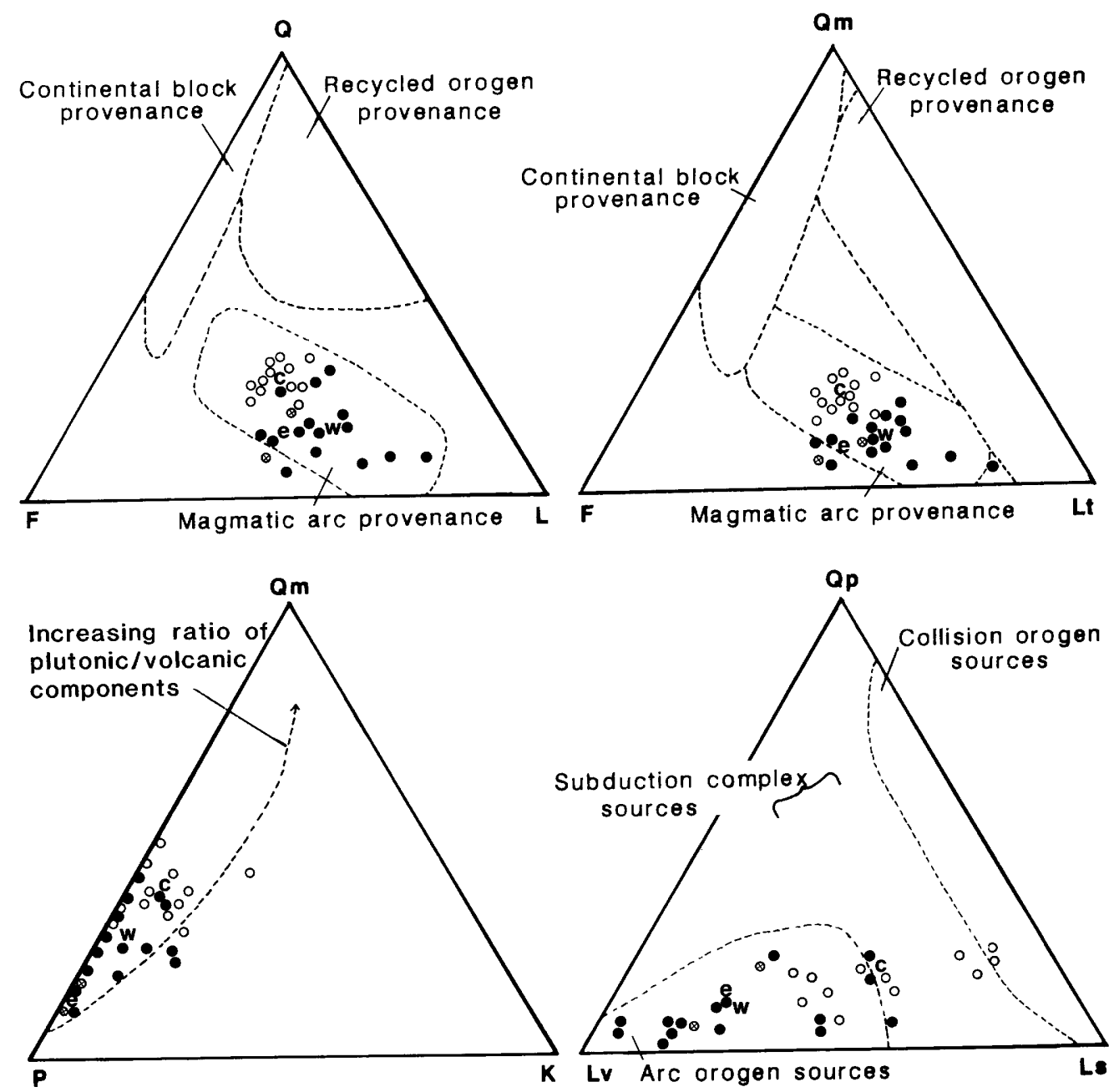

EXPLANATION

AREA

MEAN

CLAST TYPE

$\begin{array}{lll}\bigotimes & \text { West Valdez } & \text { w } \\ \bigotimes & \text { East Valdez } & \text { e } \\ \bigcirc & \text { Central Valdez } & \text { c }\end{array}$

Q Total quartzose grains Qm Monocrystalline quartz

Qp Polycrystalline quartz

L Total lithic grains

Lt Total lithic grains and polycrystalline quartz

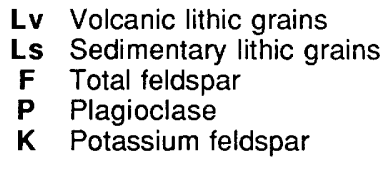

---- Provenance fields ${ }^{+}$

+ Dickinson and Suczek, 1979

Figure 6. Modal analyses of sandstone of the Valdez Group from the west Valdez, east Valdez, and central Valdez areas. 
Valdez area. This trend is significant at the 99percent confidence level (95-percent confidence level for plagioclase) and will be discussed at length below. Discriminant analysis shows that quartz, silty mudstone, and metasedimentary lithic clasts are significantly more abundant in central Valdez-area samples. Furthermore, lathwork grains are more abundant than felsitic grains in most west Valdez-area
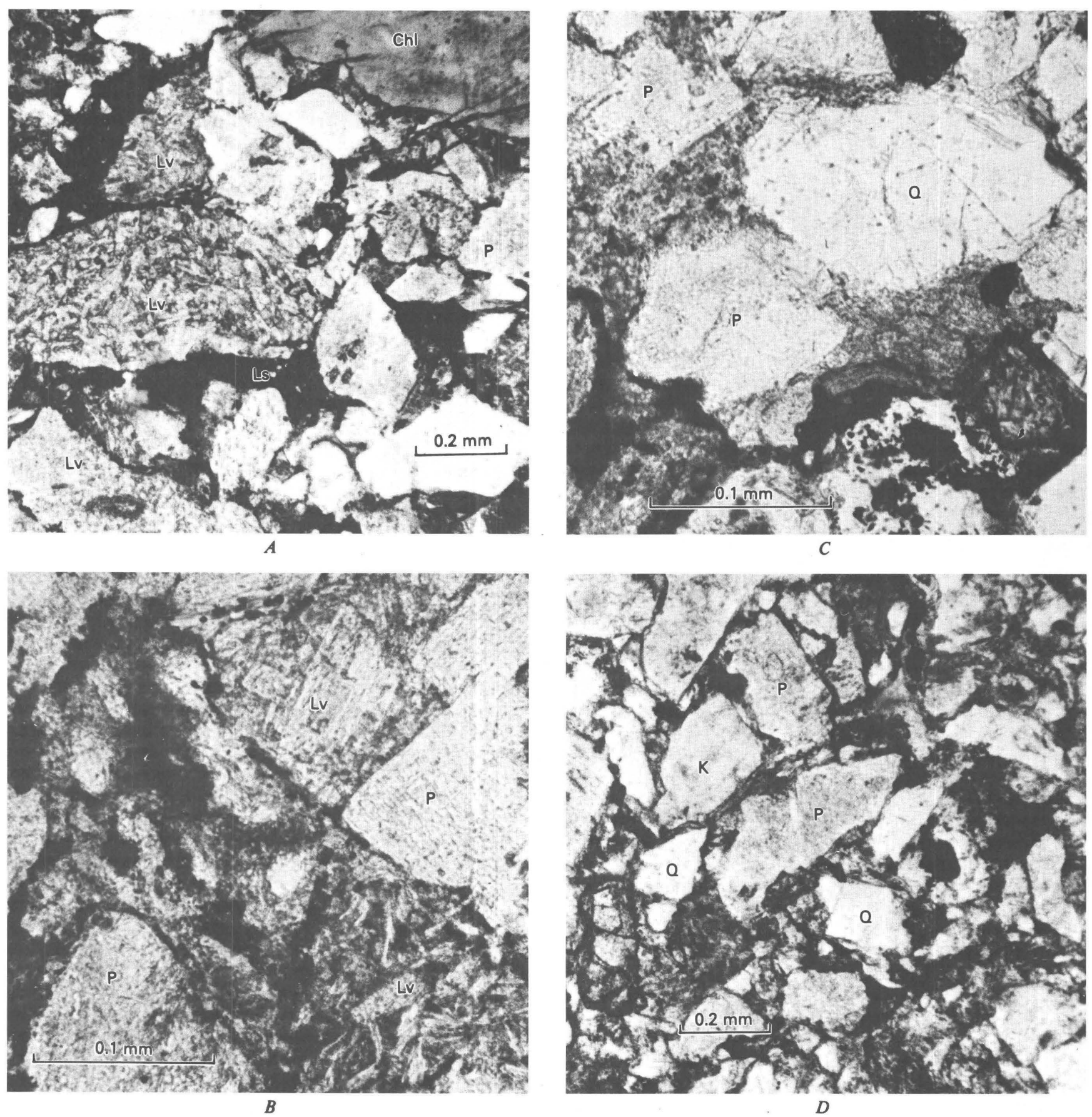

Figure 7. Photomicrographs in transmitted light of thin sections of sandstones from the Valdez Group. Chl, chlorite; K, potassium feldspar; Ls, sedimentary lithic clast; Lv, volcanic lithic clast; P, plagioclase; Q, quartz. A and B, Sandstone samples from the west Valdez area contain abundant lithic volcanic clasts and lesser plagioclase, sedimentary lithic clasts, and chlorite. Sandstone samples from the Resurrection Peninsula, $\underline{\mathrm{C}}$, and the Mount Denson area, $\underline{\mathrm{D}}$, contain few lithic clasts but abundant quartz and feldspar. 
samples, but felsitic grains dominate or are subequal to lathwork grains in most central Valdez-area samples.

\section{Provenance}

Ternary plots of framework-grain modes and detailed analyses of the lithic-clast suite suggest an arc-orogen provenance for Valdez Group sandstone in the Prince William Sound area. This conclusion agrees with that arrived at by previous studies of the Valdez Group (Mitchell, 1979) and correlative rocks (Moore, 1973; Winkler, in Nilsen and Moore, 1979; Decker, 1980; Zuffa and others, 1980) (fig. 8).

Dominance of volcanic clasts over other lithic types, local abundance of pyriboles, and low percentages of quartzose grains all point to an important volcanic source for Valdez Group sedimentary rocks. Based on the compositional interpretations of volcanic lithic textures proposed by Dickinson (1970) and others, the dominance of felsitic and lathwork grains in these samples indicates a bimodal volcanic suite of rhyolitic/dacitic and basaltic composition. In general, this agrees with the findings of Decker (1980) and Mitchell (1979), although they found felsitic grains to be more abundant than lathwork grains, whereas the samples in the present study contained mostly subequal or lathwork-dominant populations. Moore (1973) and Zuffa and others (1980) interpreted the volcanic detritus in Chugach terrane strata as primarily andesitic. Winkler (p. 24, in Nilsen and Moore, 1979) described the volcanic clasts of the correlative Kodiak Formation as "apparently $* * *$ andesitic or basaltic" in composition; textures are dominantly lathwork (G.R. Winkler, U.S. Geological Survey, written commun., 1985).

Some of this apparent disagreement in interpretation may be a result of differences in nomenclature. Moore (1973) reported that volcanic clasts observed in his study were dominantly pilotaxitic-a texture that would have been included in the lathwork category of this study. Zuffa and others (1980) did not use a lathwork category, and they interpreted felsitic textures as indicative of an acidto-intermediate composition. It is also likely that the composition of the volcanic detritus contributed to the Chugach terrane varied through time and across the geographic extent of the depositional area.

Evidence of varied proportions of mafic and felsic volcanic-lithic fragments in west Valdez-area sandstone is provided by chemical analyses of four point-counted samples (table 2, samples 1-4). All four samples contain more than 18 percent volcanic lithic grains. Two samples, in which clasts with lathwork textures predominate over those with felsitic textures, have low concentrations of $\mathrm{SiO}_{2}$ (59 and 61 percent) and relatively high concentrations of $\mathrm{TiO}_{2}$ ( 0.87 and 0.86 percent), $\mathrm{Fe}_{2} \mathrm{O}_{3}$ and $\mathrm{MgO}$. Two samples, in which felsitic textures predominate over lathwork textures, contain considerably more $\mathrm{Si}_{2}$ (72 and 71 percent) and less $\mathrm{TiO}_{2}, \mathrm{Fe}_{2} \mathrm{O}_{3}$, and $\mathrm{MgO}$.

A subordinate plutonic source for Valdez Group sandstone is indicated by the presence of sericitized feldspar, microcline, mica, and plutonic-rock fragments. Another subordinate, but notable, component of the Valdez Group and its correlative rock units is sedimentary lithic grains. Moore (1973), Winkler (in Nilsen and Moore, 1979) and Decker (1980) interpreted these fragments as of intrabasinal origin, although Decker also identified detritus in the Sitka

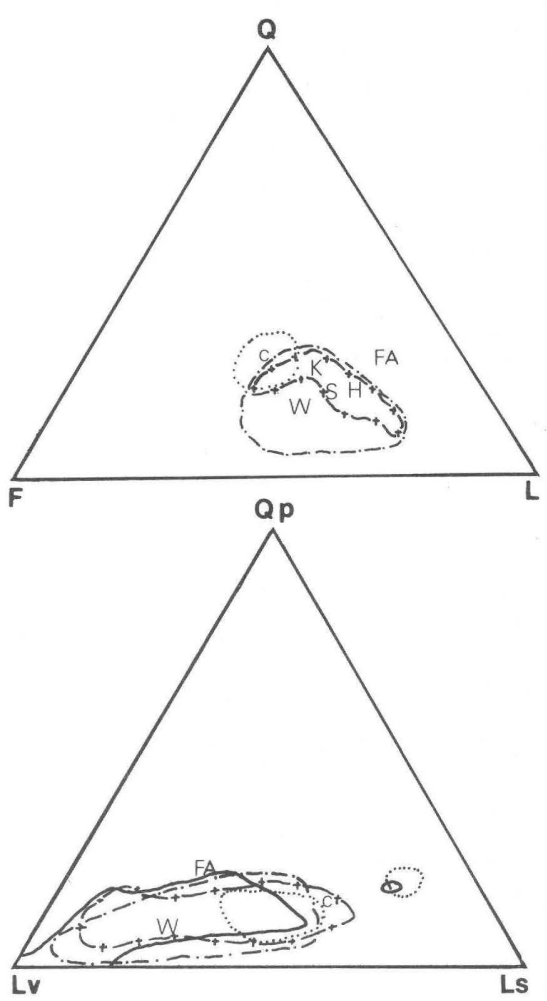

EXPLANATION

UNIT

FIELD

MEAN

Valdez Group

West and east

w

Valdez areas

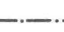

Central Valdez area

Hope-Sunrise area

H

Shumagin Formation

S

Kodiak Formation

K

Sitka Graywacke

Ford Arm unit

FA

Chugach terrane flysch facies

Figure 8. Modal analyses of sandstone from the Valdez Group and (at least partly) correlative lithostratigraphic units. Q, total quartzose grains; F, total feldspar; L, total lithic grains; Qp, polycrystalline quartz; Lv, volcanic lithic grains; Ls, sedimentary lithic grains. 
Graywacke as having been recycled from the Cretaceous Kelp Bay Group melange facies. Zuffa and others (1980), however, emphasize that grains from a broad spectrum of sedimentary rock types are present. Samples from the Prince William Sound area also show such a spectrum, ranging from mudstone clasts apparently deformed while still unlithified to angular clasts of sandstone and metasedimentary fragments, such as quartz-muscovite schist and phyllite. The majority of these clasts are of medium grain size, unlike the large "intraclasts" described by Decker (1980). This variety of clast types implies an extrabasinal origin for some of the grains-for example, a previously accreted subduction complex.

Trend-surface analyses and ternary plots of Valdez Group samples from the Prince William Sound area support the interpretation of Zuffa and others (1980) that the primary source for sedimentary rocks of the Chugach terrane was an evolved arc with an increasing degree of dissection to the east. On the provenance diagrams of Dickinson and Suczek (1979), samples from both the west and central Valdez areas plot within the arc-orogen field, but central Valdezarea samples plot nearer the plutonic end of that field (fig. 6). The diagram that shows the ratio of polycrystalline quartzose grains (Qp) to total volcanic lithic grains (Lv) to total sedimentary lithic grains (Ls) shows that the central Valdez-area rocks contain a higher percentage of $\mathrm{Ls}$ in most samples than do the west Valdez-area rocks; furthermore, a distinct subpopulation of central Valdez-area rocks contains Ls clasts as the dominant lithic constituent.

\section{Anomalous Valdez Group Samples}

Samples from the Resurrection Peninsula in western Prince William Sound and the Mount Denson area in eastern Prince William Sound have anomalous compositions when compared to other Valdez Group samples (table 3; figs. 9 and 10). These rocks are dominantly feldspathic and have 12-21 percent matrix of the type previously described for typical Valdez
Group sandstone. A few samples contain trace amounts of calcite cement. Quartz content is low (2434 percent) as in other Valdez Group samples, but feldspar content is high (42-67 percent) and lithic content is low (7-18 percent) (figs. 7c and d).

Mount Denson-area samples have moderate to high $\mathrm{V} / \mathrm{L}$ ratios (0.4-0.65); felsitic textures are dominant in the volcanic clasts. Clasts of mudstone and schist are also abundant. Potassium feldspar content ranges from 7 to 17 percent.

Resurrection Peninsula samples also contain notable amounts of potassium feldspar (8-10 percent), but sedimentary and metamorphic lithic clasts are more abundant than volcanic lithic clasts.

On framework mode diagrams that show ratios of $\mathrm{Q}-\mathrm{F}-\mathrm{L}$ and of monocrystalline quartzose grains (Qm) to feldspar (F) to total lithic and polycrystalline quartzose grains (Lt), the samples from Mount Denson and the Resurrection Peninsula plot in the area between the magmatic arc and continental block fields defined by Dickinson and Suczek (1979), and show no overlap with the west, central, and east Valdez-area samples. On Qp-Lv-Ls diagrams, a predominantly arcorogen provenance is suggested for the Mount Denson samples; Resurrection Peninsula samples show a wide scatter but are closest to the subduction-complex provenance.

The mafic complex of the Resurrection Peninsula was originally thought to intrude Valdez Group flysch (Tysdal and others, 1977), but Nelson and others (1985) mapped the contact as a thrust fault. If the latter interpretation is correct, the Resurrection Peninsula samples in this study (which represent minor amounts of sediment intercalated with the mafic complex south of this thrust fault) may have had a different source than the main body of the Valdez Group. On the other hand, sedimentary rocks of Resurrection Peninsula may have had the same general provenance as other Valdez Group sandstones, but, as suggested by Winkler (1976) for Orca Group sandstones on Hinchinbrook Island, the mafic rocks may have formed temporary barriers that restricted normal sediment influx and allowed deposition of strata having these anomalous

Table 2.--Geochemical analyses of selected sandstone samples of the Valdez and Orca Groups

\begin{tabular}{|c|c|c|c|c|c|c|}
\hline & \multicolumn{4}{|c|}{ Valdez Group } & \multicolumn{2}{|c|}{ Orca Group } \\
\hline & \multicolumn{2}{|c|}{$\begin{array}{l}\text { Lathwork tex- } \\
\text { tures dominant } \\
\text { (west valdez } \\
\text { area) }\end{array}$} & \multicolumn{2}{|c|}{$\begin{array}{c}\text { Felsitic tex- } \\
\text { tures dominant } \\
\text { (west valdez } \\
\text { area) }\end{array}$} & $\begin{array}{l}\text { Quartz- } \\
\text { rich } \\
\text { (Ellamar } \\
\text { area) }\end{array}$ & $\begin{array}{c}\text { Volcani- } \\
\text { clastic (Ragged } \\
\text { Mountain } \\
\text { area) }\end{array}$ \\
\hline & \multicolumn{6}{|c|}{ Locality Sample Number } \\
\hline & 1 & 2 & 3 & 4 & 5 & 6 \\
\hline $\begin{array}{l}\mathrm{SiO}_{2} \\
\mathrm{Al}_{2} \mathrm{O}_{3}\end{array}$ & $\begin{array}{l}60.7 \\
15.8\end{array}$ & $\begin{array}{l}58.6 \\
15.4\end{array}$ & $\begin{array}{l}72.3 \\
12.6\end{array}$ & $\begin{array}{l}70.9 \\
12.8\end{array}$ & $\begin{array}{r}85.9 \\
6.9\end{array}$ & $\begin{array}{l}47.4 \\
13.6\end{array}$ \\
\hline $\mathrm{Fe}_{2} \mathrm{O}_{3}^{3}$ & 7.3 & 7.4 & 4.7 & 4.9 & 1.4 & $\begin{array}{l}13.6 \\
14.2\end{array}$ \\
\hline $\mathrm{MgO}^{3}$ & 3.7 & 5.0 & 1.5 & 1.8 & 0.9 & 5.6 \\
\hline $\mathrm{CaO}$ & 3.2 & 4.0 & 1.0 & 1.0 & 0.5 & 8.8 \\
\hline $\mathrm{Na}_{2} \mathrm{O}$ & 4.0 & 3.5 & 3.1 & 3.6 & 2.6 & 2.5 \\
\hline $\mathrm{K}_{2} \mathrm{O}$ & 1.3 & 2.2 & 1.5 & 1.1 & 0.4 & 0.8 \\
\hline $\mathrm{TiO}_{2}$ & 0.87 & 0.86 & 0.69 & 0.63 & 0.41 & 2.5 \\
\hline $\mathrm{P}_{2} \mathrm{O}_{5}^{2}$ & 0.23 & 0.22 & 0.18 & 0.18 & 0.05 & 0.2 \\
\hline Mno & 0.1 & 0.12 & 0.09 & 0.06 & 0.02 & 0.2 \\
\hline Total & 97.2 & 97.3 & 97.7 & 97.0 & 99.0 & 95.8 \\
\hline
\end{tabular}


compositions. Dickinson (1970) suggested that reworking of volcanic sandstones could concentrate feldspar, and the Resurrection Peninsula samples are, overall, better sorted than other Valdez Group samples. They are also at the lower end of the medium grain-size range. Several workers have suggested that, in some sandstones, decreasing grain size may lead to increasing feldspar content at the expense of lithic grains (Ingersoll and others, 1984). However, the difference between feldspar content in typical and anomalous Valdez Group sandstones, expecially when compared to the slight difference in grain size between these two groups, seems too large to be explained completely by such a process.

Mount Denson-area samples are not particularly fine grained, and they are poorly to very poorly sorted. As presently mapped, the sedimentary rocks in this area have no spatially associated age-correlative volcanic rocks that could have provided barriers to sediment accumulation. Discriminant analysis and ternary plots show a complete overlap between Mount Denson-area sample composition and the composition of those Orca Group samples immediately southeast of the Mount Denson area. The implications of these findings will be discussed at length below.

\section{RESULTS OF STUDIES OF ORCA GROUP SAMPLES}

The samples from the Orca Group also were separated into geographic areas before petrographic and statistical analysis (fig. 5). The area east of the Contact fault and west of the Johnstone Bay fault is here called the Sargent Icefield area. The Chenega area extends east from the Johnstone Bay fault to the
Bainbridge fault of Helwig and Emmet (1981). The Knight Island area includes all the islands west of the Montague Strait fault; the area east of this fault and west of long $147^{\circ} \mathrm{W}$. is the Montague area. The Ragged Mountain area is defined by the Ragged Mountain fault on the east and the change from bedrock to Quaternary cover on the west. All other samples east of longitude $147^{\circ}$ are included in the Port Gravina-Cordova area, with the exception of samples near the Ellamar mining district, which are treated separately.

\section{Eastem Exposures of the Orca Group}

The Port Gravina-Cordova area includes the shoreline of Orca Bay (figs. 4 and 5), the area that Moffit (1954) designated as the type locality of the Orca Group. In the present study, samples collected north of the Rude River fault (Port Gravina area) were analyzed separately from those collected south of the fault (Cordova area). However, the samples from both areas were found to be so similar that they are treated as a single group in the following discussion (table 4, fig. 11). Most of the sumples are feldspathic and contain 10-15 percent matrix. As described earlier for Valdez Group samples, the matrix in these (and all other) Orca Group samples consists primarily of clay that is, at least in part, recrystallized, phyllosilicate minerals, epidote, and sphene; epimatrix, orthomatrix, and the pseudomatrix of Dickinson (1979) cannot easily be distinguished and were not formally separated during point counts. About a third of the samples contain localized cement-mostly calcite and, to lesser degree, zeolite (laumontite). Samples range from moderately well sorted to very poorly sorted.

Table 3.--Composition of sandstone of the Valdez Group from the Mount Denson $(n=5)$ and Resurrection Peninsula $(n=3)$ areas

[See table 1 for further explanation of parameters. See figure 9 for graphic presentation of data]

\begin{tabular}{|c|c|c|c|c|}
\hline & \multicolumn{2}{|c|}{$\begin{array}{l}\text { Mount Denson } \\
\text { area }\end{array}$} & \multicolumn{2}{|c|}{$\begin{array}{l}\text { Resurrection } \\
\text { Peninsula } \\
\text { area }\end{array}$} \\
\hline & Mean & $\begin{array}{l}\text { Standard } \\
\text { deviation }\end{array}$ & Mean & $\begin{array}{l}\text { Standard } \\
\text { deviation }\end{array}$ \\
\hline Monocrystalline quartz & 22.6 & 2.3 & 23.4 & 3.9 \\
\hline Polycrystalline quartz & 2.9 & 1.4 & 3.8 & 2.5 \\
\hline Chert & 0.5 & 0.3 & 0.7 & 0.5 \\
\hline Plagioclase & 46.4 & 7.2 & 42.3 & 9.1 \\
\hline Potassium feldspar & 9.4 & 4.1 & 13.3 & 0.7 \\
\hline Volcanic lithic fragments & 6.2 & 2.8 & 2.5 & 0.7 \\
\hline Sedimentary lithic fragments & 1.8 & 0.8 & 3.3 & 4.1 \\
\hline Metamorphic lithic fragments & 2.8 & 1.3 & 5.9 & 6.1 \\
\hline Plutonic lithic Eragments & 0.8 & 0.6 & 0.7 & 0.7 \\
\hline Matrix and cement & 18.3 & 2.2 & 18.2 & 4.4 \\
\hline Heavy minerals & 2.4 & 0.5 & 3.3 & 2.1 \\
\hline Micas and chlorite & 3.7 & 2.2 & 3.6 & 3.2 \\
\hline Quartzose grains (total) & 27.7 & 2.4 & 30.3 & 8.1 \\
\hline Feldspar (total) & 60.1 & 5.7 & 56.4 & 12.1 \\
\hline Lithic fragments (total) & 12.3 & 4.7 & 13.3 & 6.0 \\
\hline Chert/Total quartz & 0.02 & 0.01 & 0.02 & 0.02 \\
\hline $\begin{array}{l}\text { Plagioclase/Total feldspar } \\
\text { Volcanic lithic fragments/ }\end{array}$ & 0.82 & 0.07 & 0.79 & 0.05 \\
\hline Total lithic fragments & 0.53 & 0.11 & 0.25 & 0.18 \\
\hline
\end{tabular}


Quartz contents are low to moderate (9-32 percent) (fig. 12a). Grains with both straight and undulous extinction are present. Most grains are monocrystalline and of relatively nondescript plutonic or metamorphic type. $\mathrm{C} / \mathrm{Q}$ ratios are low (less than 0.05); most samples contain less than 1 percent chert.
Feldspar content is high (44-63 percent) and is mostly plagioclase. ( $\mathrm{P} / \mathrm{F}$ ratios range from 0.71 to 0.96.) About 20 percent of the plagioclase grains are obviously twinned, and some grains are normally zoned. Potassium feldspar is present in all samples and constitutes 5-10 percent of most. One-third of the
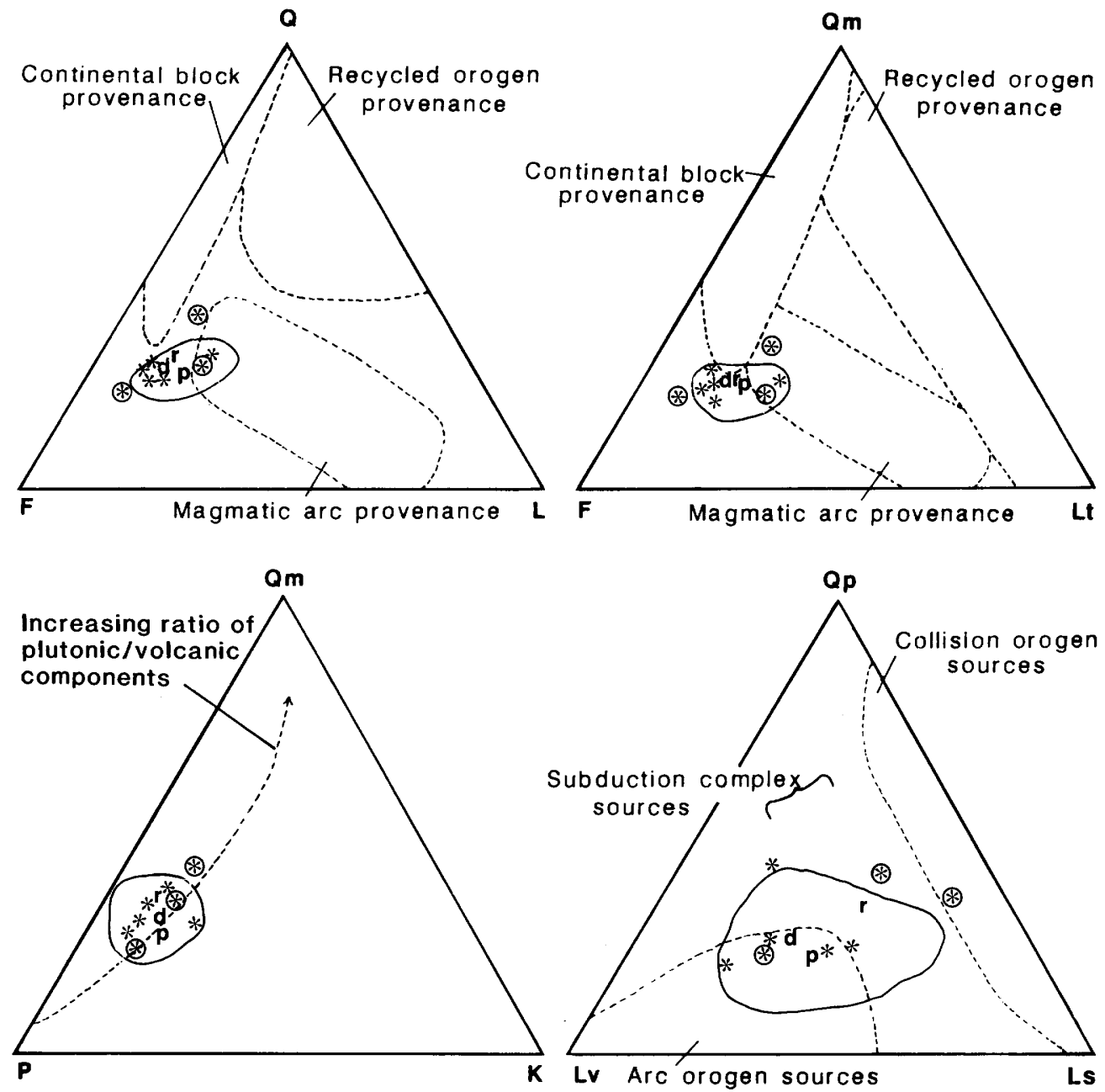

EXPLANATION

AREA

MEAN

CLAST TYPE

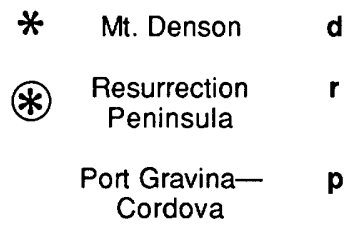

Q Total quartzose grains

Qm Monocrystalline quartz

Qp Polycrystalline quartz

L Total lithic grains

Lt Total lithic grains and polycrystalline quartz

Lv Volcanic lithic grains

Ls Sedimentary lithic grains

F Total feldspar

P Plagioclase

$p$

$\mathbf{K}$

Potassium feldspar

-.---- Provenance fields ${ }^{+}$

\footnotetext{
+ Dickinson and Suczek, 1979
}

Figure 9. Modal analyses of sandstone of the Valdez Group from the Mount Denson and Resurrection Peninsula areas compared with analyses of sandstone of the Orca Group from the Port Gravina-Cordova area. 

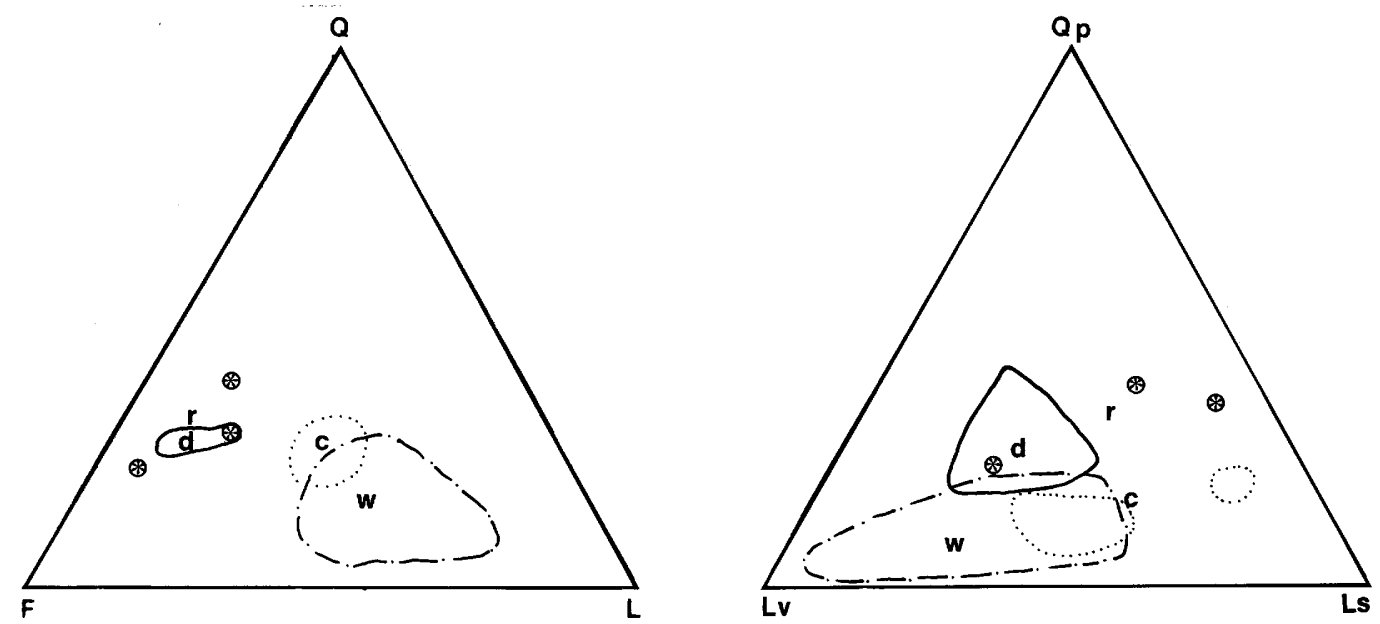

\section{EXPLANATION}

\begin{tabular}{lcc}
\multicolumn{1}{c}{ AREA } & FIELD & MEAN \\
Mt. Denson & & d \\
Resurrection Peninsula & $\circledast$ & r \\
West and east Valdez & - & w \\
Central Valdez & $\ldots \ldots \ldots$ & c
\end{tabular}

Figure 10. Modal analyses of sandstone of the Valdez Group from the Mount Denson and Resurrection Peninsula areas compared with those from the west Valdez, central Valdez, and east Valdez areas. Q, total quartzose grains; F, total feldspar; L, total lithic grains; Qp, polycrystalline quartz; Lv, voleanic lithic grains; Ls, sedimentary lithic grains.

Table 4.--Composition of sandstone of the ọca Group from the Cordova ( $n=11$ ) and Port Gravina $(n=8)$ areas, eastern Prince William Sound

[Hinchinbrook area data $(n=59)$ from Winkler (1976). See table 1 for further explanation of parameters. See figure 11 for graphic presentation of data. n.d., no data]

\begin{tabular}{|c|c|c|c|c|c|c|}
\hline \multirow[b]{3}{*}{ Monocrystalline quartz } & \multicolumn{2}{|c|}{ Cordova area } & \multicolumn{2}{|c|}{$\begin{array}{c}\text { Port Gravina } \\
\text { area }\end{array}$} & \multicolumn{2}{|c|}{$\begin{array}{l}\text { Hinchinbrook } \\
\text { area }\end{array}$} \\
\hline & Mean & $\begin{array}{l}\text { Standard } \\
\text { deviation }\end{array}$ & Mean & $\begin{array}{l}\text { Standard } \\
\text { deviation }\end{array}$ & Mean & $\begin{array}{l}\text { Standard } \\
\text { deviation }\end{array}$ \\
\hline & 22.1 & 2.8 & 21.6 & 3.0 & n.d. & n.d. \\
\hline Polycrystalline quartz & 2.4 & 1.1 & 2.8 & 1.5 & n.d. & n.d. \\
\hline Chert & 0.6 & 0.5 & 0.4 & 0.5 & n.d. & n.d. \\
\hline Plagioclase & 42.5 & 4.0 & 45.0 & 7.9 & n.d. & n.d. \\
\hline $\begin{array}{l}\text { Potassium feldspar } \\
\text { Volcanic lithic fragments }\end{array}$ & $\begin{array}{l}9.1 \\
6.1\end{array}$ & $\begin{array}{l}3.3 \\
2.3\end{array}$ & $\begin{array}{l}9.6 \\
5.7\end{array}$ & $\begin{array}{l}3.2 \\
2.4\end{array}$ & $\begin{array}{l}\text { n.d. } \\
\text { n.d. }\end{array}$ & $\begin{array}{l}\text { n.d. } \\
\text { n.d. }\end{array}$ \\
\hline Sedimentary lithic fragments & 3.6 & 1.9 & 2.7 & 1.2 & n.d. & n.d. \\
\hline Metamorphic lithic fragments & 3.5 & 1.3 & 3.0 & 2.5 & n.d. & n.d. \\
\hline Plutonic lithic fragments & 2.5 & 1.2 & 2.5 & 1.3 & n.d. & n.d. \\
\hline Matrix and cement & 12.1 & 2.1 & 13.5 & 3.8 & n.a. & n.d. \\
\hline Heavy minerals & 2.6 & 1.1 & 1.6 & 0.6 & n.d. & n.d. \\
\hline Micas and chlorite & 4.2 & 1.7 & $4 \cdot 3$ & 1.9 & n.d. & n.d. \\
\hline Quartzose grains (total) & 26.9 & 3.3 & 26.4 & 4.0 & 43.1 & 7.2 \\
\hline Feldspar (total) & 56.4 & 4.7 & 58.8 & 6.6 & 46.0 & 9.5 \\
\hline Lithic fragments (total) & 16.7 & 4.3 & 14.8 & 4.0 & 10.9 & 7.9 \\
\hline Chert/Total quartz & 0.02 & 0.02 & 0.02 & 0.02 & 0.12 & 0.08 \\
\hline $\begin{array}{l}\text { Plagioclase/Total feldspar } \\
\text { Volcanic lithic fragments/ }\end{array}$ & 0.81 & 0.06 & 0.81 & 0.06 & 0.92 & 0.5 \\
\hline Total lithic fragments & 0.38 & 0.08 & 0.38 & 0.18 & 0.53 & 0.27 \\
\hline
\end{tabular}


samples contain minor amounts of microcline.

Lithic content is low (7-25 percent); V/L ratios are varied $(0.17-0.64)$. Volcanic lithic clasts possess mainly felsitic or lathwork textures and constitute as much as 10 percent of some samples. Volcanic clasts are particularly abundant in sandstone from the Sheep
Bay region; conglomeratic intervals here contain numerous pebbles of felsic porphyry and tuff (Nelson and others, 1985).

Sedimentary lithic clasts (especially mudstone and silty mudstone) and metamorphic lithic clasts (mostly schist, phyllite, and slate) are important
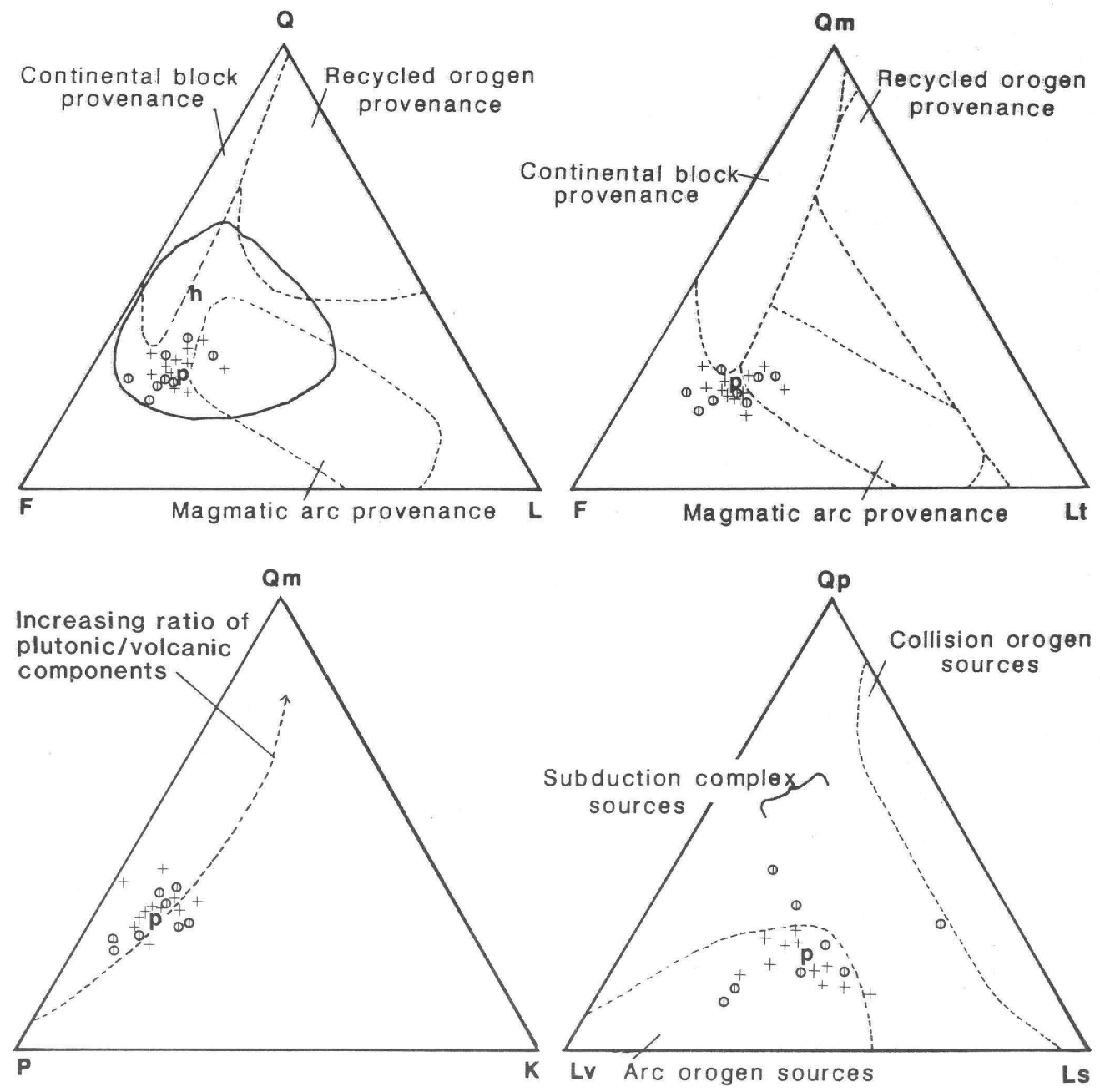

EXPLANATION

AREA

MEAN

CLAST TYPE

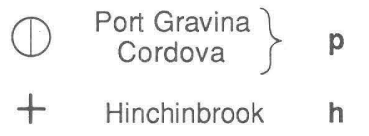

Q Total quartzose grains
Qm Monocrystalline quartz

Qp Polycrystalline quartz

L Total lithic grains

Lt Total lithic grains and polycrystalline quartz

Lv Volcanic lithic grains

Ls Sedimentary lithic grains

F Total feldspar

P Plagioclase

K Potassium feldspar

Provenance fields +

+ Dickinson and Suczek, 1979

Figure 11. Modal analyses of sandstone of the Orca Group from the Port Gravina and Cordova areas compared with analyses of sandstone of the Orca Group from the Hinchinbrook Island area (Winkler, 1976). 


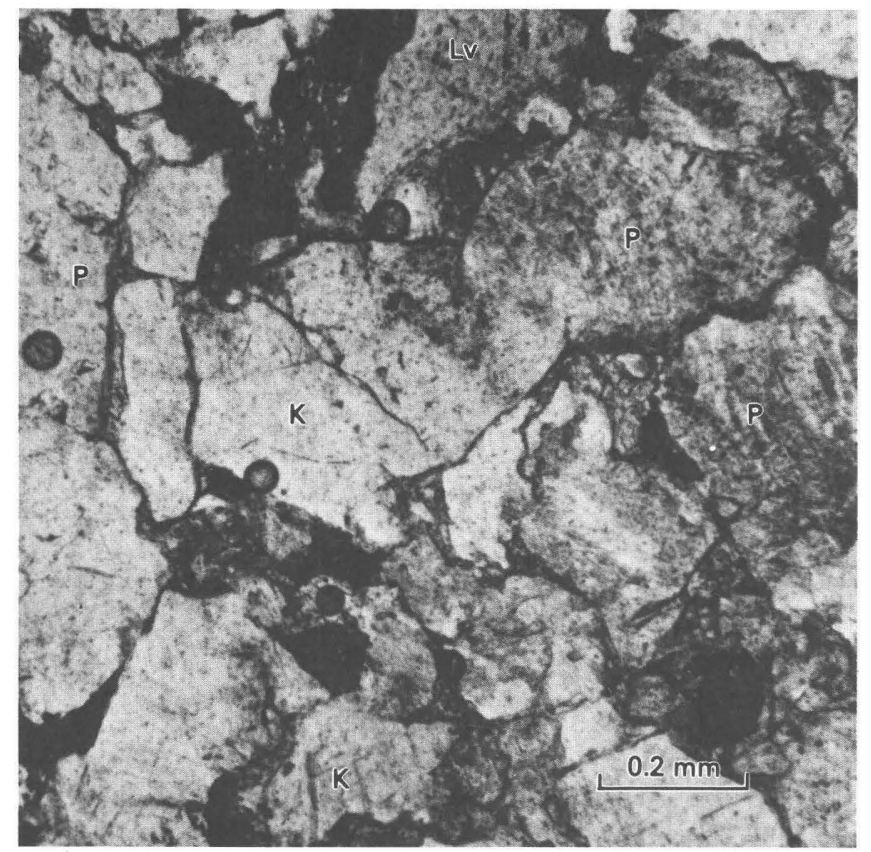

A

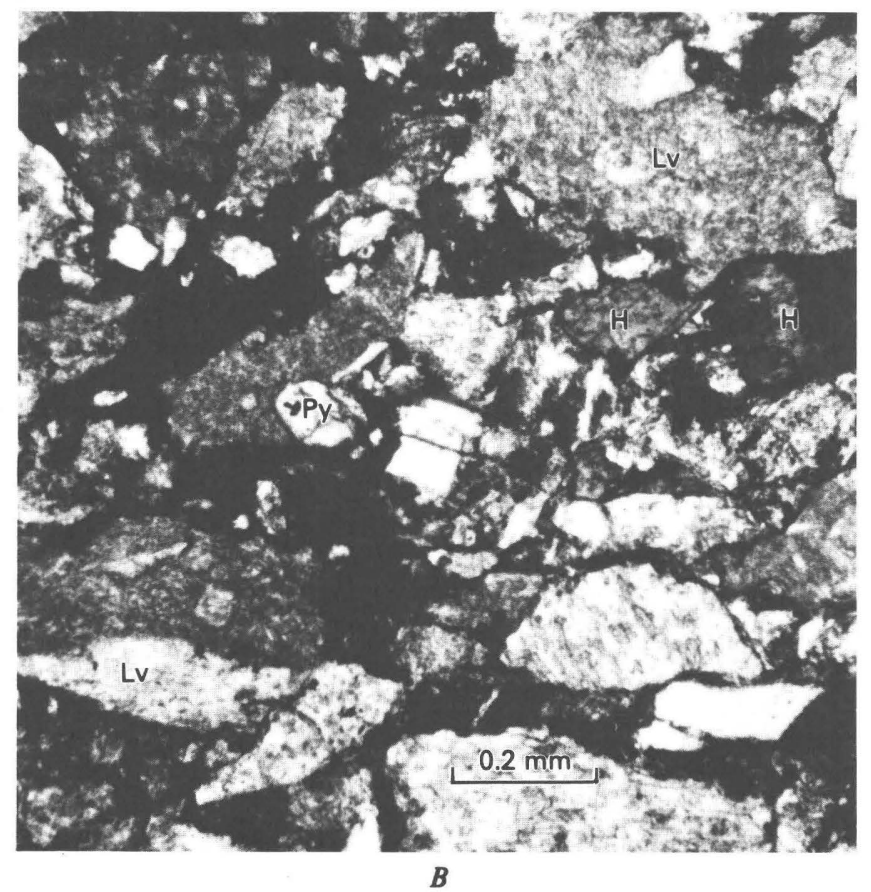

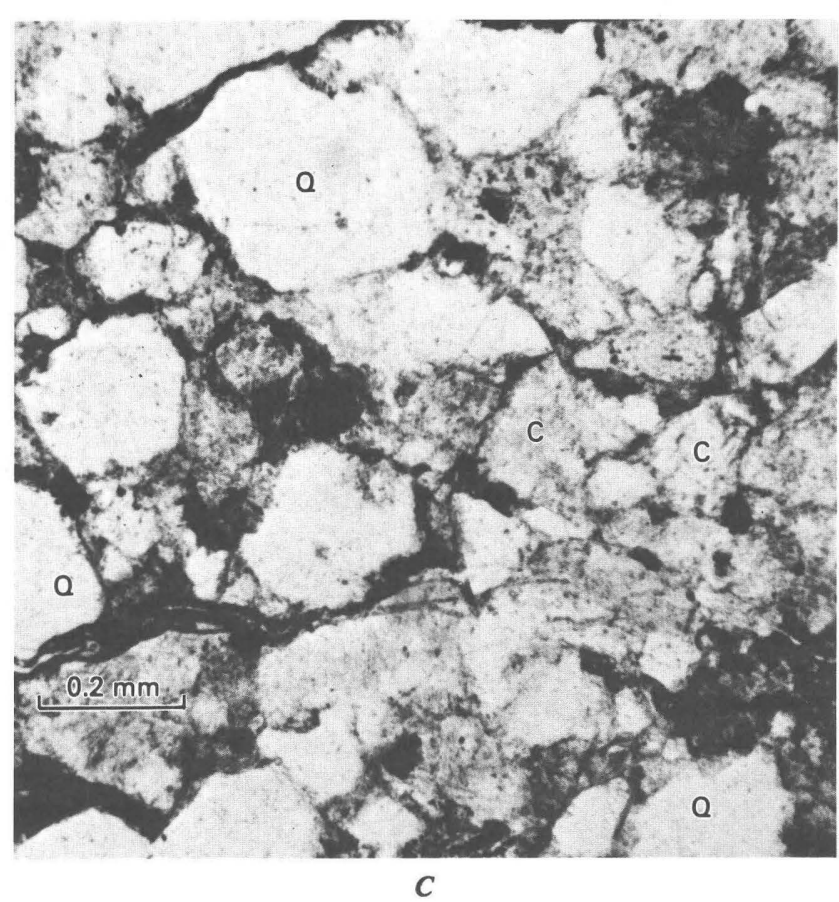

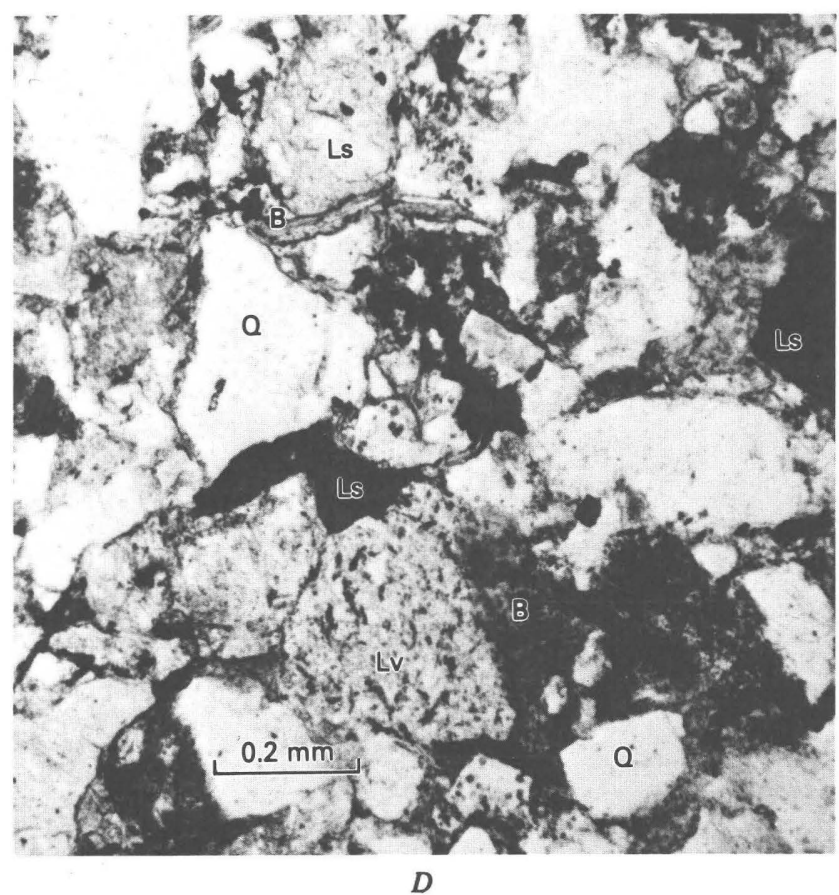

Figure 12. Photomicrographs in transmitted light of thin sections of sandstones from the Orca Group. B, biotite; C, chert; H, hornblende; K, potassium feldspar; Ls, sedimentary lithic clast; Lv, volcanic lithic clast; P, plagioclase; Py, pyroxene; Q, quartz. A, sandstone samples from eastern exposures of the Orca Group (Port Gravina-Cordova area) contain abundant feldspar, and lithic clasts are mostly volcanic. $B$, sandstone samples from western exposures of the Orca Group (Sargent Icefield area) are similar to samples of the Valdez Group from the west and central Valdez areas; they contain abundant heavy minerals indicative of a volcanic provenance. $\mathrm{C}$, sandstone samples from the Ellamar area contain abundant quartz and chert clasts and are better sorted than most Orca Group sandstones. D, sandstone samples from the Montague Island area contain abundant quartz and sedimentary lithic clasts as well as locally abundant biotite. 
subsidiary constituents. Quartz-feldspar symplectite grains and plutonic clasts are a minor but notable component of all samples; coarse-grained sandstone north of Port Fidalgo contains as much as 25 percent plutonic fragments.

Micas constitute 2-4 percent of the composition of most Port Gravina-Cordova samples. Garnet is generally present; other heavy minerals observed include pyroxene, amphibole, pumpellyite, zircon, epidote, allanite, and tourmaline. Several samples slightly too coarse grained to be included in this study contain as much as 3 percent pyriboles.

Comparison of the ternary plots of Port GravinaCordova samples with the provenance fields delineated by Dickinson and Suczek (1979) indicates that the primary source for these Orca Group strata was a deeply dissected volcanic arc. Like the Mount Denson samples, they plot at the junction of the continentalblock and arc-orogen fields on Q-F-L and Qm-F-Lt diagrams. On the $\mathrm{Qp}-\mathrm{LV}-\mathrm{Ls}$ diagram, an are provenance is also indicated, with important contributions from a subduction-complex source.

These results agree with the interpretations suggested by the lithic-clast and heavy-mineral suites described above. The locally abundant pyriboles and volcanic lithic clasts in Port Gravina-Cordova samples may in part reflect an intrabasinal provenanceerosion and reworking of Orca Group volcanic rocks that crop out extensively in parts of the Port GravinaCordova area. However, these volcanic rocks are mafic in composition and could not have provided a source for felsic clasts like those from the Sheep Bay area. Uneroded volcanic cover in less deeply dissected parts of the hypothetical arc source may have provided both felsic and mafic volcanic debris to the Port Gravina-Cordova rocks.

\section{Western Exposures of the Orca Group}

Orca Group samples from western Prince William Sound have important compositional differences fram the eastern-area samples just described (table 5, fig. 13).

The rocks of the Sargent Icefield area (fig. 12b) are moderately well sorted to very poorly sorted; matrix content ranges from 7 to 20 percent, but is 8 to 15 percent in most samples. One-third of the samples contain patchy calcite cement.

The quartz content (16-26 percent) and $C / Q$ ratio (0-0.1) of these rocks are low. Feldspar content is moderate (31-56 percent) and consists mostly of plagioclase ( $\mathrm{P} / \mathrm{F}$ 0.75-0.95). Potassium feldspar content ranges from 1 to 13 percent, but more typically ranges from 7 to 10 percent. Lithic content is low to moderate (18-39 percent) and $\mathrm{V} / \mathrm{L}$ ratios are varied (0.19-0.62). Total volcanic lithic-clast content reaches 11 percent in some samples; felsite grains are somewhat more abundant than lathwork grains in most samples. Sedimentary lithic grains (particularly mudstone and siltstone) and metamorphic lithic grains (phyllite and schist) typically constitute 3-8 percent each. Most samples contain $1-5$ percent micas. Pyroxene and hornblende are locally abundant (7 percent of one sample, but less than 3 percent of most); other heavy minerals noted include garnet, sphene, allanite, epidote, zircon, and tourmaline.

Discriminant analysis indicates that these samples fall between the fields delineated by typical Valdez Group samples (from the west, central, and east Valdez areas) and typical Orca Group samples (from the Port Gravina-Cordova area). Sandstone samples from the Sargent Icefield area contain more potassium feldspar and mica than most Valdez Group

Table 5.--Composition of sandstone of the Orca Group from the Sargent Icefield $(n=15)$ and Chenega $(n=8)$ areas, western Prince William Sound

[Ghost Rocks Formation data $(n=8)$ from Winkler (in Nilsen and Moore, 1979). See table 1 for further explanation of parameters. See figure 13 for graphic presentation of data. n.d., no data]

\begin{tabular}{|c|c|c|c|c|c|}
\hline & \multicolumn{2}{|c|}{$\begin{array}{c}\text { Sargent Icefield } \\
\text { area }\end{array}$} & \multicolumn{2}{|c|}{$\begin{array}{l}\text { Chenega } \\
\text { area }\end{array}$} & \multirow{2}{*}{$\begin{array}{c}\begin{array}{c}\text { Ghost Rocks } \\
\text { Formation }\end{array} \\
\text { Mean }\end{array}$} \\
\hline & Mean & $\begin{array}{l}\text { Standard } \\
\text { deviation }\end{array}$ & Mean & $\begin{array}{l}\text { Standard } \\
\text { deviation }\end{array}$ & \\
\hline Monocrystalline quartz & 17.6 & 3.2 & 20.9 & 3.1 & n.d. \\
\hline Polycrystalline quartz & 3.1 & 1.0 & 3.3 & 1.3 & n.d. \\
\hline Chert & 0.8 & 0.7 & 0.8 & 0.7 & n.d. \\
\hline Plagioclase & 35.8 & 6.0 & 38.2 & 8.7 & n.d. \\
\hline Potassium feldspar & 7.5 & 3.6 & 8.8 & 3.6 & n.d. \\
\hline Volcanic lithic fragments & 11.4 & 4.2 & 11.5 & 4.7 & n.d. \\
\hline Sedimentary lithic fragments & 7.5 & 4.2 & 3.7 & 2.4 & n.d. \\
\hline Metamorphic lithic fragments & 5.7 & 3.5 & 4.5 & 3.7 & n.d. \\
\hline Plutonic lithic fragments & 2.3 & 1.6 & 1.7 & 1.2 & n.d. \\
\hline Matrix and cement & 13.5 & 4.3 & 16.8 & 3.8 & n.d. \\
\hline Heavy minerals & 1.7 & 1.3 & 1.9 & 0.9 & n.d. \\
\hline Micas and chlorite & 5.9 & 2.6 & 3.8 & 1.3 & n.d. \\
\hline Quartzose grains (total) & 23.4 & 4.1 & 26.7 & 4.9 & 21.0 \\
\hline Feldspar (total) & 47.7 & 8.3 & 50.8 & 9.1 & 37.0 \\
\hline $\begin{array}{l}\text { Lithic fragments (total) } \\
\text { Chert/Total quartz }\end{array}$ & $\begin{array}{c}28.9 \\
0.03\end{array}$ & $\begin{array}{l}7.2 \\
0.03\end{array}$ & $\begin{array}{c}22.5 \\
0.03\end{array}$ & $\begin{array}{l}8.6 \\
0.03\end{array}$ & $\begin{array}{l}42.0 \\
0.08\end{array}$ \\
\hline $\begin{array}{l}\text { Plagioclase/Total feldspar } \\
\text { Volcanic lithic grains/ }\end{array}$ & 0.81 & 0.06 & 0.79 & 0.09 & 0.92 \\
\hline Total lithic grains & 0.44 & 0.14 & 0.56 & 0.21 & 0.95 \\
\hline
\end{tabular}


samples, but they contain more felsic, lathwork, and metasedimentary clasts than the Port GravinaCordova samples. On the provenance diagrams of Dickinson and Suczek (1979), Sargent Icefield samples coincide roughly with the fields delineated by central Valdez-area samples; the Sargent Icefield plot extends somewhat farther toward the plutonic end of the are- orogen field on the Q-F-L and Qm-F-Lt diagrams. On the Qp-Lv-Ls diagram, Sargent Icefield samples, like central Valdez-area samples, show some sedimentary input from subduction-complex sources in addition to a primary arc-orogen input.

Chenega-area samples are, in general, quite similar to Port Gravina-Cordova samples and have
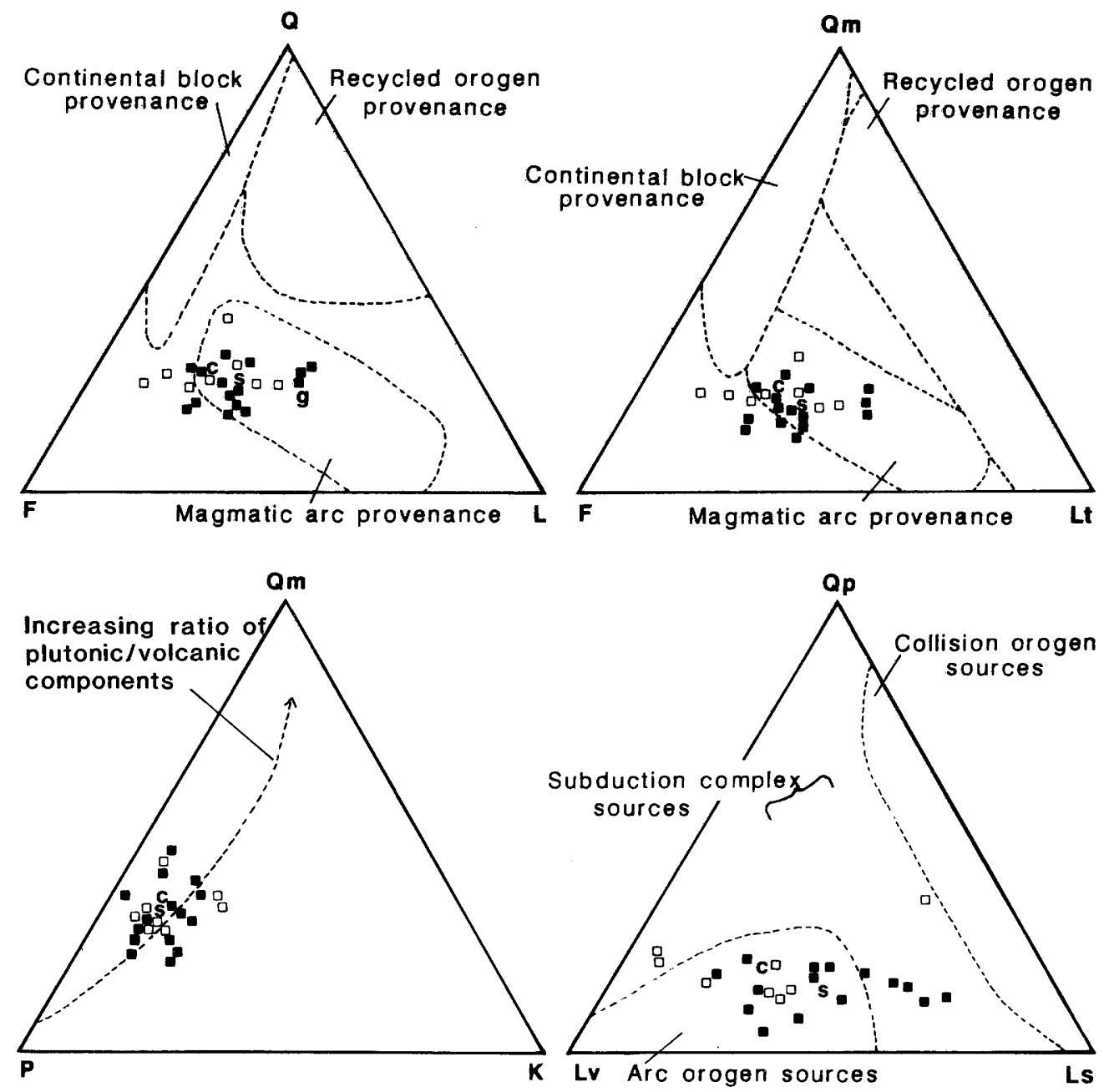

EXPLANATION

AREA

MEAN

CLAST TYPE

\begin{tabular}{|c|}
\hline Sargent Icefield \\
\hline Chenega \\
\hline $\begin{array}{c}\text { Ghost Rocks } \\
\text { Formation }\end{array}$ \\
\hline
\end{tabular}

Q Total quartzose grains

Qm Monocrystalline quartz

Qp Polycrystalline quartz

$L$ Total lithic grains

Lt Total lithic grains and polycrystalline quartz

\author{
Lv Volcanic lithic grains \\ Ls Sedimentary lithic grains \\ F Total feldspar \\ P Plagioclase \\ K Potassium feldspar
}

-.--- Provenance fields ${ }^{+}$

+ Dickinson and Suczek, 1979

Figure 13. Modal analyses of sandstone of the Orca Group from the Sargent Icefield and Chenega areas compared with analyses (from Winkler, in Nilsen and Moore, 1979) of the Ghost Rocks Formation of Moore and others (1983). 
lower lithic and higher feldspar contents than do Sargent Icefield samples. The lithic suite of almost all Chenega sandstones is predominantly volcanic, and felsitic textures are slightly more abundant than lathwork textures.

Trend-surface analysis in western Prince William Sound indicates that the west-to-east compositional changes observed in Valdez Group samples continue across the Contact fault into the Orca Group. Thus, the petrographic analyses of this study (fig. 14) reveal no sharp break in sandstone composition at the Contact fault, which, as presently mapped, juxtaposes the Valdez and Orca Groups. Compositions in both groups become progressively richer eastward in quartz, potassium feldspar, and plagioclase, and poorer eastward in lathwork volcanic clasts (table 6). Trend-
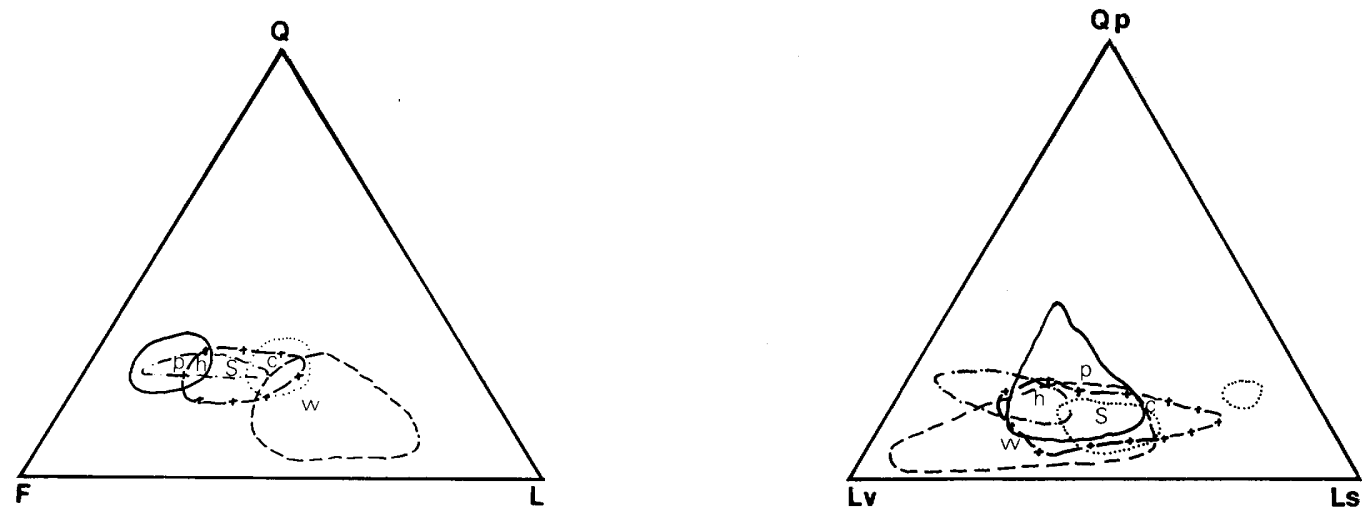

\section{EXPLANATION}

UNIT

FIELD

MEAN

Valdez Group

West and east

Valdez areas

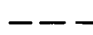

w

Central Valdez area

c

Orca Group

$\begin{array}{lll}\text { Sargent Icefield area } & \text {-+++- } & \text { S } \\ \text { Chenega area } & -\ldots+- & \mathbf{h} \\ \text { Port Gravina- } & \\ \text { Cordova area } & \end{array}$

Figure 14. Comparison of sandstone modal analyses from the Valdez and Orea Groups. $Q$, total quartzose grains; F, total feldspar; L, total lithic grains; Qp, polycrystalline quartz; Lv, volcanic lithic grains; Ls, sedimentary lithic grains.

Table 6.--Statistical summary of first-degree trend surfaces for point-count data

[X-coordinate is longitude, $\mathrm{Y}$-coordinate is latitude, $+=$ significant at the given level, 0 = not significant at the given level]

\begin{tabular}{|c|c|c|c|c|c|c|}
\hline & \multirow[t]{2}{*}{$\begin{array}{l}\text { Percentage of Variance } \\
\text { Accounted for by } \\
\text { Linear Trend }\end{array}$} & \multicolumn{4}{|c|}{$\begin{array}{l}\text { Significance } \\
\text { Level of } \\
\text { Trend }\end{array}$} & \multirow[t]{2}{*}{$\begin{array}{l}\text { Direction of } \\
\text { Trend Increase }\end{array}$} \\
\hline & & \multicolumn{2}{|c|}{0.05} & \multicolumn{2}{|c|}{0.01} & \\
\hline Potassium & & $\mathrm{x}$ & $Y$ & $x$ & $Y$ & \\
\hline feldspar & 36.1 & + & + & + & + & $\mathrm{SE}$ \\
\hline Quartz & 21.6 & + & 0 & + & 0 & $\mathrm{E}$ \\
\hline \multicolumn{7}{|l|}{ Lathwork } \\
\hline volcanic fragments & 31.3 & + & 0 & + & 0 & w \\
\hline Plagioclase & 13.5 & + & + & 0 & 0 & $\mathrm{SE}$ \\
\hline
\end{tabular}


surface analysis indicates that these compositional changes are statistically significant. Although the percentage fit does not exceed about 30 percent of the total variance for any of these components, the trends are significant at the 0.01 level for three of the components (and at the 0.05 level for plagioclase). Thus, these trends could occur by chance less than one time in twenty. Ternary plots and discriminant analysis cannot distinguish sandstone in the central Valdez area from Orca Group sandstones in the Sargent Icefield area. The Q-F-L and Qp-Lv-Ls plots of point-count data indicate a dominantly magmaticarc provenance for both groups, with progressive unroofing from the volcanic cover to the plutonic roots of the arc through time.

\section{Anomalous Orea Group Samples}

Samples from the Knight Island area and the Ellamar area (on trend with, but to the northeast of, Knight Island) have the most quartz-rich compositions of any rocks examined in this study (table 7, fig. 15). Most of the sandstones are moderately well to poorly sorted; a few are very poorly sorted. The Ellamar samples are particularly well sorted compared to most Prince William Sound-area sandstones, and they are at the finer end of the medium-grained size range (fig. 12c).

Knight Island and Ellamar samples are quartz rich (43-72 percent), lithic poor (8-25 percent), and have moderate feldspar contents (17-41 percent). The $\mathrm{C} / \mathrm{Q}$ ratio of these samples is low $(0.04-0.15)$, but total chert contents are higher in these rocks than in any other Prince William Sound-area samples (as much as 11 percent). Geochemical analyses of several pointcounted samples collected from the Knight-Ellamar (combined) area confirm the quartz-rich nature of these rocks; one sample from the Ellamar area contains 86 percent $\mathrm{SiO}_{2}$ (table 2, sample 5). Potassium feldspar is absent in five of the samples, but constitutes as much as 15 percent of the others. The $\mathrm{V} / \mathrm{L}$ ratios are generally low $(0.14-0.59)$. Notable lithic clasts include mudstone, metasedimentary grains, and felsitic and lathwork volcanic grains. Mica (mostly muscovite and biotite) constitutes 5-7 percent of most samples, but reaches 20 percent in a sample collected from Naked Island.

MeGlasson (1976) performed point counts on four sandstone samples from Knight Island and obtained similar results. In general, he found quartz contents to be greater than $\mathbf{4 0}$ percent, lithic clast-content less than 30 percent, and chert, polycrystalline quartz, and detrital phyllosilicate grains quite abundant.

Knight-Ellamar samples do not fit well into any of the provenance fields delineated by Dickinson and Suczek (1979) for Q-F-L and Qm-F-Lt diagrams, but they coincide best with the recycled-orogen provenance. On the Qp-Lv-Ls diagram, these samples fit the subduction-complex source field quite well. Compared to data presented by Valloni and Maynard (1981) for modern deep-sea sands, the best match is with sands from a trailing-edge margin supplied by a collision orogen.

The fields defined by the Knight-Ellamar samples on the $\mathrm{Q}-\mathrm{F}-\mathrm{L}$ and $\mathrm{Qp}-\mathrm{Lv}-\mathrm{Ls}$ diagrams do not overlap the fields defined by the Port Gravina-Cordova-area samples (fig. 16). Sandstones of the Knight Island and Ellamar areas are spatially associated with apparently contemporaneous volcanic rocks so, as postulated for Resurrection Peninsula samples, their anomalous compositions may have resulted (at least in part) from sediment blockage by volcanic barriers. On the other hand, Knight-Ellamar sedimentary rocks may have had

Table 7.--Composition of sandstone of the Orca Group from the Knight Island $(n=10)$ and Ellamar $(n=3)$ areas

[See table 1 for further discussion of parameters. See figure 15 for graphic presentation of data]

\begin{tabular}{|c|c|c|c|c|}
\hline & \multicolumn{2}{|c|}{$\begin{array}{l}\text { Knight Island } \\
\text { area }\end{array}$} & \multicolumn{2}{|c|}{$\begin{array}{l}\text { Ellamar } \\
\text { area }\end{array}$} \\
\hline & Mean & $\begin{array}{l}\text { Standard } \\
\text { deviation }\end{array}$ & Mean & $\begin{array}{l}\text { Standard } \\
\text { deviation }\end{array}$ \\
\hline Monocrystalline quartz & 36.4 & 8.2 & 49.2 & 7.3 \\
\hline Polycrystalline quartz & 5.7 & 3.2 & 5.3 & 0.9 \\
\hline Chert & 4.3 & 2.7 & 3.7 & 0.5 \\
\hline Plagioclase & 23.4 & 4.6 & 23.1 & 8.6 \\
\hline Potassiun feldspar & 3.5 & 3.6 & 0.8 & 1.3 \\
\hline Volcanic lithic fragments & 5.2 & 1.9 & 4.1 & 1.9 \\
\hline Sedimentary lithic fragments & 4.5 & 3.7 & 5.8 & 4.4 \\
\hline Metamorphic lithic fragments & 6.1 & 2.1 & 3.6 & 0.5 \\
\hline Plutonic lithic fragments & 0.8 & 0.9 & 0.7 & 0.4 \\
\hline Matrix and cement & 14.9 & 3.1 & 13.2 & 6.6 \\
\hline Heavy minerals & 1.1 & 0.9 & 0.8 & 0.7 \\
\hline Micas and chlorite & 8.1 & 6.2 & 2.3 & 2.2 \\
\hline Quartzose grains (total) & 50.8 & 9.7 & 60.2 & 8.4 \\
\hline Feldspar (total) & 30.8 & 7.3 & 25.4 & 9.2 \\
\hline Lithic (total) & 18.4 & 5.5 & 14.4 & 4.5 \\
\hline Chert/Total quartz & 0.09 & 0.03 & 0.07 & 0.02 \\
\hline Plagioclase/Total feldspar & 0.85 & 0.12 & 0.93 & 0.06 \\
\hline $\begin{array}{l}\text { Volcanic lithic fragments/ } \\
\text { Total lithic fragments }\end{array}$ & 0.32 & 0.11 & 0.32 & 0.24 \\
\hline
\end{tabular}


a different provenance than the Orca Group sandstones in other parts of the Prince William Sound area-a provenance in which highly evolved arc-orogen sources and subduction complexes were more important than volcanic-rich, less-evolved orogen complexes.

The sandstone of the Montague Island area (hereafter $M$ for brevity) and, to a lesser extent, that of the Ragged Mountain area (hereafter RM) are also compositionally distinguishable from sandstone in the type locality of the Orca Group (table 8, figs. 16 and 17). Samples are mostly lithofeldspathic and moderately well sorted, but some are poorly to very poorly sorted. Quartz contents are moderate (M, 2943 percent; $R M, 22-35$ percent) and $C / Q$ ratios are
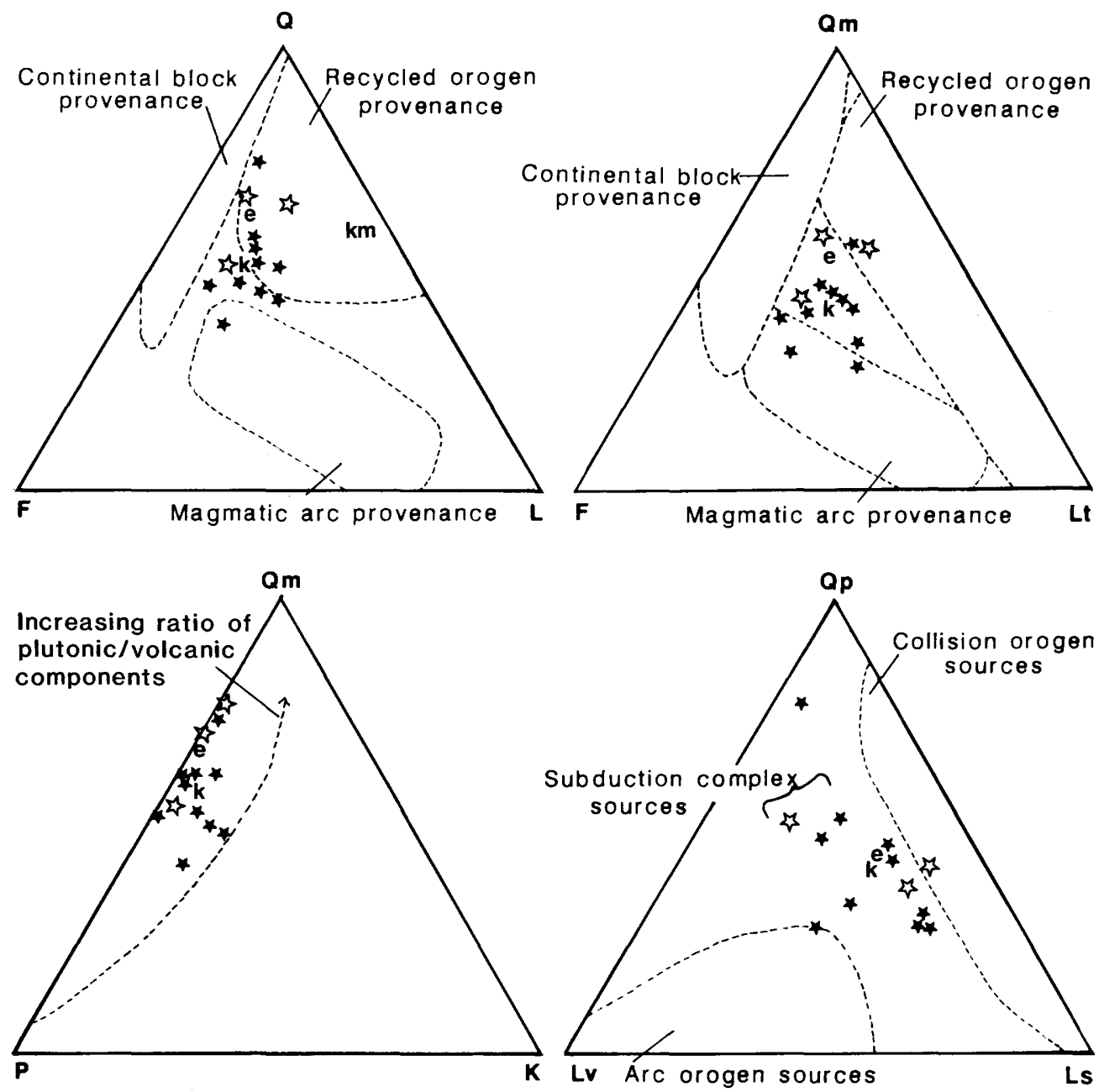

EXPLANATION

AREA

MEAN

CLAST TYPE

$\begin{array}{ccc}\text { Ellamar } & \text { e } \\ \text { Knight Island } & \mathbf{k} \\ & \text { Knight Island* }^{*} & \mathbf{k m}\end{array}$
$\begin{array}{cc}\text { Q } & \text { Total quartzose grains } \\ \text { Qm } & \text { Monocrystalline quartz }\end{array}$

Qp Polycrystalline quartz

$L$ Total lithic grains

Lt Total lithic grains and polycrystalline quartz

Lv Volcanic lithic grains

Ls Sedimentary lithic grains

F Total feldspar

P Plagioclase

K Potassium feldspar Provenance fields ${ }^{+}$

* Data from McGlasson, 1976

+ Dickinson and Suczek, 1979

Figure 15. Modal analyses of sandstone of the Orca Group from the Ellamar and Knight Island areas. 
relatively low (M, 0.06-0.23; RM, 0.03-0.09), although values for the Montague Island samples are the highest counted for this study, and total chert content is 8 percent in some Montague Island samples (fig. 12d). Feldspar contents are moderate (M, 24-40 percent; RM, 32-50 percent), and maximum potassium feldspar contents are about 15 percent in both groups. Lithic content is low (M, 13-26 percent; RM, 14-32 percent), and the $\mathrm{V} / \mathrm{L}$ ratio varies but is typically $0.2-0.3$. Volcanic lithic clasts constitute a maximum of 10 percent in both groups, with felsitic and lathwork clasts most abundant. A conglomerate $5 \mathrm{~km}$ west of Ragged Mountain, near Martin River Slough, contains more than 75 percent felsic tuff and porphyry clasts, and a coarse-grained sandstone from this area contains 24 percent felsic volcanic clasts.

At Ragged Mountain mafic volcanic clasts are abundant in coarse-grained sandstone interbedded with volcanic rocks (units Tots and Tosv of Nelson and others, 1985). Similar sandstone is present on Hawkins and Hinchinbrook Islands (unit Tosv), and south of Miles Glacier (unit Tots). (These rocks are not included in the point-count data base of this study because of their coarse grain size.) Samples contain as much as 90 percent predominantly lathwork-textured volcanic lithic clasts, as well as fossiliferous calcareous clasts not noted in any other sandstone examined in this study. A chemical analysis of one such sample from Ragged Mountain contains high levels of $\mathrm{TiO}_{2}$ (2.5 percent), $\mathrm{Fe}_{2} \mathrm{O}_{3}$ (14.2 percent), and $\mathrm{MgO}$ (5.6 percent), and relatively low $\mathrm{Si}_{2}$ (47 percent) (table 2, sample 6). These volcaniclastic sandstones may have been produced in large part by intrabasinal erosion of Orca Group mafic volcanic rocks.

Sedimentary lithic clasts (mainly mudstone and siltstone) are the dominant lithic grains in most Montague Island and Ragged Mountain samples, but metamorphic lithic grains (phyllite, schist-notably biotite schist) are also abundant, particularly in samples from western Montague Island.

Mica (biotite and lesser white mica) is particularly abundant in the Montague Island and Ragged Mountain samples. Eight Montague Island samples contain more than 8 percent mica (as much as 16 percent in one sample). The mica grains are distinguished by irregular extinction and kinking, probably a result of sediment compaction (Moore, 1973). Most samples contain garnet in the heavymineral suite; a few of the Ragged Mountain samples contain as much as 3.5 percent pyroxene and amphibole. Other heavy minerals are epidote, sphene, and zircon.

Like the Knight-Ellamar samples, Ragged Mountain and, especially, Montague Island samples define fields on the $\mathrm{Q}-\mathrm{F}-\mathrm{L}$ and $\mathrm{Qp}-\mathrm{Lv}-\mathrm{Ls}$ diagrams that overlap only slightly with fields defined by Port
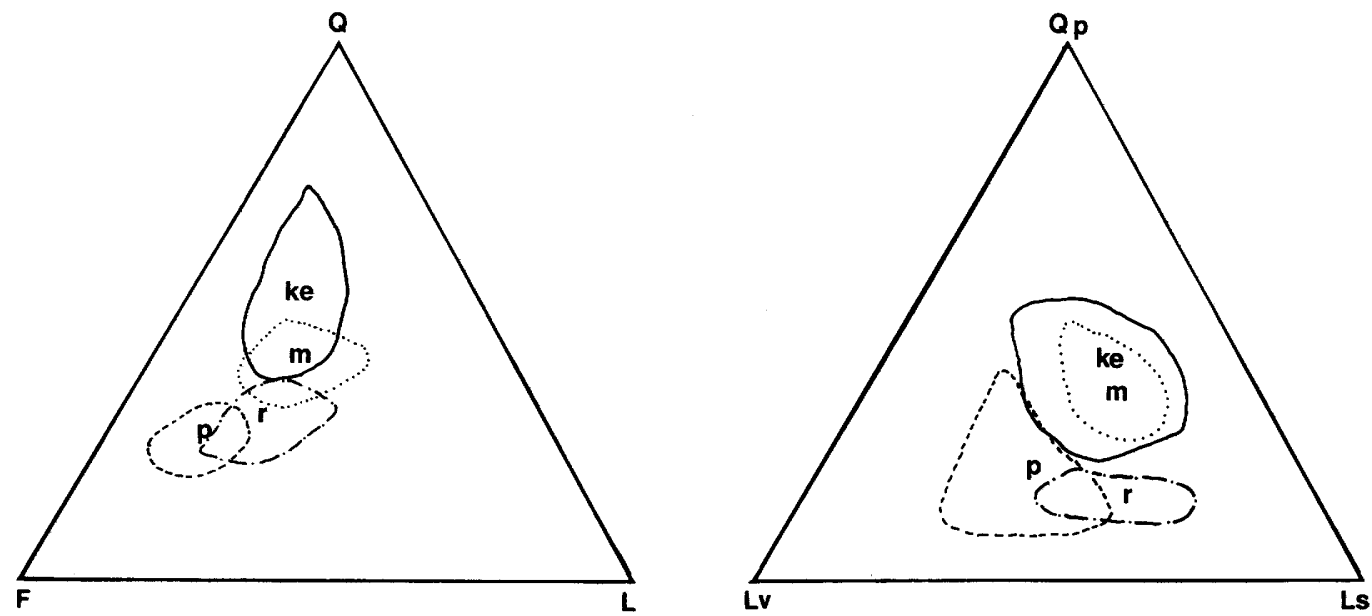

EXPLANATION

AREA

Knight Island-Ellamar

Montague Island

Ragged Mountain

Port Gravina-Cordova
FIELD

MEAN

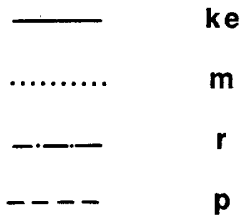

Figure 16. Comparison of modal analyses of sandstone from the Knight Island-Ellamar (combined), Montague Island, and Ragged Mountain areas with those from the Port Gravina-Cordova area. Q, total quartzose grains; F, total feldspar; L, total lithic grains; $\mathrm{Qp}$, polycrystalline quartz; Lv, volcanic lithic grains; Ls, sedimentary lithic grains. 
Gravina-Cordova samples (fig. 16). Compared to provenance fields delineated by Dickinson and Suczek (1979), Montague Island-Ragged Mountain samples fall between the arc-orogen, continental-block, and collision-orogen fields on the Q-F-L diagram and fall within the subduction-complex field on the Qp-Lv-Ls diagram (fig. 17). Discriminant analysis shows that Montague Island samples contain more quartz, biotite, and sedimentary and metasedimentary lithic clasts than do Port Gravina-Cordova samples.

\section{Comparison of Results of Studies of the Orca Group with Previous Work}

The major previous study of Orca Group sandstone petrography is that of Winkler (1976). He examined 59 samples, collected primarily from Hinchinbrook Island, but including a few samples collected from adjacent islands and the mainland. On the Q-F-L diagram, his results encompass the fields delineated by both the Port Gravina-Cordova and the Montague Island-Ragged Mountain samples of this study (figs. ll and 17; table 4). Winkler determined a mean Q-F-L of 43-46-11 for his samples-slightly more quartz-rich than the Montague Island samples of this study, and slightly poorer in lithic components than the Port Gravina-Cordova samples. The $C / Q$ ratio is close to that determined for the Montague Island area, and the $\mathrm{P} / \mathrm{F}$ and $\mathrm{V} / \mathrm{L}$ ratios are higher than those determined for the Montague Island, Ragged Mountain, or Port Gravina-Cordova areas.

Comparison of Winkler's (1976) findings to those of this study is hampered by the fact that only about one-quarter of his samples are medium grained-the rest are fine and very fine grained. Other geologic considerations (discussed below) indicate that rocks of Hinchinbrook Island may have more similarities with those of the Montague Island-Ragged Mountain areas than with those of the Port Gravina-Cordova region. As mentioned above, the results of McGlasson's point counts of Knight Island samples agree fairly well with the findings of the present study in that area.

Petrographic information about rocks correlative with the Orea Group is available from the Ghost Rocks Formation (Winkler, in Nilsen and Moore, 1979) and the Sitkalidak Formation (Winkler, in Nilsen and Moore, 1979; Moore and others, 1983). Eight samples were studied from the Ghost Rocks Formation; the mean QF-L (21-37-42) is most like that of the samples from the Sargent Icefield area of this study. The Ghost Rocks samples are, however, more lithic rich in general, and more volcanic lithic rich in particular $(V / L=0.95)$ (table 5). Samples collected from the Sitkalidak Formation show striking similarities to those of the Montague Island and Ragged Mountain areas, as will be discussed more fully below.

\section{TECTONIC MODELS AND THE PLACEMENT OF THE VALDEZ-ORCA BOUNDARY}

One goal of this study was to test whether the petrographic distinction that previous workers suggested existed between sandstones of the Valdez and Orca Groups could be shown to exist throughout the Prince William Sound area, and thus could help to resolve the problem of placement of the contact between the two groups. The results of this study indicate that there is no petrographic break in sandstone composition across the Contact fault as presently mapped.

A second goal was to test the concept that the Valdez and Orca Groups comprise separate tectonostratigraphic terranes. To what extent can sandstone-composition analyses for the two groups constrain the tectonic scenarios evoked to explain their present structual settings?

Jones and others (1981, p. 1) defined a tectonostratigraphic terrane as "a fault-bounded geologic entity, usually of regional extent, that is characterized by a distinctive stratigraphic sequence or rock assemblage that differs markedly from those of nearby partly or entirely coeval neighbors." Terrane analysis must consider the total record of sedimentation and structural history up until the time of accretion.

Some previous workers treated the Valdez and Orca Groups (and their correlative sequences) as terranes in the sense described above-that is, thick accretionary wedges derived from different sources and accreted to the continent in two discrete episodes. For example, Plafker and others (1977) stated that the Chugach terrane (Valdez Group and correlative units) was accreted to the continental margin along the Border Ranges fault system by latest Cretaceous time (fig. 1). Consequently, the Contact fault system is interpreted as a more southerly plate boundary against which the Prince William terrane (Orca Group and correlative units) was accreted during early Tertiary time (Winkler and Plafker, 1975, 1981).

Various sources have been proposed for the protoliths of the Chugach terrane. Zuffa and others (1980) suggested that at least some of the detritus comprising Chugach terrane flysch may have been derived from older, previously accreted terranes, such as Wrangellia, or from the melange part of the Chugach terrane-for example, the McHugh or Uyak Complexes. Decker (1980) agreed, stating that the Kelp Bay Group (a southeastern correlative of the McHugh Complex) may have been a source for some of the felsitic material deposited in the Sitka Graywacke. He also considered a basalt-rhyolite belt of Triassic age in the Alexander terrane as a possible source, but concluded that it was probably volumetrically incapable of supplying the entire Chugach terrane.

Nilsen and Zuffa (1982) suggested that the Chugach terrane and adjacent terranes to the north, including the Peninsular terrane and Wrangellia, formed a single "megaterrane" that moved north as a unit. They proposed derivation of Chugach terrane flysch from the magmatic arc and adjacent shallow marine forearc basin of the Peninsular terrane. Pavlis (1982) suggested that the mid-Cretaceous GravinaNutzotin magmatic arc in the Talkeetna "superterrane" (a composite of Wrangellia and the Peninsular and Alexander terranes) was a source and accounted for the present mismatch of nearly $1,000-$ $\mathrm{km}$ between this source and the distribution of Chugach terrane flysch by later large-scale 
intraterrane faulting. Winkler and Plafker (1981) agreed that Chugach terrane strata may have been originally deposited far to the south, then tectonically transported northward, but they were unable to identify a source terrane.

A commonly cited source for the Orca Group (Prince William terrane) is the plutonic and high-grade metamorphic complex of the Coast Mountains of British Columbia and southeastern Alaska. First suggested by Hollister (1979), the idea was adopted by Helwig and Emmet (1981) and Winkler and Plafker (1981). However, as Helwig and Emmet pointed out, a possible flaw in this argument is an apparent mismatch of the age of the Orca protolith with its proposed source. The maximum uplift of the coastal metamorphic and plutonic belt occurred 47-52 $\mathrm{Ma}$ (Hollister, 1979). This is slightly younger than the age of the Orca Group if the age (50.5-53.5 $\pm 1.6 \mathrm{Ma})$ of the plutonic belt that intrudes the northern parts of the Orca is taken as a minimum age limit for the entire group.

\section{Evidence for the Northward Displacement of the Valdez and Orca Groups}

Paleomagnetic data may provide further constraints on possible source areas for the Valdez and Orca Groups. Most of the paleomagnetic studies published to date support the idea that both groups were originally deposited south of their present positions relative to North America, but how far south and during what period northward movement occurred remain uncertain.

Gromme and Hillhouse (1981) examined two gabbro plutons in the Chugach terrane of probable Paleogene age in the Fairweather Range in southeastern Alaska, as well as sheeted mafic dikes and pillow basalt of the Resurrection Peninsula. The mafic complex of the Resurrection Peninsula is of uncertain age, however, and is in probable fault contuct with the sedimentary rocks of the Valdez Group. Gromme and Hillhouse concluded that the entire Chugach terrane has moved $25^{\circ}-26^{\circ}$ northward and that this movement took place between 20 and 41 Ma. This would require a minimum rate of crustalplate motion slightly higher than the upper limit of contemporary absolute plate velocities.

Stone and others (1982) presented paleomagnetic data from sedimentary rocks in the western part of the Chugach terrane (the Shumagin and Kodiak Formations). Their results indicate that at $70 \mathrm{Ma}$ the paleolatitude of the Chugach terrance was between $6^{\circ}$ and $32^{\circ}$ N., and that the terrane reached its present position at some time in the late Tertiary through consistent northward movement from Late Cretaceous time until the present.

Both of these scenarios seem to conflict with a Late Cretaceous or early Paleocene time of emplacement for the Chugach terrane, unless the terrane were emplaced against the continental margin far to the south and then moved northward by dextral transform faulting. Cowan (1982) suggests that such a mechanism has displaced parts of the Chugach terrane as much as $1,100 \mathrm{~km}$ northward since early Tertiary time.

Paleomagnetic evidence from the Prince William terrane also indicates a southern origin. Stone and others (1982) obtained paleomagnetic data from sedimentary rocks of the Sitkalidak and Ghost Rocks Formations. They postulated a paleolatitude for these rocks between $21^{\circ}$ to $28^{\circ} \mathrm{N}$. at about 40-50 Ma.

Plumley and others (1983) presented results of a detailed paleomagnetic study of a series of volcanic flows interlayered with sedimentary rocks of the Ghost Rocks Formation. They concluded that, since $62 \mathrm{Ma}$, these rocks have been transported $25^{\circ}$ north from a paleolatitude of $40.3^{\circ} \mathrm{N}$. $\pm 6.2^{\circ}$. Moore and others (1983), using paleomagnetic data and other geologic constraints, suggest that the Prince William terrane was emplaced near its present latitude by $45 \mathrm{Ma}$.

Another paleomagnetic study of the Prince William terrane (Hillhouse and Gromme, 1977) examined the sheeted dikes and pillow basalts of Knight Island. The results of the investigation were equivocal, but provided no compelling evidence for long-distance transport of the rocks of the Orca Group. Plumley and others (1983), however, proposed that the equivocal results may reflect the incomplete elimination of secondary magnetic components. The only other paleomagnetic data available from the Prince William terrane are the preliminary results of Plumley and Plafker (1985) from Galena Bay in the central Prince William Sound area. These results (discussed below) indicate that as much as $40^{\circ}$ of northward movement has occurred since the Paleogene for at least part of the Prince William terrane.

Paleontologic data also indicates that the Prince William terrane may have undergone significant northward transport. The sparse foraminiferal assemblages of Paleocene and early to middle Eocene age from the Orca Group contain some tropical to subtropical faunal elements (Plafker and others, 1985a). However, the basal core sample (a claystone interpreted to be a stratigraphic unit of the Prince William terrane) obtained from the Middleton Island borehole contains a late middle Eocene, low-diversity microfossil assemblage indicative of a cold-water environment. These findings indicate that the Prince William terrane had reached high latitudes $\left(50^{\circ} \pm 5^{\circ}\right.$ N.) by 40-42 $\mathrm{Ma}$ (Keller and others, 1984).

Plumley and others (1983) summarized the results of paleomagnetic studies from lower Tertiary rocks of the Peninsular terrane. Although the uncertainties are large, these authors determined a mean paleolatitude of $37^{\circ} \mathrm{N}$. at about $57 \mathrm{Ma}$ for these samples.

Thus, most available paleomagnetic data from the Peninsular, Chugach, and Prince William terranes support the idea of considerable northward movement since early Tertiary time. The interpretations of Plumley and others (1983) further indicate that all three terranes were at about the same paleolatitude during early Tertiary time; these authors argued that at least the Chugach and Prince William terranes appear to have been effectively tied together by early Paleocene time. Other authors have proposed that the Peninsular and Chugach terranes have been linked since the Cretaceous (Pavlis, 1982; Stone and others, 1982). 
Petrographic Constraints on the Significance and Location of the Valdez-Orca Boundary

Can petrographic data from Prince William Sound place any constraints on these tectonic scenarios? The petrographic similarity of sandstone from the westernmost part of the Orca Group (the Sargent Icefield area) and the adjacent part of the Valdez Group (the central Valdez area) argue against the existence of a major terrane boundary at the Contact fault in western Prince William Sound. In addition to their petrographic similarity, these rocks show no differences in metamorphic history and no fossil evidence for an age difference, as discussed above.

Similar congruence in sandstone composition is evident across the Chugach-Prince William terrane boundary on Kodiak Island (fig. 1). Winkler (in Nilsen and Moore, 1979) studied samples from the Kodiak and Ghost Rocks Formations (Valdez and Orca Group correlatives, respectively) and found a complete overlap in the composition of samples from the two formations. Both groups of samples were relatively rich in volcanic lithic clasts (Kodiak Formation, mean $\mathrm{Q}-\mathrm{F}-\mathrm{L}=24-32-44, \mathrm{~V} / \mathrm{L}=0.96$; Ghost Rocks Formation, mean $\mathrm{Q}-\mathrm{F}-\mathrm{L}=21-37-42, \mathrm{~V} / \mathrm{L}=0.95)$.

Three possible conclusions follow from this petrographic similarity across the Contact fault. (1) There is no major terrane boundary between rocks presently assigned to the Chugach and Prince William terranes; both the Valdez and Orca Groups were derived from a single evolving source. (2) There is a major terrane boundary, but, at least in the western part of Prince William Sound, it is not located along the Contact fault. If this terrane boundary is to separate Cretaceous from Paleogene rocks, it would have to fall somewhere between the Contact fault and the Orca-Valdez contact as mapped by Grant and Higgins (1910) and Moffit (1954) (fig. 4). (3) There is a terrane boundary along the Contact fault; petrographic similarities on both sides of this terrane boundary, as well as indications of derivation from a continuously evolving source across this boundary, reflect interleaving of Valdez and Orca Group sandstones as imbricate fault slices, or are fortuitous or artifacts of insufficient data-set size.

\section{The Existence of a Terrane Boundary}

I believe the petrographic data best supports the first conclusion; that is, there is no terrane boundary (in the sense of a break that separates discrete packages of rocks that have distinct geologic histories) between the Valdez and Orca Groups in western Prince William Sound. Rather, the Valdez and Orea Groups constitute a single package, derived episodically or continuously from a single evolving arc orogen during Late Cretaceous into Eocene time.

The tectonic model that best fits this scenario is an early linkage of the Peninsular terrane and the Chugach-Prince William (composite) terrane, the Peninsular terrane being the source of Chugach-Prince William terrane protoliths. The sediment source for the Valdez and Orca Groups would not be affected by subsequent movement of the megaterrane because the terranes would be linked prior to the Late Cretaceous; sediment generation could occur during northward migration. Alternatively, sediment generation could have occurred prior to accretion, perhaps with later intraterrane dismemberment through large-scale strike-slip faulting, as suggested by Pavlis (1982).

If, however, the Peninsular and Chugach-Prince William terranes were not linked throughout Cretaceous and early Tertiary time, then the source of the parts of the Valdez and Orca Groups deposited prior to $62 \mathrm{Ma}$ must lie somewhere along the North American Pacific coast-between the current latitudes of southern Washing ton and southern California, if one accepts the paleomagnetic constraints of Plumley and others (1983). (This set of circumstances would exclude the plutonic-metamorphic complex of British Columbia and southeastern Alaska as a possible source of Chugach-Prince William protoliths.) One drawback of this scenario is that if the Chugach-Prince William terrane were moving throughout its depositional history (Late Cretaceous into Eocene), but its source were not attached to it (as in the first scenario), one would expect to see greater diversity and less systematic distribution of sandstone compositions than is observed in the Valdez-Orca package.

\section{Alternative Locations of a Terrane Boundary}

The petrographic data from this study could also support the second conclusion-that a major terrane boundary does exist, but it is not located along the Contact fault in western Prince William Sound. Four possible alternative locations of this boundary will be considered: the Johnstone Bay fault of Tysdal and Case (1979), the Bainbridge fault of Helwig and Emmet (1981), the Montague Strait fault of Tysdal and Case (1979), and the Placer River fault (Tysdal and Case, 1979).

\section{Johnstone Bay Fault}

Adopting the Johnstone Bay fault as the terrane boundary (Plafker and others, 1977) would have the following positive consequences: (1) It would include the gold-bearing rocks south of Sargent Icefield (presently assigned to the Orcu Group) in the Valdez Group, which contains all other similar gold-bearing rocks presently known (Nelson and others, 1984); (2) It would place the only major area of mid-greenschist facies rocks known in the Orca Group of western Prince William Sound in the same terrane as adjacent mid-greenschist facies rocks of the Valdez Group (M.L. Miller, written commun., 1985).

However, according to Tysdal and Case (1979, p. $10)$, the Johnstone Bay fault is a minor structure marked by "a zone of breccia a few tens of meters wide." Although Condon and Cass (1958) suggested that, on the basis of aerial photo interpretation, the fault was connected with a smaller fault north of Icy Bay, Tysdal and Case could not confirm this connection. Such a minor discontinuous structure does not seem likely to represent a terrane boundary. In addition, although this boundary would group the most lithic-rich of the Orca Group samples with the lithic- 
rich Valdez Group, no distinct petrographic boundary can be drawn between the sandstone of the Sargent Icefield area and that of the adjacent Chenega area.

\section{Bainbridge Fault}

A second candidate for the terrane boundary is the Bainbridge fault of Helwig and Emmet (1981). This would be similar to the Valdez-Orca contact proposed by Moffit (1954). The Bainbridge fault is described as a westward-dipping thrust fault that places massive sandstone on top of cataclastically deformed thinner bedded rocks (Helwig and Emmet, 1981). Adoption of this boundary has the following advantages: (1) It coincides approximately with the mafic belt that runs from Elrington Island, through Knight Island, and north to Glacier Island; (2) It separates distinct petrographic assemblages-the quartz-rich rocks of the Knight Island area and the more feldspatholithic rocks of the Chenega area; (3) Use of this fault as the terrane boundary would put all the plutonic rocks on the west and northwest side of the boundary -that is, in the Valdez Group. Using the Bainbridge fault as a terrane boundary would eliminate any conflict in western Prince William Sound between fossil assemblages of late middle and late Eocene age reported from localities in southern parts of the Orca Group (Plafker and others, 1985a and b) and the 50.5$53.5 \pm 1.60-\mathrm{Ma}$ age of the oldest group of plutons.

\section{Montague Strait Fault}

A third possible terrane boundary is the Montague Strait fault. As discussed further below, this fault separates rocks of lower metamorphic grade to the east from slightly higher grade rocks to the west, but the difference in grade is not striking. Also, the petrographic distinction between sandstone of the Knight Island area and that of the Montague Island area is not sharp.

\section{Placer River Fault}

The fourth possible terrane boundary is the Placer River fault. Because both Late Cretaceous pelecypod assemblages that have been found between it and the Contact fault to the east are float occurrences, the rocks in this area may be thought of as of uncertain age. However, geologists mapping in the Anchorage quadrangle (Winkler, written commun., 1985) have found Late Cretaceous pelecypods in place east of Lake George. This is east of the projected trace of the Placer River fault, but only by about 5 $\mathrm{km}$. The trace of this fault is marked by a shear zone 50-150 $\mathrm{m}$ wide, and rocks adjacent to the fault have a well-developed schistose fabric (Tysdal and Case, 1979). Although rocks west of the Placer River fault (west Valdez area) are richer in lithic grains (particularly volcanic lithic grains) than are rocks east of the fault (central Valdez area), this petrographic distinction is not as sharp as that marked by the Bainbridge fault (tables 1,5 , and 7 ; figs. 6,13 , and 15). Thus, if a boundary between the Orca and Valdez
Groups is to be selected to reflect petrographic distinctions, the Bainbridge fault of Helwig and Emmet (1981) seems to be the best choice.

\section{Imbricate Faulting along the Terrane Boundary}

If the Contact fault is a major terrane break, the petrographic similarity of rocks on either side of the fault may be the result of the presence of interleaved slices of Valdez and Orea Group sandstones. This interleaving would be reflected in the rocks of the Sargent Icefield, and perhaps the Chenega, areas, where the petrographic characteristics are intermediate between those of rocks in the western and central Valdez areas and rocks at the type locality of the Orca Group (Port Gravina-Cordova area). According to Winkler and others (1984), the Eagle River fault, which separates the McHugh Complex from the Valdez Group in the Seward and Anchorage quadrangles, is an example of such a zone of imbricate slivers of two units.

The reconnaissance nature of studies that have been conducted in the Sargent Icefield area and the difficult terrain mean that an imbrication zone marking the Orca-Valdez contact in this area cannot be ruled out. As described above, however, rocks of the Sargent Icefield area represent an internally coherent and distinctive lithologic belt of massive sandstone and, to the north, slump deposits and conglomerate (Helwig and Emmet, 1981; Nelson and others, 1985). These lithologies are distinct from the dominantly thin-bedded and shale-rich facies that are present to the west in the central Valdez area and to the east in the Chenega area. Thus, the lithologic continuity of the Sargent Icefield area argues against explaining its transitional petrographic character as a result of tectonic mixing.

\section{Summary}

The results of petrographic studies of the sandstone in the western part of Prince William Sound are best explained by one of two possible tectonic reconstructions. (1) There is no terrane boundary in western Prince William Sound, and the Valdez and Orca Groups might best be thought of as a single flysch sequence derived from one continuously evolving source during Late Cretaceous, Paleocene, and Eocene time. The magmatic arc of the Peninsular terrane represents one possible source. (2) The Bainbridge fault of Helwig and Emmet (1981) separates the Cretaceous (and lower Paleogene ?) age lithic-rich sedimentary rocks of the Chugach terrane from the Paleogene, relatively quartz- and feldspar-rich sedimentary rocks of the Prince William terrane. Protoliths of the Chugach terrane were derived primarily from a volcanic arc; protoliths of the Prince William terrane were derived, at least in part, from the more evolved roots of an arc. The plutonicmetamorphic complex of the Coast Mountains may represent this source, particularly if the Orca Group is, at least in part, slightly younger than the intrusive belt (50.5-53.5 $\mathrm{Ma})$ in Prince William Sound, a possibility that will be discussed further below. 


\section{AREAS THAT HAVE ANOMALOUS SANDSTONE PETROGRAPHY}

\section{Mount Denson Area}

The Mount Denson area, in the northwestern part of the Cordova quadrangle (figs. 4 and 5), is underlain by rocks presently assigned to the Valdez Group. The composition of sandstone in this area is anomalous relative to that of sandstones in other areas where the Valdez Group is present.

As described above, framework-grain mode diagrams and discriminant analyses show no overlap in composition between the Mount Denson-area samples and samples from the west, central, or east Valdez areas, but they do show a complete overlap with samples from the adjacent Port Gravina-Cordova area, the type locality of the Orca Group. No sandstone samples collected from north of the Jack Bay fault (fig. 5) were available for analysis during the course of this study, so the petrographic character of these rocks is not known.

The petrographic character of the Mount Denson samples has several possible explanations. Like the congruence in sandstone composition on both sides of the Contact fault in the western Prince William Sound area, this may be evidence that in the eastern part of the sound as well, the Contact fault does not separate two discrete packages of rock with distinct sources and geologic histories. Instead, both the Orca and Valdez Groups may be part of a single package faulted and deformed since its deposition. A second possibility is that the actual contact between the Orca and Valdez Groups is not the Landlock strand of the Contact fault, as presently mapped (Winkler and Plafker, 1981; Nelson and others, 1985), but lies further north-perhaps along the Jack Bay fault.

The existence of the Landlock fault (fig. 5) was first proposed by Capps and Johnson (1915, p. 33), who described it as "inconspicuous, for it runs parallel to the bedding of the slates and graywackes of the Valdez Group and also lies parallel to the surface of the geeenstone of the Orca Group***giving the rocks a deceptive appearance of stratigraphic conformity." They believed, however, that "there can be little question that the fault exists", since it juxtaposes younger rocks with those "of much greater age" (p. 33).

No fossils have been found in the Mount Denson area to confirm or refute the supposition that these rocks are older than adjacent rocks southwest of the Landlock fault. In the absence of paleontologic data, metamorphic-grade differences have been used to argue that Mount Denson-area rocks are older than rocks to the south (Capps and Johnson, 1915). However, no significant grade difference exists between rocks in the northern part of the Mount Denson area (including the samples point-counted for this study) and those southwest of the Landlock fault; rocks in both areas are of prehnite-pumpellyite to low greenschist facies (M.L. Miller, written commun., 1985). Higher-grade (amphibolite facies) rocks occur southeast of Mount Denson, but these rocks reflect low pressure, high-temperature metamorphism, possibly produced by a buried pluton (M.L. Miller, written commun., 1986), and need not be older than adjacent lower-grade rocks.

Winkler and Plafker (1975) adopted the Landlock fault as a segment of the Contact fault system, which they interpreted as a "major early Tertiary plate boundary." However, the trace of the Landlock segment varies from sinuous to linear, and its shallow dip (about $45^{\circ}$ N.) is anomalous for the Contact fault system (Winkler and Plafker, 1981). It also represents a distinct southward jog in the regional trace of the Contact fault system.

Adoption of the Jack Bay fault as the contact between the Orca and Valdez Groups would have several advantages. It would eliminate the southward jog in the master Contact fault system, and it would keep rocks of essentially equivalent petrographic character together in a single group (the Orca Group). Furthermore, the Jack Bay fault has a steeper dip, more in keeping with the rest of the Contact fault system.

\section{Areas Spatially Associated with Mafic Rocks}

Other rocks in the Prince William Sound area that have anomalous compositions are spatially associated with mafic rocks. These rocks include sandstones currently assigned to the Valdez Group (in the Resurrection Peninsula area) and sandstones currently assigned to the Orca Group (in the Knight Island and Ellamar areas).

\section{Resurrection Peninsula Area}

The relation between the mafic complex of the Resurrection Peninsula and the spatially associated sedimentary rocks has been interpreted in various ways. Tysdal and others (1977) stated that the mafic igneous rocks of the peninsula intrude and are interbedded with flysch typical of the Valdez Group. Nelson and others (1985) mapped the relation as a thrust fault that places flysch above interbedded pillow basalt, broken pillow breccia, and minor amounts of siltstone and argillite. Even if the mafic complex-sedimentary rock contact is interpreted as a thrust fault, the two units could still be contemporaneous but have suffered post-formational faulting. Without age control, the stratigraphic relation of the mafic complex and the adjacent sedimentary rocks remains equivocal.

The anomalous composition of the sandstone of the Resurrection Peninsula area relative to other Valdez Group sandstones has several possible explanations. If the sandstone samples collected from the Resurrection Peninsula are considered to be part of the mafic complex and in fault contact with typical Valdez Group flysch, they may have had a separate source and different subsequent history from that of the flysch, or they may have a different composition as a result of barrier effects produced by local volcanic edifices. If the sandstone of the Resurrection Peninsula is a part of the Valdez Group-flysch package, two interpretations might be advanced to explain its anomalous composition. As mentioned above, the finer grain size and slightly better sorting 
of these samples may indicate that sedimentary processes (such as reworking and winnowing) have altered the original composition. Alternatively, local volcanic centers may have greatly influenced Valdez Group sedimentation, as suggested by Mitchell (1979). Quartzofeldspathic sandstones-like those reported from the southwestern Kenai Peninsula by Cowan and Boss (1978) and those of the Resurrection Peninsulacould have accumulated in areas distal to these volcanic centers.

\section{Knight Island Area}

The Knight Island samples of this study are also in an equivocal tectonic relation to the adjacent mafic complex. McGlasson (1976) suggested that the sedimentary rocks are in tectonic contact with the gabbro on the east side of Knight Island and are interbedded with the pillow-basalt sequence on the west side of the island. Tysdal and Case (1979) indicated that the mafic rocks are in depositional or intrusive contact with the sedimentary rocks on both sides of the island. Nelson and others (1984), however, considered the contact to be a structural one throughout its extent.

Striking lithologic similarities between the mafic complexes of Resurrection Peninsula and Knight Island, as well as the lack of conclusive age determinations for either complex, allow one to speculate that the two sequences were originally part of a single mafic complex. Whole-rock greenstone $\mathrm{K}$ Ar ages may not support this idea (Winkler and others, 1984). These ages, considered useful in dating thermal events related to accretionary or collisional processes, indicate that the ages of the rocks of the Resurrection Peninsula were reset at about 47-50 Ma, 10-14 million years earlier than the rocks of Knight Island. However, this resetting may be only partial, so the radiometric data do not resolve the question of the relative ages of the two mafic complexes, or even the question of their time of emplacement.

The petrographic character of the sandstones of Knight Island and Resurrection Peninsula also indicates the differences between the two sequences, although, as detailed above, the sandstone now spatially associated with the mafic complexes may not be cogenetic with these complexes. Although the sandstone from both areas is relatively lithic poor, the Knight Island samples contain more quartz and less feldspar than do the Resurrection Peninsula samples.

\section{Ellamar Area}

There is nothing equivocal about the association of the Ellamar-area sandstone with the adjacent volcanic rocks. All three Ellamar samples are from sandstone lenses 5-7 $\mathrm{m}$ thick that are clearly interbedded with pillowed and massive basalts. Mafic rocks are volumetrically dominant in the Ellamar area, comprising 75-92 percent of two sections measured by Nelson and others (1985).
The sandstones of the Ellamar area, like those of the Resurrection Peninsula, are at the lower end of the medium grain-size classification, and are also the best-sorted samples of any examined in this study. Knight Island samples, however, are neither particularly well sorted nor fine grained.

The Ellamar and Knight Island-area rocks may be part of a single package of sedimentary and mafic rocks distinct from the rest of the Orca Group. Nelson and others (1984) described an arcuate gravity and aeromagnetic high that trends northeastward from Elrington Island through Latouche and Knight Islands, runs eastward through Glacier Island and the Ellamar area, and then continues east across the Contact fault to the mountains south of the Tasnuna River. This gravity and aeromagnetic pattern roughly coincides with a belt of mafic volcanic rocks. Sandstone intercalated with this volcanic belt has a composition distinct from that of sandstone to the nor thwest and southeast and could constitute a separate petrographic province. The composition could reflect either a distinct provenance or the blocking effect of volcanic edifices. The particularly quartz-rich nature of the Ellamar samples, along with their finer grain size and well-sorted texture, may indicate concentration through reworking of an already quartz-rich sediment.

One line of evidence that supports the theory that the Ellamar rocks, at least, are part of a package separate from the rest of the Orca Group is the paleomagnetic data from the Galena Bay area (Plumley and Plafker, 1985), 3-10 km north of the Ellamar sandstone-sample localities. The paleomagnetic data, obtained from pillow-lava flows interbedded with sedimentary rock units, indicate an inclination far shallower than expected and may imply a poleward translation of these rocks of as much as $40^{\circ}$ since Paleogene time. In contrast, the Prince William terrane is thought to have had at most $25^{\circ}$ of northward translation (Plumley and others, 1983). The volcanic rocks in the Ellamar area are also distinctive in that they lack the positive magnetic anomaly characteristic of other volcanic rocks of Prince William Sound; this may be the result of metamorphic alteration (Winkler and Plafker, 1981), but could also indicate that the Ellamar volcanic rocks represent a thin fault slice of no great vertical extent.

\section{Montague Island and Ragged Mountain Areas}

Orca Group sandstones from the Montague Island area and, to a lesser degree, from the Ragged Mountain area, are in many respects similar to sandstones of the Sitkalidak Formation that crop out along strike to the southwest in the Sitkalidak Island area (fig. 1). Stewart (1976) suggested that the Sitkalidak Formation is the proximal equivalent of sediments that comprise the Zodiac fan, located about $400 \mathrm{~km}$ southwest of Sitkalidak Island on the Aleutian abyssal plain. Winkler (in Nilsen and Moore, 1979) disagreed, asserting that the Sitkalidak sandstones are too rich in volcanic detritus to correlate well with the Zodiac sands. Moore and others (1983) presented more extensive petrographic data from the Sitkalidak Formation and argued that, particularly on the basis of 
Q-F-L and V/L ratios, the Sitkalidak sandstones do correlate well with Zodiac fan sands. Sandstones from the Montague Island and Ragged Mountain areas are similar in composition and age to Sitkalidak sandstones and Zodiac fan sands. In addition, the rocks of the Montague Island-Ragged Mountain-area and the Sitkalidak Formation fall within similar sedimentary and metamorphic facies, and possess similar structural styles.

\section{Petrography}

Table 8 and figures 17 and 18 show modal data, Q-F-L plots, and V/L ratios for sandstone from the Montague Island and Ragged Mountain areas compared to data from the Sitkalidak Formation and the Zodiac fan. Using the criteria of Moore and others (1983), the Montague Island and Ragged Mountain samples correlate well with the Sitkalidak and Zodiac fan samples. In fact, Montague Island sandstone correlates even more closely with the Zodiac fan sediments than do the Sitkalidak sandstones. The Montague Island and Ragged Mountain samples have an average grain size of about $0.3 \mathrm{~mm}$, slightly coarser than in the Zodiac samples of Stewart (1976) or the Sitkalidak samples of Moore and others (1983), which are fine grained (average grain size between 0.15 and $0.25 \mathrm{~mm}$ ). Compositional variation due to such modest differences in grain size is, however, unlikely to be extensive or to invalidate the general petrographic similarities between the Montague Island, Ragged Mountain, Sitkalidak Formation, and Zodiac fan samples.
The age of the Sitkalidak Formation is thought by Moore and Allwardt (1980) to be Eocene. The Sitkalidak is not intruded by the plutons $(56-64 \mathrm{Ma})$ that intrude the adjacent Ghost Rocks Formation and is overlain by the nonmarine Sitkinak Formation of Oligocene age. The most reliable age-diagnostic fossil known from the Sitkalidak is a crab that occurs most abundantly in rocks of late Eocene age (Moore and Allwardt, 1980) in western Washing ton.

The Zodiac fan sediments contain a sparse nannoflora of late early, middle, and late Eocene age (Stewart, 1976).

Sparse fossil data indicate that the southeastern parts of the Orca Group are younger than the rest of the group, and may be younger than the plutonic belt that intrudes the more northern Orca Group exposures. Fossil localities at eastern Montague Island, the southern part of the Ragged Mountain area, and Hinchinbrook Island (fig. 4) have yielded radiolarians, coccoliths, dinoflagellates, and foraminifers thought to be of middle middle through late Eocene age (Plafker and others, 1985a). Fossils found elsewhere in the Orca Group are of Paleocene to earliest middle Eocene age (Tysdal and Case, 1979; Plafker and others, 1985a,b).

Some of the middle and late Eocene fossils occur adjacent to or in the same samples as Paleocene or early Eocene forms. Plafker and others (1985b) suggested that the younger age assignments reflect either misidentification of poorly preserved, sparse assemblages or problems with the age ranges of certain fossils. However, at least some of the

Table 8.--Composition of sandstone of the Orca Group from the Montague Island ( $n=12)$ and Ragged Mountain ( $\mathrm{n}=7)$ areas

[Gitkalidak Formation data $(n=27)$ from Moore and others (1983). See table 1 for explanations of parameters. See figure 17 for graphic presentation of data]

\begin{tabular}{|c|c|c|c|c|c|c|}
\hline \multirow[b]{3}{*}{ Monocrystalline quartz } & \multicolumn{2}{|c|}{$\begin{array}{c}\text { Montague Island } \\
\text { area }\end{array}$} & \multicolumn{2}{|c|}{$\begin{array}{l}\text { Ragged } \\
\text { Mountain } \\
\text { area }\end{array}$} & \multicolumn{2}{|c|}{$\begin{array}{l}\text { Sitkalidak } \\
\text { Formation }\end{array}$} \\
\hline & Mean & $\begin{array}{l}\text { Standard } \\
\text { deviation }\end{array}$ & Mean & $\begin{array}{l}\text { tandard } \\
\text { viation }\end{array}$ & Mean & $\begin{array}{r}\text { Standard } \\
\text { deviation }\end{array}$ \\
\hline & 26.2 & 5.2 & 24.6 & 5.1 & 17.4 & 3.6 \\
\hline $\begin{array}{l}\text { Polycrystalline quartz } \\
\text { Chert }\end{array}$ & $\begin{array}{l}5.9 \\
4.2\end{array}$ & $\begin{array}{l}1.8 \\
1.8\end{array}$ & $\begin{array}{l}2.0 \\
1.6\end{array}$ & $\begin{array}{l}0.7 \\
0.6\end{array}$ & $\begin{array}{l}5.8 \\
0.9\end{array}$ & $\begin{array}{l}3.9 \\
1.1\end{array}$ \\
\hline Plagioclase & 24.3 & 4.6 & 33.6 & 6.7 & 19.1 & 5.4 \\
\hline Potassium Feldspar & 4.9 & 4.4 & 8.6 & 4.0 & 3.2 & 1.6 \\
\hline Volcanic lithic fragments & 6.6 & 2.0 & 6.5 & 2.7 & 11.1 & 4.6 \\
\hline Sedimentary lithic fragments & 7.9 & 3.4 & 11.0 & 5.4 & 12.2 & 4.6 \\
\hline Metamorphic lithic fragments & 4.7 & 1.8 & 3.1 & 2.4 & 3.5 & 3.0 \\
\hline Plutonic lithic fragments & 1.1 & 0.8 & 1.6 & 1.0 & 2.8 & 1.4 \\
\hline Matrix and Cement & 13.4 & 4.2 & 15.2 & 4.4 & 20.9 & 4.0 \\
\hline Heavy minerals & 1.3 & 0.6 & 2.0 & 0.9 & 0.6 & 0.9 \\
\hline Micas and chIorite & 11.4 & 5.0 & 3.2 & 1.9 & 1.9 & 1.2 \\
\hline Quartzose grains (total) & 41.5 & 4.8 & 30.2 & 4.8 & 31.6 & 6.3 \\
\hline Feldspar (total) & 34.6 & 6.1 & 46.0 & 8.2 & 29.7 & 10.1 \\
\hline Lithics (total) & 23.9 & 5.7 & 23.8 & 6.4 & 38.6 & 9.3 \\
\hline Chert/Total quartz & 0.12 & 0.05 & 0.06 & 0.02 & 0.04 & 0.04 \\
\hline $\begin{array}{l}\text { Plagioclase/Total feldspar } \\
\text { Volcanic Lithic fragments/ }\end{array}$ & 0.81 & 0.14 & 0.78 & 0.09 & 0.9 & 0.1 \\
\hline Total Lithic fragments & 0.32 & 0.11 & 0.02 & 0.13 & 0.4 & 0.1 \\
\hline
\end{tabular}


limestone layers that have yielded the mixed-age assemblages are carbonate turbidites, (Dumoulin and Miller, 1984); in these rocks, a mixed fauna may simply represent erosion of pelagic layers of different ages, and the age of the youngest fossil assemblage probably represents a maximum depositional age.

The middle and late Eocene fossil ages barely overlap or entirely postdate the emplacement age
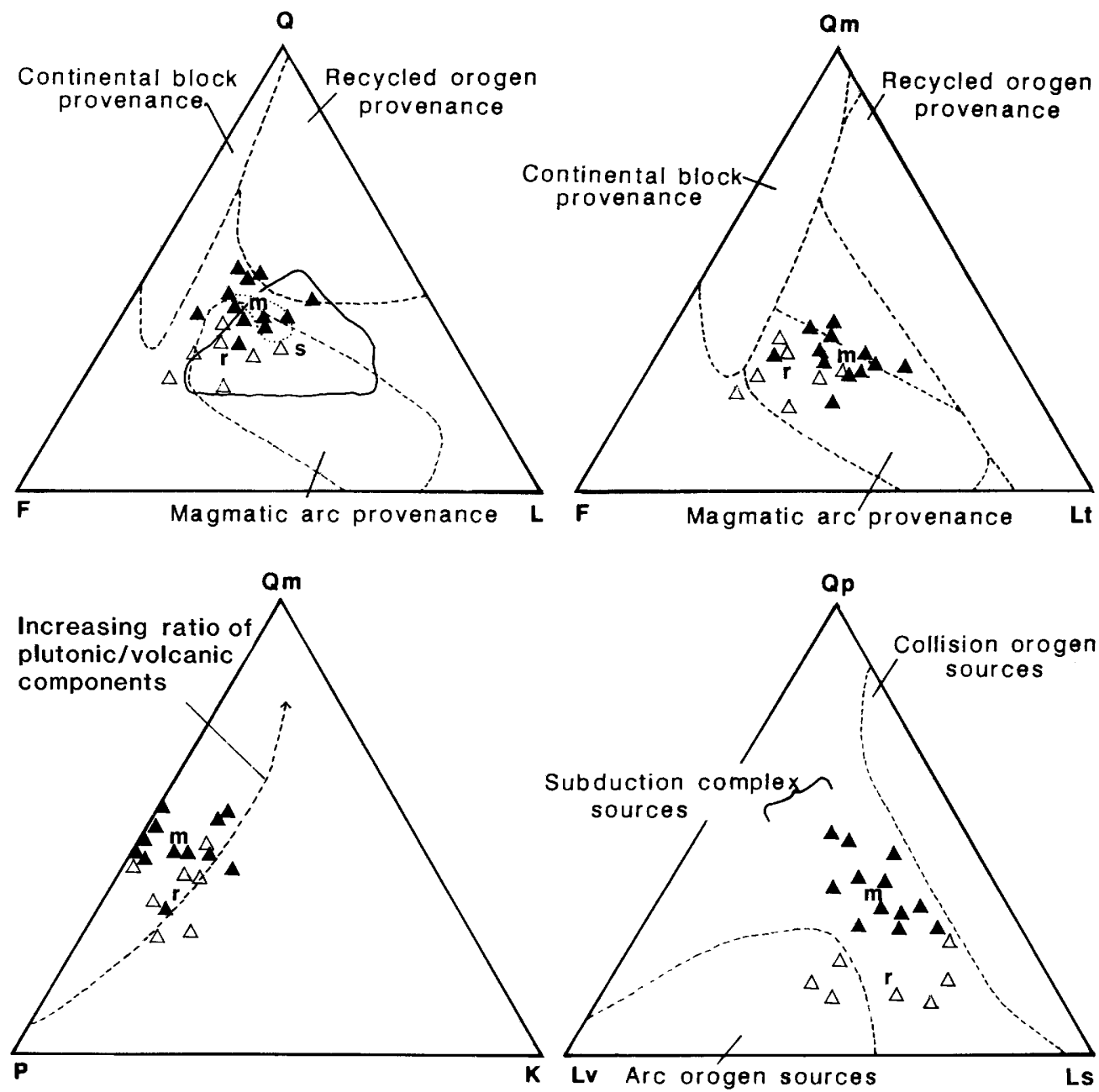

\section{EXPLANATION}

AREA MEAN

\section{CLAST TYPE}

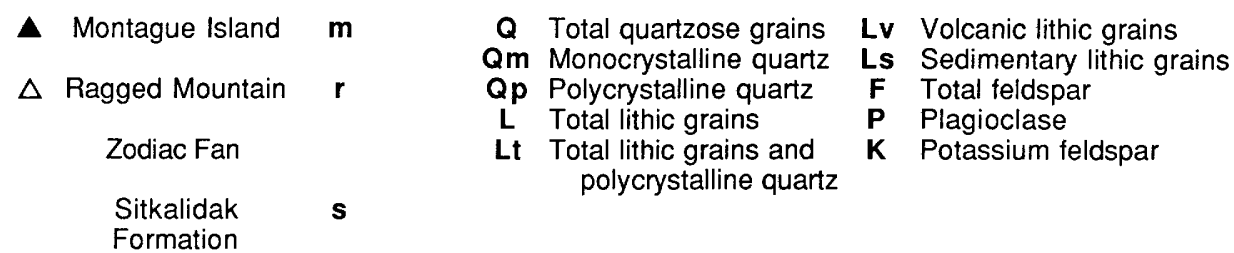

----- Provenance fields ${ }^{+}$

+ Dickinson and Suczek, 1979

Figure 17. - Modal analyses for sandstone of the Orca Group from the Montague Island and Ragged Mountain areas compared with analyses from the Zodiac fan (Stewart, 1976) and from the Sitkalidak Formation of Moore and Allwardt (1980), (Moore and others, 1983). 
range $(50.5-53.5 \pm 1.6 \mathrm{Ma})$ of the plutons that intrude the northern parts of the Orca Group. No plutons intrude rocks on Hinchinbrook or Montague Islands; a few small undated granite plugs intrude northwestern Ragged Mountain. The Rude River pluton, which intrudes the Orca Group northeast of, and apparently on strike with, the rocks of Hinchinbrook Island, is of late early or early middle Eocene age (Plafker and others, 1985b). However, the Rude River pluton is separated by more than $60 \mathrm{~km}$ and several laterally extensive faults from the nearest middle middle Eocene or younger fossil locality.

In summary, fossil data indicate that the rocks of Ragged Mountain and Hinchinbrook and Montague Islands are younger than the rest of the Orca Group. They may be younger than the early to earliest middle Eocene plutonic belt, but regional geologic relations complicate this interpretation. However, even if all the Orca Group were restricted to the early middle Eocene or older, present age constraints would allow its correlation, at least in part, with the Sitkalidak Formation and Zodiac fan sediments.

\section{Metamorphic-Grade Relationships}

The Montague Island-Ragged Mountain sandstone and Sitkalikdak Formation sandstone show similarities in their metamorphic grade relative to adjacent rocks. Tysdal and Case (1979) state that rocks east of the Montague Strait fault reach prehnite-pumpellyite and (or) zeolite grade, in contrast to the lowergreenschist-facies conditions west of the fault. However, rocks of Montague Island examined for this study appear to be mostly zeolite facies or lower, with local laumontite as veins and patchy alteration of feldspar. Only a few samples contain minor amounts of secondary pumpellyite (M.L. Miller, written commun., 1985). Prehnite-pumpellyite assemblages are extensively developed in the volcanic rocks of Hinchinbrook Island and Ragged Mountain, and it may be that well-developed prehnite-pumpellyite assemblages do not occur on Montague Island because of a lack of suitable host rocks (volcanic rocks or volcanic lithic-rich sedim entary rocks).

Vitrinite-reflectance values obtained from Montague, Green and Hinchinbrook Islands range from 0.8 to 1.27 (Helwig and Emmet, 1981), indicating minimum temperatures of about $150^{\circ}-200^{\circ} \mathrm{C}$ (Bostick, 1979). Values of 1.2 and 1.9 obtained from two samples from Point Martin, south of Ragged Mountain (Mull and Nelson, 1986) indicate minimum temperatures of $200^{\circ}-250^{\circ} \mathrm{C}$ (Bostick, 1979). The transition from zeolite to prehnite-pumpellyite facies is poorly constrained, but Turner (1981) suggested that it occurs at about $200^{\circ}-230^{\circ} \mathrm{C}$.

Vitrinite-reflectance values from the Sitkalidak Formation are slightly lower than those reported from the Montague Island and Ragged Mountain areas; they range from 0.55 to 0.61 and, along with porosity data, have been interpreted as defining a peak temperature of $100^{\circ}-125^{\circ} \mathrm{C}$, given an effective burial time of 5-20 m.y. (Moore and Allwardt, 1980). A minimum temperature of $125^{\circ} \mathrm{C}$ is obtained using the method of Bostick (1979). Laumontite occurs in some Sitkalidak sandstone samples (Moore and Allwardt, 1980).

The vitrinite-reflectance values from the Sitkalidak Formation are considerably less than those obtained from the Ghost Rocks Formation. The Ghost Rocks values range from 2.15 to 2.95 (Moore and others, 1983) and suggest a maximum temperature of $225^{\circ}-250^{\circ} \mathrm{C}$, given an effective burial time of $5-10$ m.y. Vitrinite reflectance data are not available for the northern and western parts of the Orca Group, but metamorphic-assemblage data indicate that, in general, metamorphic-grade increases to the north and west of the Montague and Ragged Mountain areas (M.L. Miller, written commun., 1985; Goldfarb and others, 1986).

Thus, the rocks of Montague and Hinchinbrook Islands and Ragged Mountain, like those of the Sitkalidak Formation, seem to have a somewhat lower metamorphic grade than the rocks directly adjacent to them. However, the rocks of the Orca Group have apparently reached slightly higher minimum temperatures than the Sitkalidak Formation.

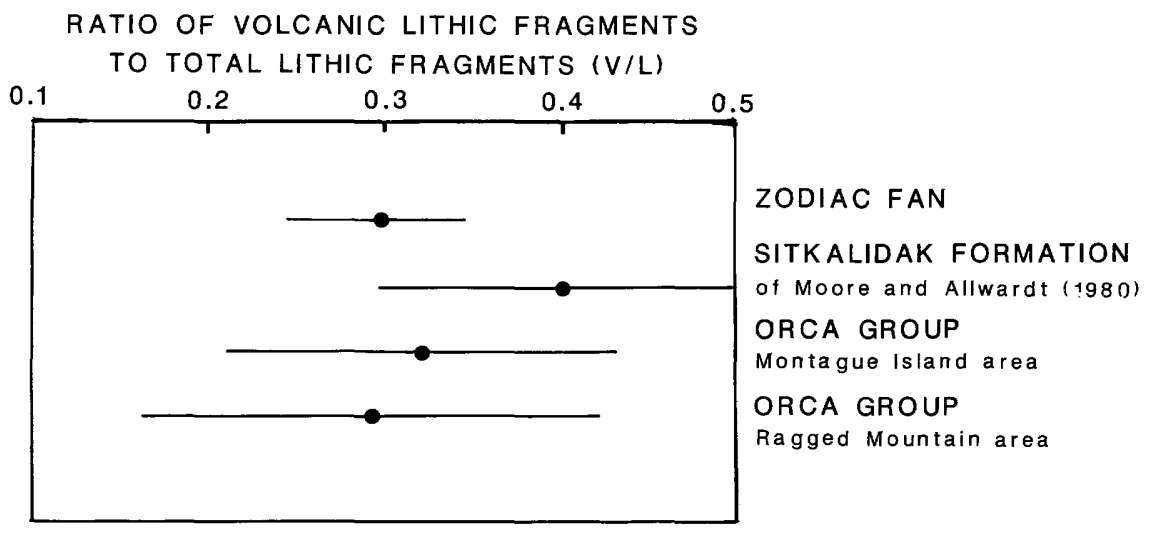

Figure 18. Ratio of volcanic clasts to total lithic fragments in Zodiac fan sediment (Stewart, 1976), Sitkalidak Formation sandstone (Moore and others,1983), and Orca Group sandstone from the Montague Island and Ragged Mountain areas. 
Structural Style

The structural style of the Orca Group on Montague and Hinchinbrook Islands is similar to that observed in the Sitkalidak Formation. Helwig and Emmet (1981) documented landward structural vergence in Montague-Hinchinbrook rocks and attributed its formation to obductive offscraping of a thick submarine-fan sequence deposited on a slowly descending plate decoupled on its landward side. Moore and Allwardt (1980) used a similar explanation for the extensive landward vergence in the eastern (more deformed) parts of the Sitkalidak Formation.

\section{$\underline{\text { Sedimentary Facies }}$}

Finally, sedimentary facies, known only from reconnaissance mapping of Montague Island and from more detailed mapping on Hinchinbrook Island (Winkler, 1976), are similar to those described from the Sitkalidak Formation by Nilsen and Moore (1979) and Moore and Allwardt (1980). In general, the less deformed parts of the Sitkalidak Formation consist of thin, relatively shale-rich, graded beds with local occurences of thick, massive sandstone. These sequences are interpreted as having been deposited on an outer fan, lobe fringe, and basin plain by Nilsen and Moore (1979). Moore and Allwardt (1980) suggested that this facies association constitutes a slope-basin or slope-apron deposit. Elsewhere, particularly in its more deformed parts, the Sitkalidak Formation consists of thicker bedded and coarser grained deposits (sandstone beds commonly 1-10 m thick) with local pebbly sandstone and conglomerate. These rocks are interpreted to be trench-filling inner- and middle-fan deposits (Moore and Allwardt, 1980).

The rocks of Montague and Hinchinbrook Islands consist largely of facies $\mathrm{C}$ and D turbidites (as defined by Mutti and Ricci-Lucci, 1978) in which sandstone and shale contents are roughly equal or shale is dominant. Local slurried sandstone beds with scattered argillite fragments are present; such beds were described by Nilsen and Moore (1979) in the Sitkalidak Formation and are typical of interlobe and lobe-fringe sequences. Calcite-cemented turbidites and calcareous concretions, also described from the Sitkalidak Formation, are common in the Montague and Hinchinbrook areas, especially in thinner bedded and more shale-rich sequences. Abundant coalified plant debris, noted in sandstone beds from the Sitkalidak Formation, is present in the MontagueHinchinbrook area as well.

Coarser grained, thicker bedded sandstone sequences also occur in the Montague-Hinchinbrook area; bed thicknesses exceed several meters, sandstone:shale ratios reach $20 / 1$, and intervals of conglomerate and pebbly mudstone with channelized bases occur locally. Such deposits are likely to represent inner- or middle-fan sequences.

\section{CONCLUSIONS}

Petrographic data from sandstones in the Prince William Sound area show no abrupt change across the
Contact fault, which juxtaposes the Upper Cretaceous Valdez Group and the Paleocene and Eocene Orca Group, and has also been suggested to represent the boundary between the Chugach and Prince William terranes. In the western part of Prince William Sound, sandstone compositions in both groups change systematically from west to east; however, graphical and statistical ${ }^{-}$analyses cannot discriminate sandstone of the easternmost exposures of the Valdez Group (central Valdez area) from that of the westernmost exposures of the Orca Group (Sargent Icefield area). Sandstone of both groups becomes gradationally richer eastward in quartz, potassium feldspar, and plagioclase, and gradationally poorer eastward in lathwork-textured volcanic clasts. In the eastern part of Prince William Sound, sandstone of the Valdez Group north of the Landlock segment of the Contact fault (Mount Denson area) cannot be differentiated from sandstone of the Orca Group south of this fault (Port Gravina-Cordova area).

The compositional data are best explained by considering the Valdez and Orca Groups as a single flysch sequence derived primarily from one continuously unroofing source-a magmatic arc progressively eroded from its volcanic cover to its plutonic roots through time. If a terrane boundary does exist in the Prince William Sound area, and if such a boundary coincides with a petrographic discontinuity, it may lie along the Jack Bay fault in eastern Prince William Sound, or perhaps farther north. In western Prince William Sound, the boundary is most likely to lie along the Bainbridge fault, $50 \mathrm{~km}$ east of the Contact fault. The Bainbridge fault separates quartz-rich rocks of the Knight Island area on the east from more feldspatholithic rocks of the Chenega area on the west.

The southeastern exposures of the Orca Group (Montague Island and Ragged Mountain areas, and perhaps the Hinchinbrook Island area as well) may constitute a distinct sequence of rocks, perhaps younger than the rest of the Orca Group. Rocks of the Montague Island area, in particular, show striking similarities to the Eocene Sitkalidak Formation of Moore and Allwardt (1980), $400 \mathrm{~km}$ to the west, as well as to the sediments of the Zodiac fan of the Aleutian abyssal plain.

\section{REFERENCES CITED}

Bostick, N.H., 1979, Microscopic measurement of the level of catagenesis of solid organic matter in sedimentary rocks to aid exploration for petroleum and to determine former burial temperatures-a review, p. 17-43, in Scholle, P.A. and Schluger, P.R., eds., Aspects of Diagenesis: Society of Economic Paleontologists and Mineralogists Special Publication No. 26, 443 p.

Burk, C.A., 1965, Geology of the Alaskan Peninsulaisland arc and continental margin: Geological Society of America Memoir 99, 250 p.

Capps, S.R., and Johnson, B.L., 1915, The Ellamar District, Alaska: U.S. Geological Survey Bulletin 605, 124 p. 
Condon, W.H., and Cass, J.T., 1958, Map of a part of the Prince William Sound area, Alaska, showing linear geologic features as shown on aerial photographs: U.S. Geological Survey Miscellaneous Geological Investigations Map I273 , scale $1: 125,000$.

Connelly, William, 1978, Uyak Complex, Kodiak Islands, Alaska-a Cretaceous subduction complex: Geological Society of America Bulletin, v. 89 , p. $755-769$.

Cowan, D.S., 1982, Geological evidence for post-40 Ma large-scale, northwestward displacement of part of southeastern Alaska: Geology, v. 10, no. 6, p. 309-313.

Cowan, D.S., and Boss, R.F., 1978, Tectonic framework of the southwestern Kenai Peninsula, Alaska: Geological Society of America Bulletin, v. 89 , p. 155-158.

Crook, K.A.W., 1960, Classification of arenites: American Journal of Science, v. 258, p. 419-428.

Decker, J.E., 1980, Geology of a Cretaceous subduction complex, western Chichagof Island, southeastern Alaska: Stanford, Cal., Ph.D. dissertation, Stanford University, $135 \mathrm{p}$.

Dickinson, W.R., 1970, Interpreting detrital modes of graywacke and arkose: Journal of Sedimentary Petrology, v. 40, p. 695-707.

Dickinson, W.R., and Suczek, C.A., 1979, Plate tectonics and sandstone compositions: American Association of Petroleum Geologists Bulletin, v. 63, p. 2164-2182.

Dumoulin, J.A., 1984, Composition and provenance of sandstone of the Orca and Valdez Groups, Prince William Sound, Alaska abs.: Geological Society of America Abstracts with Programs, v. 16, p. 280.

Dumoulin, J.A., and Miller, M.L., 1984, The Jeanie Point complex revisited, in Coonrad, W.L., and Elliot, R.L., eds., The United States Geological Survey in Alaska-Accomplishments during 1981: U.S. Geological Survey Circular 868, p. 75-77.

Folk, R.L., 1974, Petrology of Sedimentary Rocks: Austin, Texas, Hemphill Publishing Company, 182 p.

Goldfarb, R.J., Leach, D.L., Miller, M.L., and Pickthorn, W.J., 1986, Geology, metamorphic setting, and genetic constraints of epigenetic lode-gold mineralization within the Cretaceous Valdez Group, south-central Alaska, in Keppie, J.D., Boyle, R.W., and Haynes, S.J., eds., Turbidite-hosted gold deposits: Geological Association of Canada Special Paper 32, p. 87-105.

Grant, U.S., and Higgins, D.F., 1910, Reconnaissance of the geology and mineral resources of Prince William Sound, Alaska: U.S. Geological Survey Bulletin 443, 89 p.

Gromme, Sherman, and Hillhouse, J.W., 1981, Paleomagnetic evidence for northward movement of the Chugach terrane, southern and southeastern Alaska, in Albert, N.R.D., and Hudson, Travis, eds., The United States Geological Survey in Alaska-Accomplishments during 1979: U.S. Geological Survey Circular 823-B, p. B70-B72.

Helwig, James, and Emmet, Peter, 1981, Structure of the early Tertiary Orca Group, Prince William Sound, and some implications for the plate tectonic history of southern Alaska: Journal of the Alaska Geological Society, v. 1, p. 12-35.

Hillhouse, J.W., and Gromme, C.S., 1977, Paleomagnetic poles from sheeted dikes and pillow basalt of the Valdez(?) and Orca Groups, southern Alaska [abs.]: EOS, Transactions of the American Geophysical Union, v. 58, p. 1127.

Hollister, L.S., 1979, Metamorphism and crustal displacements-new insights: Episodes, v. 1979, p. 3-8.

Hudson, Travis, and Plafker, George, 1982, Paleogene metamorphism of an accretionary flysch terrane, eastern Gulf of Alaska: Geological Society of America Bulletin, v. 93, p. 1280-1290.

Ingersoll, R.V., Bullard, T.F., Ford, R.L., Grimm, J.P., Pickle, J.D. and Sares, S.W., 1984, The effect of grain size on detrital modes-a test of the GazziDickinson point-counting method: Journal of Sedimentary Petrology, v. 54, p. 103-116.

Ingersoll, R.V., and Suczek, C.A., 1984, Discussion of Early Proterozoic metasediments from northcentral Colorado-metamorphism, provenance, and tectonic setting, by K.C. Condie and Charles Martell, 1983, (in Geological Society of America Bulletin, v. 94, p. 1215-1224): Geological Society of America Bulletin, v. 95, p. 985.

Jones, D.L., and Clark, S.H.B., 1973, Upper Cretaceous (Maestrichtian) fossils from the Kenai-Chugach Mountains, Kodiak and Shumagin Islands, southern Alaska: U.S. Geological Survey Journal of Research, v. 1, p. 125-136.

Jones, D.L., Silberling, N.J., Berg, H.C., and Plafker, George, 1981, Map showing tectonostratigraphic terranes of Alaska, columnar sections, and summary description of terranes: U.S. Geological Survey Open-File Report 81-792, 20 p., 2 pls., scale $1: 2,500,000$.

Keller, Gerta, von Huene, Roland, McDougall, Kristin, and Bruns, T.R., 1984, Paleoclimatic evidence for Cenozoic migration of Alaskan terranes: Tectonics, v. 3, p. 473-495.

McGlasson, J.A., 1976, Geology of central Knight Island, Prince William Sound, Alaska: Golden, Colo., Colorado School of Mines, unpublished M. S. thesis, $136 \mathrm{p}$.

Mitchell, P.A., 1979, Geology of the Hope-Sunrise (gold) mining district, north-central Kenai Peninsula, Alaska: Stanford, Cal., Stanford University, unpublished M. S. thesis, 123 p.

Moffit, F.H., 1954, Geology of the Prince William Sound region, Alaska: U.S. Geological Survey Bulletin 989-E, p. 225-310.

Moore, J.C., 1973, Cretaceous continental margin sedimentation, southwestern Alaska: Geological Society of America Bulletin, v. 84, p. 595-614.

Moore, J.C., and Allwardt, Alan, 1980, Progressive deformation of a Tertiary trench slope, Kodiak Islands, Alaska: Journal of Geophysical Research, v. 85 , p. $4741-4756$.

Moore, J.C., Byrne, Tim, Plumley, P.W., Reid, Mary, Gibbons, Helen, and Coe, R.S., 1983, Paleogene evolution of the Kodiak Islands, Alaskaconsequences of ridge-trench interaction in a more southerly latitude: Tectonics, v. 2, p. 265293.

Mull, C.G., and Nelson, S.W., 1986, Anomalous thermal 
maturity data from the Orca Group (Paleocene and Eocene), Katalla-Kayak Island area, in Bartsch-Winkler, Susan, and Reed, K.M., eds., Geologic Studies in Alaska by the U.S. Geological Survey during 1985: U.S. Geological Survey Circular 978, p. 50-55.

Mutti, Emiliano, and Ricci Lucchi, Franco, 1978, Turbidites of the northern Apenninesintroduction to facies analysis: International Geology Review, v. 20, p. 125-166.

Nelson, S.W., Blome, C.D., Harris, A.H., Reed, K.M., and Wilson, F.H., 1986, Late Paoeozoic and Early Jurassic fossil ages from the McHugh Complex, in Bartsch-Winkler, Susan, and Reed, K.M., eds., Geologic Studies in Alaska by the U.S. Geological Survey during 1985: U.S. Geological Circular 978, p. 60-64.

Nelson, S.W., Dumoulin, J.A., and Miller, M.L., 1985 (1986), Geologic map of the Chugach National Forest, Alaska: U.S. Geological Survey Miscellaneous Field Studies Map MF-1645-B, 16 p., 1 pl., scale 1:250,000.

Nelson, S.W., Miller, M.L., Barnes, D.F., Dumoulin, J.A., Goldfarb, R.J., Koski, R.A., Mull, C.G., Pickthorn, W.J., Jansons, Uldis, Hoekzema, R.B., Kurtak, J.M., and Fechner, S.A., 1984, Mineral resource potential of the Chugach National Forest, Alaska: U. S. Geological Survey Miscellaneous Field Studies Map MF-1645-A, 24 p., 1 pl., scale 1:250,000.

Nie, H.H., Hull, C.H., Jenkins, J.G., Steinbrenner, Karin, and Bent, D.H., 1975, Statistical Package for the Social Sciences (2d ed.): New York, McGraw-Hill, Inc., 675 p.

Nilsen, T.H., and Moore, G.W., 1979, Reconnaissance study of Upper Cretaceous to Miocene stratigraphic units and sedimentary facies, Kodiak and adjacent islands, Alaska: U.S. Geological Survey Professional Paper 1039, $34 \mathrm{p}$.

Nilsen, T.H., and Zuffa, G.G., 1982, The Chugach terrane, a Cretaceous trench-fill deposit, southern Alaska, p. 213-227, in Legget, J.K., ed., Trenchforearc geology--Sedimentation and tectonics on modern and ancient active plate margins: London, Blackwells, $582 \mathrm{p}$.

Odum, J.E., 1975, Feldspar-grain size relations in Cambrian arenites, Upper Mississippi Valley: Journal of Sedimentary Petrology, v. 45, p. 636650.

Pavlis, T.L., 1982, Cretaceous deformation along the Border Ranges fault, southern Alaska-brittle deformation during formation of a convergent margin: Tectonics, v. 1, p. 343-368.

Pettijohn, F.J., Potter, P.E., and Siever, Raymond, 1973, Sand and Sandstone: New York, SpringerVerlag, $618 \mathrm{p}$.

Plafker, George, 1969, Tectonics of the March 27, 1964, Alaska earthquake: U.S. Geological Survey Professional Paper 543-I, p. I1-I74.

1971, Possible future petroleum resources of Pacific-margin Tertiary basin, Alaska, p. 120-135, in Cram, I.H., ed., Future petroleum provinces of North America: American Association of Petroleum Geologists, Memoir 15, 1496 p.

Plafker, George, and Lanphere, M.A., 1974, Radiometrically dated plutons cutting the Orca
Group, in U.S. Geological Survey Alaska Program, 1974: U.S. Geological Survey Circular 700, p. 53.

Plafker, George, Jones, D.L., and Pessagno, E.A., Jr., 1977, A Cretaceous accretionary flysch and melange terrane along the Gulf of Alaska margin, in Blean, K.M., ed., The United States Geological Survey in Alaska--Accomplishments during 1976: U.S. Geological Survey Circular 751-B, p. B41B43.

Plafker, George, Keller, Gerta, Barron, J.A., and Blueford, J.R., 1985a, Paleontologic data on the age of the Orca group, Alaska: U.S. Geological Survey Open-File Report 85-429, 24 p.

Plafker, George, Keller, Gerta, Nelson, S.W., Dumoulin, J.A., and Miller, M.L., 1985b, Summary of data on the age of the Orca Group, in BartschWinkler, S.W., ed., The United States Geological Survey in Alaska-Accomplishments during 1984: U.S. Geological Survey Circular 967, p. 74-76.

Plafker, George, and MacNeil, F.S., 1966, Stratigraphic significance of Tertiary fossils from the Orca Group in the Prince William Sound region, Alaska, in Geological Survey Research 1966, Chapter B: U.S. Geological Survey Professional Paper 550-B, p. B62-B68.

Plumley, P.W., Coe, R.S., and Byrne, Tim, 1983, Paleomagnetism of the Paleocene Ghost Rocks Formation, Prince William terrane, Alaska: Tectonics, v. 2, p. 295-314.

Plumley, P.W., and Plafker, George, 1985, Additional estimate of paleolatitude for the Paleocene/Eocene (?) Prince William TerraneOrca volcanics [abs.]: Geological Society of America Abstracts with Programs, v. 17, p. 401.

Silberling, N.J., and Jones, D.L., 1984, Lithotectonic terrane maps of the North American Cordillera: U.S. Geological Survey Open-File Report 84-523, 106 p., 4 pl., scale $1: 2,500,000$.

Sisson, V.B., Hollister, L.S., and Plafker, George, 1986, Rapid two-stage metamorphism of the eastern Chugach Mountains. [abs]: Geological Society of America, Abstracts with Programs, v. 18, p. 186.

Stewart, R.J., 1976, Turbidites of the Aleutian abyssal plain-- mineralogy, provenance, and constraints for Cenozoic motion of the Pacific Plate: Geological Society of America Bulletin, v. 87, p. 793-808.

Stone, D.B., Panuska, B.C., and Packer, D.R., 1982, Paleolatitudes versus time for southern Alaska: Journal of Geophysical Research, v. 87, p. 36973707.

Turner, F.J., 1981, Metamorphic PetrologyMinerological, Field and Tectonic Aspects (2d Ed.): Washington, Hemisphere Publishing Corporation, 524 p.

Tysdal, R.G. and Case, J.E., 1979, Geologic map of the Seward and Blying Sound quadrangles, Alaska: U.S. Geological Survey Miscellaneous Geologic Investigation Series Map I-1150, 12 p., 1 pl., scale $1: 250,000$.

Tysdal, R.G., Case, J.E., Winkler, G.R., and Clark, S.H.B., 1977, Sheeted dikes, gabbro, and pillow basalt in flysch of coastal southern Alaska: Geology, v. 5, p. 377-383.

Valloni, Renzo, and Maynard, J.B., 1981, Detrital modes of recent deep-sea sands and their relation 
to tectonic setting--a first approximation: Sedimentology, v. 28, p. 75-83.

Winkler, G.R., 1976, Deep-sea fan deposition of the lower Tertiary Orca Group, eastern Prince William Sound, Alaska, in Miller, T.P., ed., Recent and ancient sedimentary environments in Alaska: Anchorage, Alaska Geological Society, Symposium Proceedings, p. R1-R20.

Winkler, G.R., Miller, M.L., Hoekzema, R.B., and Dumoulin, J.A., 1984, Guide to the bedrock geology of a traverse of the Chugach Mountains from Anchorage to Cape Resurrection: Anchorage, Alaska Geological Society, 40 p.

Winkler, G.R. and Plafker, George, 1975, The Landlock fault-part of a major early Tertiary plate boundary in southern Alaska, in Yount, M.E., ed.: U.S. Geological Survey Alaska Program, 1975: U.S. Geological Survey Circular 722, p. 49.

Winkler, G.R., and Plafker, George, 1981, Geologic map and cross sections of the Cordova and Middleton Island quadrangles, southern Alaska: U.S. Geological Survey Open-File Report 81-1164, 26 p., 1 pl.,scale 1:250,000.

Zuffa, G.G., Nilsen, T.H., and Winkler, G.R., 1980, Rock-fragment petrography of the Upper Cretaceous Chugach terrane, southern Alaska: U.S. Geological Survey Open-File Report 80-713, $28 \mathrm{p}$. 


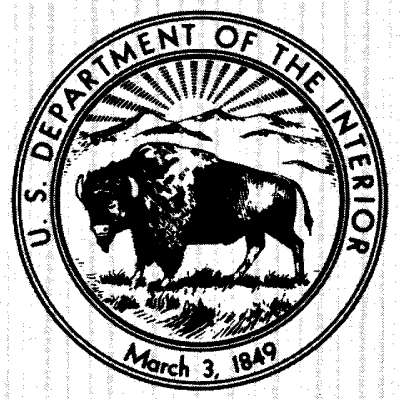

